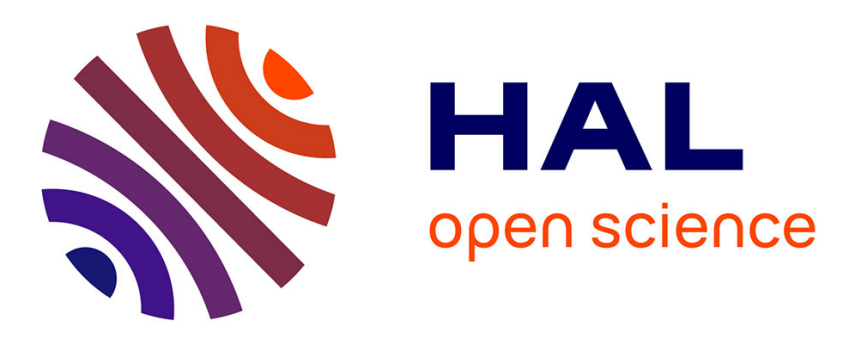

\title{
Treatment decision-making in chronic diseases: What are the family members' roles, needs and attitudes? A systematic review
}

Kristopher Lamore, Lucile Montalescot, Aurélie Untas

\section{- To cite this version:}

Kristopher Lamore, Lucile Montalescot, Aurélie Untas. Treatment decision-making in chronic diseases: What are the family members' roles, needs and attitudes? A systematic review. Patient Education and Counseling, 2017, 100 (12), pp.2172-2181. 10.1016/j.pec.2017.08.003 . hal-03058851

\section{HAL Id: hal-03058851 https://hal.science/hal-03058851}

Submitted on 11 Dec 2020

HAL is a multi-disciplinary open access archive for the deposit and dissemination of scientific research documents, whether they are published or not. The documents may come from teaching and research institutions in France or abroad, or from public or private research centers.
L'archive ouverte pluridisciplinaire HAL, est destinée au dépôt et à la diffusion de documents scientifiques de niveau recherche, publiés ou non, émanant des établissements d'enseignement et de recherche français ou étrangers, des laboratoires publics ou privés. 


\section{Treatment decision-making in chronic diseases: What are the family members' roles, needs and attitudes? A systematic review}

Kristopher Lamore ${ }^{\mathrm{a} *}$, Lucile Montalescot $^{\mathrm{a} *}$, Aurélie Untas ${ }^{\mathrm{a}}$

a - Laboratory of psychopathology and health processes (EA 4057), University of Paris Descartes Sorbonne Paris Cité, 71, avenue Edouard-Vaillant, 92100, Boulogne-Billancourt, France

*Co-first author

Corresponding author:

Kristopher Lamore, kristopher.lamore@gmail.com, Tel: +33647845573

E-mail addresses:

Kristopher Lamore: kristopher.lamore@gmail.com

Lucile Montalescot: lucile.montalescot@gmail.com

Aurélie Untas: aurelie.untas@parisdescartes.fr 


\title{
Treatment decision-making in chronic diseases: What are the family members' roles, needs and attitudes? A systematic review
}

\begin{abstract}
Objective: This systematic review aims to examine the roles of family members (FMs) in treatment decision-making for adult patients without cognitive or psychiatric disorders affecting their ability to participate in decision-making.
\end{abstract}

Methodology: A comprehensive, systematic search of the Cochrane Library, PsycINFO, PubMed and ScienceDirect databases, with relevant keywords, was conducted. Two authors evaluated the eligibility of the studies independently, then cross-checked for accuracy. The quality of included studies were assessed using standardized criteria.

Results: Out of the 12137 studies identified, 40 were included. Results highlighted the different roles and influences FMs have in the decision-making process. Moreover, several factors ranging from personal to cultural and family-related factors influence their level of involvement. Regardless of the illness, some similarities in family influence exist (e.g., social support). However, the type of family involvement varies according to the illness, the treatment choice and the patients' culture.

Conclusion: FMs have an important role in the decision-making process. In fact, the final decision is often made by the patients after consulting their families. FMs can support both patients and medical teams, and thus facilitate the process.

Practice implications: Physicians should include FMs in treatment decision-making when the patients and their FMs wish to be included.

Key-words: caregiver; decision-making; family; illness; partner; relatives; review; treatment choice. 


\section{Introduction}

In chronic and serious diseases (e.g., cancer, multiple sclerosis) multiple treatments may be available (e.g., surgery, transplantation) and thus a choice needs to be made. Historically, and for a long time, physicians were the ones who made the decisions [1]. However, with the emergence of patient-centered care in the $21^{\text {st }}$ century, patients are more involved in decisions regarding their own health, especially in life-threatening illnesses [2,3]. Moreover, patient involvement in treatment decision-making contributes to improved satisfaction with care and patient autonomy [3,4]. This active patient involvement in treatment decisions is often referred to as shared decision-making. This concept has been defined by Charles et al. [5] as a process between patients and their physicians whereby they share information, express their treatment preferences and make a decision by mutual agreement. However, Berry [6] and Towle et al. [7] highlighted the physicians' difficulties to reach shared treatment decisions (e.g., communication difficulties). Moreover, some physicians may be reluctant to proceed to shared decision-making because of their understanding of their professional role or their preferred decision-making process as a provider [8]. These difficulties in reaching a shared decision are experienced by both patients and physicians. Patients tend to follow the physicians' decisions $[9,10]$, thereby they may increase the physicians' burden and stress in specific situations [11]. Moreover, treatment decision-making is also a stressful time for patients [12].

Most authors only recognize two actors in the shared decision-making process, the patients and their physicians [1]. Indeed, within the scope of shared decision-making, research has mostly focused on the patients' individual factors and/or the patient-physician relationship factors. However, Charles et al. [1] discussed briefly the potential involvement of family members (FMs) during the deliberation phase (i.e., discussion of advantages/disadvantages of each treatment option) of the shared decision-making process. Nevertheless, the authors do 
not mention the role FMs could have during other stages of the decision-making process, nor do they state what specific roles they can have.

However, in the last decade, scientific literature has begun to focus on the role of FMs in chronic diseases, addressing the limits of shared decision-making models focusing only on patient-physician interactions. FMs often accompany patients during their consultations [13] and are involved in discussions regarding treatment choices [14]. Indeed, the majority of patients, FMs and physicians prefer the families to be involved in treatment decision-making, to some extent [15-17]. However, family involvement is a more recent development compared to dyadic (patient-physician) approaches in which the FMs' role is rarely acknowledged. To date, two systematic reviews and a meta-ethnography $[9,10,18]$ have been conducted on family involvement in treatment decision-making. They highlight the different roles FMs and friends take on during this process, as well as their experiences. However, these studies were conducted on specific diseases (i.e., cancer, chronic kidney disease) or specific circumstances (e.g., FMs' roles in medical consultations). Little is known about chronic illnesses in general and who/when FMs take part in treatment decision-making.

Therefore, the present systematic review aims to explore the roles of FMs in treatment decision-making when patients are adults and are able to partake in the discussions regarding their treatments. By identifying precisely how and when FMs can help in treatment decisionmaking, we hope to highlight the importance of FMs in this process and the similarities and differences in family involvement, depending on the context (i.e., the disease, the treatment and the relationship with the patient).

\section{Methodology}

Our methods followed the guidelines described by the Preferred Reporting Items for Systematic Reviews and Meta-Analysis (PRISMA) [19]. 


\subsection{Search strategy and eligibility}

We used the most relevant international databases for our objective (i.e., the Cochrane Library, PubMed, PsycINFO and ScienceDirect) to conduct a systematic literature review. Our research included articles written in English or in French and published up to October 28th, 2016. A list of search terms was developed by considering the research objective and studying relevant review articles. First, the databases were interrogated using the following key-words (see Box 1). The equation used on PubMed database is proposed in Box 2. Then, the reference lists of the included articles and grey literature were also investigated.

Studies using a qualitative, quantitative or mixed design were included if they satisfied the following criteria: (a) investigated a treatment decision-making (except prevention); (b) were conducted on patients aged 18 and over capable to participate in the decision-making (thus, we did not include patients with dementia or psychosis) and diagnosed with a chronic illness according to the National Center for Health Statistics [20]; (c) investigated family involvement in the decision-making (i.e., when patients need to choose between several treatments) whether FMs were interrogated or not. Only primary research articles published in peer-reviewed journals were included. As the definition of FMs differs in the literature, we considered FMs as people forming a socioemotional unit (including spouses, parents-in-law and friends).

Insert « Box 1 and 2 »

\subsection{Data extraction}

Data extraction was divided into two parts. First, titles and abstracts were screened to identify potentially eligible studies. To be eligible, titles and/or abstracts had to mention chronic illness and/or treatment choice and/or family/caregivers and/or healthcare trajectories. Secondly, full texts of potentially eligible studies were investigated. Then, a final list of eligible studies was established. This procedure was followed by two researchers independently (KL and LM) and discussed with the study 
coordinator (AU) in case of disagreement, to reach a consensus. When necessary, the corresponding authors of the selected articles were contacted for additional information or to obtain the manuscript in its final version (due to an inaccessible version on the database). EndNote $X 7.7{ }^{\circledR}$ reference manager was used to detect duplicates. Both investigators (KL and $\mathrm{LM}$ ) created a table with the following information on the selected studies: authors, year, country, study design and methods, population (sample sizes and characteristics, recruitment locations, type of treatment choices), objective(s), measure(s) and main results. Finally, the findings were examined using a narrative method [21]. This method allows researchers to synthetize the information narratively by gathering the studies' findings. According to this organization, a preliminary list of themes was created by gathering similar findings together (quantitative and/or qualitative). Then, the list was discussed by the authors to organize the findings into major themes.

\subsection{Quality assessment}

The "quality assessment tool" (QATSDD) [22] was used to assess the methodological quality of the included studies whether qualitative, quantitative, or mixed designs. The QATSDD is composed of 16 items for mixed methodology (with 2 items specific to quantitative designs and 2 items specific to qualitative designs) ranging from 0 to 3 for each item ("not at all" to "complete"). It allows for a comparison between the diverse methodologies used by providing a mean score. This recent method was selected for its reliability and validity when assessing the quality of diverse study designs. The QATSDD is also the only tool which can be applied to mixed designs. This assessment includes for example the study's theoretical framework and its description of the research settings.

Both investigators (KL and $\mathrm{LM}$ ) assessed together the quality of the included studies using the QATSDD. Any discrepancy was discussed, and a consensus was reached.

\section{Results}

Out of the 12137 articles screened, we included 40 studies (26 qualitative, 11 quantitative and 3 mixed designs). The excluded studies were not relevant for the present study: they investigated treatment decisions in non-autonomous patients (e.g., children) or only from the medical point of view (e.g., 
description of treatments). Figure 1 presents a flow-diagram of research articles as proposed by PRISMA [19].

Insert « Figure 1 »

\subsection{Study characteristics and quality assessment of the included studies}

The included studies were conducted between 1999 and 2016, with a majority of articles published between 2010 and $2016 \quad(n=28) \quad[16,23-49], \quad$ in North America $\quad(n=19)$ $[23,26,27,30,34,35,50,43,45,46,48,50-57]$ and Europe (n=9) [12,25,28,29,31,33,44,49,59]. The included 40 studies comprised cross-sectional studies $(\mathrm{n}=36)$ [12,16,23-41,43,45-47,49-51,53-60], retrospective studies $(\mathrm{n}=24)[12,23,24,26,27,29-31,33,35,37,38,40-42,45-47,50,53,55-58] \quad$ and longitudinal studies $(n=8)[23,31,34,44,48,49,52,59]$. The characteristics regarding the countries of publication, populations, decision-making subjects, designs and participants are presented in Table 1 . Furthermore, most of the included studies were of moderate quality (mean $=50 \%$, ranging from $31 \%$ to $71 \%$ ), as presented in Appendix 1 and 2.

The examination of the included studies revealed five major themes: (1) types of family influence, (2) FMs' roles, (3) factors contributing to family implication, (4) family needs and preferences and (5) decision-making patterns. These results are common among most treatment decision-making contexts (e.g., illness, decision-making subject) included in this review. Therefore, the results are presented in a general manner except when family involvement was specific to the decision context. The studies' characteristics and results are presented in Appendix 3.

Insert « Table 1 »

\subsection{Theme 1: Roles of the family}

Twenty-five studies explored the roles of FMs during treatment decision-making [24,25,27,29-33,35$38,40-43,46,47,50,51,53,56,58,60]$. We identified 4 sub-themes: role of social support, role of intermediary between the patient and the physician, role of collaborator and role of messenger.

\subsubsection{Family members as source of social support}

Fifteen studies identified FMs as important helpers in treatment decision-making [25,27,28,30,33,35- 
$38,40,41,43,46,56,58]$. They can provide emotional, informational and esteem support.

Informational support was the most common support provided by FMs (14 studies) [25,27,28,33,35$38,40-42,43,47,56]$. FMs tended to summarize the information given by the physicians to the patients and repeat it [37,38]. Furthermore, FMs filtered information on the treatments which were not consistent with the patients' or the families' wishes, so as not to overwhelm the patients $[43,47]$.

The second most reported type of support provided by FMs was emotional support (10 studies) [30,36$38,40,42,43,46,56,58]$. FMs created a "safe place" for the patients by simply "being there" $[38,56]$. They provided physical support (e.g., hand holding) and reassuring comments regarding the decision $[38,42]$.

Furthermore, FMs could provide esteem support by showing confidence in the patients' ability to make the right decision [37].

Finally, the support provided by FMs may reduce the patients' burden and their uncertainty in treatment decision-making [30].

\subsubsection{Family members as intermediaries between the patient and the physician}

Thirteen studies explained that FMs could help the communication between the physicians and the patients $[24,30,32,36,40-42,47,50,51,53,56,58]$. They serve as-advocates for the patients, intermediaries between the patients and the physicians or translators.

First, FMs could be active patient advocates. They could defend the patients' interests, give useful information (e.g., medical histories) and ask questions to know more about the treatments (e.g., alternatives, potential benefits/consequences) [36,41,42,50,51,53]. This role highlights a strong patient-family coalition [50].

Secondly, when FMs acted as intermediaries, they relayed the patients' questions/concerns to the physicians and vice versa [41] or helped during the consultations when the patients were distressed [42]. FMs could also act as the patients' "representatives" and make the decision on their behalves $[24,32,46,50,56]$. They then became the first interlocutors of the medical teams. 
Finally, FMs could act as translators for the patients, allowing the latter to better interact with physicians despite the language barrier [30,40,47,58].

\subsubsection{Family members as collaborators}

This role was found in 13 studies [27,29-31,35-38,40,41,43,51,56] and was reported by patients, families and physicians. FMs collaborated with the patients during the decision-making process by sharing thoughts/ideas, by participating in the discussions $[30,40]$ or by acting as sounding boards for the patients $[31,35,37,40,56]$. Some patients and FMs used the words "we"/“our" to talk about the disease and/or the treatment choice $[29,31,35,40]$. Patients and FMs worked as co-decision makers during the decision-making process $[38,41,43,56]$.

\subsubsection{Family members as messengers}

Laidsaar-Powell et al. [38] reported that FMs attending medical consultations could act as messengers to the extended family. They shared the information they got during the consultation and defended the patients' choices. This role can be stressful for FMs and a potential source of family conflict.

\subsection{Theme 2: Types of family influence}

Twenty-five studies $[12,25,26,28-32,35-38,40-42,43,47,50,51,53,56-60]$ reported the types of family influence. Two sub-themes emerged: how and when FMs influence decision-making.

\subsubsection{How family members influence decision-making}

Different influences and attitudes were reported: direct or indirect influence, positive or negative influence, and passive to dominant attitude. The following definitions are based on our analysis of the data.

\subsubsection{Direct or indirect influence}

Twenty-two studies discussed the direct $(n=20)$ and/or indirect $(n=9)$ influence of families $[12,25,26,28-30,32,35-37,40-42,45,47,50,51,53,56-58,60]$.

A direct influence refers to a specific or observable behavior which influences the flow of decisionmaking and/or its outcomes. It includes behaviors such as: giving opinions about the treatments 
$[30,35-37,60]$ and which physician to see $[37,50]$, encouraging the patients to consider their families' opinion during the decision-making [30,41], persuading the patients to make a certain decision $[42,45,56]$, offering to donate a kidney in renal failure [59], and acting as intermediaries between the patients and the physicians $[32,40,47,53,58]$.

On the contrary, an indirect influence does not refer to any specific behavior. Patients are influenced by their families just "being there". More precisely, patients considered the potential impact of the treatment on their families to make their decisions $[12,29,40,41,53,56,57,60]$. They opted for a certain treatment after considering their family medical history [53] or because of their concerns [41] and obligations toward their families $[12,45]$.

\subsubsection{Positive or negative influence}

Patients, families and physicians reported the FMs' positive $(n=16)$ or negative $(n=12)$ influence $(16$ studies) $[30,35-38,40-42,45,50,51,53,56,57,59,60]$. This refers to the patients', FMs' and physicians' perceptions of the impact of family involvement on the decision-making process.

A positive influence refers to the patients' appreciation of their families' involvement in decisionmaking $[37,38,41,60]$ and when FMs are perceived as being helpful $[30,37,38,41,53,57]$. The FMs' involvement contributed to reinforcing their relationship with the patients and reducing the patients' anxiety in treatment decision-making [56]. In addition, FMs contributed to protect the patients' autonomy [37,51] and rights [42]. Patients reported that family involvement tended to improve their relationship with their physicians (e.g., physicians give more information when FMs attend the consultation) [30,59]. Positive influence is also linked to the FMs' role [30,35-38,40$42,50,51,53,56,60]$.

Conversely, family influence is deemed negative when FMs interfere with the decision-making process, with for example a negative attitude (e.g., pressuring the patients), [35-38,51,53,60], a dominant attitude (perceived negatively by physicians) [37,51], a change of attitude [53], or when they overwhelm the patients with information [56], or when the patients think of a FM's medical history (e.g., a FM died of cancer despite chemotherapy) [53]. Furthermore, the FMs' presence during the 
consultations could generate tensions $[38,56]$ or prevented the patients from talking about certain subjects (e.g., sexuality) [38]. In some cases, when FMs were the first interlocutors of the medical staff, it could prevent the patients from fully understanding the decision-making [40,50].

\subsubsection{Passive to dominant attitude}

The FMs' behaviors during the decision-making process can be conceptualized as a continuum from a passive $(n=5)$ to an active $(n=9)$ or even a dominant attitude $(n=6)$, as reported in nine studies $[25,31,35-38,50,51,56]$. A passive attitude refers to FMs who are not involved in the decision-making $[37,38]$, do not share their opinion [36] or do not want to be involved for specific reasons (e.g., lack of medical knowledge) [35]. The FMs' attitude is deemed active when they ask questions [35,36,50], explain/inform the patients about the treatments or have a collaborative role in the decision-making process $[36,50,51,56]$. More rarely, FMs can have a dominant attitude by taking charge of the decision-making process $[31,36,37,56]$ or having autonomy-detracting behaviors (e.g., answering for the patients) [51]. This attitude was generally perceived positively by patients $[31,36,37,56]$, while the physicians perceived this dominant attitude negatively [37,51]. If patients were passive during the decision-making, FMs had a more active/dominant role $[25,31,38]$.

\subsubsection{When family members influence the decision-making}

Eleven studies discussed family influence during different stages [30,31,35-38,40,42,50,51,58]: before, during and after the consultation with a physician.

First, FMs could influence patients before the consultations by advising them to undergo medical tests [50,58] or choose a certain physician or hospital $[37,40,42]$. Thus, FMs could influence patients even before any treatment decision needed to be made. To clarify their role, they could discuss with the patients what behavior they should adopt to be helpful [38]. Secondly, FMs could take an active role during medical appointments, allowing the patients to make decisions independently [30].

Consultations could be divided in 3 sub-stages: information exchange, deliberation and decisionmaking, as presented by Charles et al. [1,5] (only Laidsaar-Powell et al. [36] refer to this definition). FMs were involved during the exchange of information, both with the patients and the clinicians. They 
provided support to the patients [30,31,35-38,40,42,50,51,58]. During the exchanges with the physicians, FMs could act as intermediaries [31,36,37,42,51], resulting in an improvement in the quality and the quantity of information shared [31]. FMs could then be involved in the deliberation. In this sub-stage, few FMs expressed their opinion or dominated the discussion [36-38]. They mainly supported the patients' decisions [31,38]. They could also act as sounding boards for the patients [35,36,38]. Finally, FMs are not involved in the decision-making phase (i.e., when the patient formulates his/her decision) $[30,35,36,37,42,43,56]$ but they influence the patient's choice $[30,31,36$ $38,42,45,56]$ and can deliberate about the decision before with the patient $[31,36]$.

After the consultations FMs could keep discussing the decision, recall or obtain information $[31,35,37,38]$. The FMs' attitudes could also be discussed after the consultations with the patients to identify helpful and unhelpful behaviors [38]. During this stage, patients and FMs could express their preferences/feelings. Patients could change their minds or seek a second opinion $[31,35,37]$.

\subsection{Theme 3: Factors contributing to family involvement}

Twenty-nine studies $\quad[12,16,24,25,27,29,30,32,35,37-39,40-42,44,46-53,55-58,60]$ highlighted the facilitators and barriers to family involvement. These factors also contribute to the role and the type of family influence.

\subsubsection{Illness factors}

Depending on the illness, the type of influence could vary. In chronic kidney disease it appeared that indirect influence was much more studied and reported by researchers than in other diseases $[12,29,57,60]$. In particular, when patients considered or chose in-center hemodialysis, indirect influence was often reported $[12,57,60]$. In breast cancer, most patients came to the consultations with a FM $[39,48,53]$. The most reported type of influence was direct influence $[40,53,56]$. In fact, FMs could have a collaborative role $[25,48,56]$ and provide emotional and informational support $[40,56]$. Patients reported both (mostly direct) positive influence and (both direct and indirect) negative influence $[53,56]$.

\subsubsection{Patients factors}


Family involvement in the decision-making was modulated by the patients' individual factors, as reported in 12 studies [16,24,30,37,38,44,46,48-50,52,56]. FMs were more involved in the decisionmaking when the patients were of a young age or elderly [16,24,30,37,38,46,48,49,52], women [49], when they were difficult to contact by the medical team [50], or lacked medical knowledge [44,56]. In these cases, family influence was direct.

\subsubsection{Family factors}

Seven studies [16,37,38,51,52,55,56] reported individual and relationship factors related to the involvement of FMs in the decision-making. First, FMs involved in the decision-making were commonly educated middle-aged women with good medical knowledge. Secondly, FMs tended to be more involved when they had a strong relationship with the patients $[16,52,56]$ or when the decision impacted them (e.g., sexuality) [55]. Spouses, parents and children were more involved in treatment decision-making, compared to other FMs [37,38,51].

\subsubsection{Cultural factors}

Twelve studies reported that FMs were more involved in the decision-making process when the patients were from a different culture or did not speak the same language as the physician $[16,24,30,32,37,38,40-42,47,48,58]$. FMs usually acted as translators $[30,40,47,58]$ and could struggle to translate medical terminology [47]. Cultural specificities exist: Hispanic patients were more likely to be helped by a parent, a child or a grandchild, while Asian patients were more likely to be helped by their partners $[40,48]$. Moreover, in studies carried out with Asian patients, FMs were often involved in treatment decision-making [16,24,32,41]: they influenced greatly, both directly [40-42] and indirectly, the patients' choices [40,41].

\subsubsection{Medical factors}

Twelve studies addressed this subtheme $[24,25,27,30,37,38,40-42,44,50,51]$. Physicians could request the FMs' advice when a patient was too physically/mentally unwell $[36-38,44,50]$. FMs were more involved with sicker patients [51]. Furthermore, the degree of family involvement fluctuated depending on the different stages of the patients' care (e.g., first decision, end-of-life decision) 
[24,37]. When surgery was a treatment option, FMs provided a lot of informational support to the patients $[25,27,40-42]$ and adopted a very active attitude in the decision-making process $[25,30,40,42]$.

\subsubsection{Barriers to family members' involvement}

Four studies reported barriers to family involvement in treatment decision-making $[16,35,37,40]$. These barriers include: the FMs' lack of medical knowledge [35,40], poor fluency in English, distance, work responsibilities [40], and higher patient education or medical knowledge [16,37]. Furthermore, FMs did not want to participate in decision-making when they were 'scared' of the illness and its consequences [35].

\subsection{Theme 4: Family needs and preferences}

Nine studies listed the FMs' needs during the decision-making process [16,23,26,32,33,35,54,55,58]. They were divided into two sub-themes: need for information and need to be involved. These needs are similar to the patients' $[23,28,32,37,47,53,54,58,59]$.

\subsubsection{Need for information}

The main need expressed by FMs was a need for information (5 studies) [23,26,32,33,54]. FMs desired more information in 7 domains: treatments [23,26,32], outcomes/complications of the treatments $[23,26,32]$, prognosis $[23,33]$, impact of the treatment on the patient and family's lifestyle [23,54], financial impact and technical knowledge regarding the treatment [23]. For FMs, this knowledge allowed them to help the patient better. However, to be efficient, the information given must not exceed their memory, understanding and psychological capacity [23].

\subsubsection{Need to be involved}

Some FMs expressed a need to be involved in the decision-making process (5 studies) $[16,32,35,55,58]$. They wanted to participate in the consultations [58] and the discussions about the treatment decision $[16,32,35,55]$. Being involved could allow them to discuss treatment choices with the patients more efficiently $[32,58]$. FMs wanted to be involved in the discussions with the physician because the disease and treatments would affect them too. They wanted to be taken seriously, to be listened to and have their expertise of the patient recognized by the physicians $[55,58]$. FMs wished to 
share some of the rights and responsibilities associated with decision-making [35]. However, two studies [32,33] highlighted some FMs' preference not to be the decision makers, so as not to feel guilty. The final choice belonged to the patients $[30,35,36,42,43,56]$.

\subsection{Theme 5: Decision-making patterns}

"Patterns" of decision-making emerged in 17 studies [23,32,34-36,38-40,43,44,47,50-52,54,56,58]. FMs could be excluded or included in treatment decision-making. We propose potential decisionmaking patterns. However, the patterns are not clearly defined in the studies.

\subsubsection{Family members' exclusion from decision-making}

FMs could be excluded from decision-making by both patients and physicians (reported in 15 studies) [23,34$36,38,40,43,44,47,50-52,54,56,58]$. First, the decision could be made by the physicians only. Patients could defer the decision to the physicians $[23,34,47,50,52]$, when they trusted them $[34,40]$. Physicians could also dominate the decision-making [44,51]. Secondly, the decision could be made by the physicians and the patients. A patient-physician coalition could contribute to exclude FMs from the decision-making [50]. Some patients did not want to involve their families in this process (e.g., disease hidden from FMs) $[34,35,43,47,54,56]$. The physicians' attitude toward FMs could also be inclusive/exclusive [36,38,58]. In some cases FMs had to make an effort to be included [58].

\subsubsection{Family members' inclusion in decision-making}

Five studies discussed patterns where FMs were included in treatment decision-making $[32,34,39,50,54]$. First, treatment choice could be discussed between the physicians and the FMs, sometimes excluding the patients [50]. A physician-FMs coalition was linked to the FMs' roles or attitudes. FMs were involved in a dyadic decision-making with the physicians when they had an active attitude and when they represented an intermediary between the patients and the physicians. Secondly, FMs could be included in a triadic decision-making, in which physicians were the third party of the patient-FM coalition [50]. Approximatively one third of the patients preferred this pattern [32,34,54]. In the case of couples, partners encouraged the patients to get more involved in the treatment discussions. This was defined as a spousal coalition [50]. 


\section{Discussion}

The current review presented the FMs' roles, attitudes, factors of involvement and needs in chronic disease treatment decision-making. Our results are consistent with previous literature reviews $[9,10,18]$, but allow a broader understanding of family involvement in chronic illness across the entire process of treatment decision-making. Indeed, we highlighted the similarities but also the differences in family involvement depending on different factors (e.g., illness, culture).

Among the 5 major themes identified in the present systematic review, two have been widely described: the FMs' roles and the factors influencing family involvement in treatment decisionmaking. For example, the FMs' role of social support is well described. Such support is essential for patients during treatment decision-making and represent an indirect influence. In fact, several studies show that social support (i.e., ability to provide assistance to others) is important in daily life (e.g., stress management) $[61,62]$, as well as when someone faces a severe illness $[63,64]$. The role of social support is undoubtedly the most described in the literature whereas less is known about the roles of intermediaries and collaborators. However, they are more and more studied. Indeed, most of the time FMs, patients and physicians reported seeing family involvement positively (e.g., patients feel less anxious).

The remaining 3 themes (FMs' influence, needs and patterns of decision-making) are rarely described in the literature. Family influence in treatment decision-making can be defined as either direct/indirect and positive/negative. Such influence has not been clearly defined yet, although Rini et al. [45] proposed a questionnaire assessing family influence on the decision to do a colectomy. Several researchers refer to family influence $[36,50,65]$, sometimes with another terminology [9]. Overall, both patients and physicians express positive attitudes toward family involvement in treatment decision-making $[9,38]$ and FMs want to be involved $[9,16,32,35,55,58]$. Secondly, being involved in treatment decision-making generates several needs for FMs (e.g., information). Thus, the FMs' involvement can impact them negatively. They can feel burdened or isolated [33,55]. Although, two articles described a negative impact of the involvement in decision-making on FMs $[33,55]$ no studies 
aimed to assess this effect. Yet, the studies in our systematic review found such impact (e.g., family tensions) $[38,56]$. In other contexts, such as disease management, studies indicate that FMs are more depressed than patients [66-68]. Thirdly, the included studies discussed briefly decision-making patterns. They are not clearly defined. Studies investigating these patterns are needed to understand family involvement better. To date, only one decision-making pattern is clearly conceptualized: "shared decision-making" [5]. By comparison, triadic treatment decision-making has only been recently defined by Laidsaar-Powell et al. [65] with the TRIO Framework, which is specific to cancer treatment decision-making. Such definition is needed for triadic decision-making in the chronic illness context in general.

The themes we described are found in most treatment decision-making pertaining to a chronic illness. However, some specificities exist according to the treatment choice, the disease and the type of FMs involved. First, FMs are more involved when surgery is an option [25,27,40-42]. Secondly, in chronic kidney disease FMs seem to have a more indirect influence $[12,29,57,60]$, whereas in breast cancer, the most reported type of influence is direct influence $[40,53,56]$. Finally, partners seem to be the most involved in treatment decision-making [37,38,51]. Further research needs to investigate why such differences exists to formulate specific recommendations for health professionals.

\section{Limitations}

First, the present results should be read with caution considering the characteristics of the included studies. Most were cross-sectional $(n=35)$, qualitative $(n=26)$, questioned only the patients $(n=21)$ and focused on cancer patients $(n=19)$. Therefore, the results are not generalizable, do not account for the entirety of the decision-making process and are not exempt of retrospective biases. Decision-making may be more studied in oncology because it is a life-threatening illness with multiple heavy treatment options. Furthermore, numerous studies are of low to moderate quality. They present a lack of precision regarding the population or methodology. Secondly, investigating family involvement in treatment choice is not the main objective of most of the included studies. Interestingly, patients mention naturally FMs when they talk about their decision-making process. Thirdly, due to a wide variation of terms used to refer to FMs (e.g., companion, kin, caregiver), some relevant studies may 
not have been included. Finally, the QATSDD could be improved with better defined criteria. Indeed, some items could be clearer by adding examples. Moreover, other items could be weighted as more indicative of a rigorous methodology than others (e.g., sample size vs. user involvement in design). Similar criticism has already been formulated [69].

\section{Conclusion}

FMs are essential in treatment decision-making. However, several gaps exist in our understanding of family involvement throughout this process. Longitudinal and mixed methodology research is needed. Practice and research implications are presented in Box 3. Finally, the potential difficulties FMs face should be considered. This could initiate reflections on family interventions.

Insert «Box 3 »

Acknowledgment: We thank Professor Beatrice Berna for her editorial assistance in English.

Funding: This research did not receive any specific grant from funding agencies in the public, commercial, or not-for-profit sectors.

Conflicts of interest: none. 


\section{References}

1. C. Charles, A. Gafni, T. Whelan, Decision-making in the physician-patient encounter: revisiting the shared treatment decision-making model, Soc Sci Med. 49 (1999) 651-61.

2. G. Makoul, M.L. Claymant, An integrative model of shared decision making in medical encounters, Patient Educ and Couns. 60 (2006) 301-312.

3. M. Stewart, J. Brown, Patient-centredness in medicine, in: A. Edwards, G. Elwyn (Eds), Evidence based patient choice: Inevitable or impossible, Oxford University Press London, 2001, pp. 97-103.

4. E.A. Joosten, L. DeFuentes-Merillas, G.H. de Weert, T. Sensky, C.P. van der Staak, C.A. de Jong, Sytematic review of the effects of shared decision making on patient satisfaction treatment adherence and health status, Psychother Psychosom. 77 (2008) 219-226.

5. C. Charles, A. Gafni, T. Whelan, Shared decision-making in the medical encounter: what does it mean? (Or, it takes at least two to tango), Soc Sci Med. 44 (1997) 681-692.

6. D. Berry, Communication between patient and health professionals, in: D. Berry, Health communication: Theory and practice, Open University Press, New-York, 2007, pp. 39-51.

7. A. Towle, W. Godolphin, G. Grams, A. Lamarre, Putting informed and shared decisionmaking into practice, Health expectations. 9 (2006) 321-332.

8. D.M. Berwick, What 'patient-centered' should mean: Confessions of an extremist, Health Aff. 28 (2009) 555-565.

9. R.C. Laidsaar-Powell, P.N. Butow, S. Bu, C. Charles, A. Gafni, W.W.T. Lam, et al., Physician-patient-companion communication and decision-making: A systematic review of triadic medical consultations, Patient Educ Couns. 91 (2013) 3-13.

10. K. Schumm, Z. Skea, L. McKee, J. N'Dow, 'They're doing surgery on two people': A meta-ethnography of the influences on couples' treatment decision making for prostate cancer, Health Expect. 13 (2010) 335-349. 
11. N. Mendick, B. Young, C. Holcombe, P. et Salmon, The ethics of responsibility and ownership in decision-making about treatment for breast cancer: Triangulation of consultation with patient and surgeon perspectives, Soc Sci Med. 70 (2010) 1904-1911.

12. A. Visser, G.J. Dijkstra, D. Kuiper, P.E. de Jong, C.F.M. Franssen, R.T. Gansevoort, et al., Accepting or declining dialysis: considerations taken into account by elderly patients with end-stage renal disease, JNephrol. 22 (2009) 794-799.

13. J.L. Wolff, D.L. Roter, Family presence in routine medical visits: A meta-analytical review, Soc Sci Med. 72 (2011) 823-831.

14. C. Schäfer, K. Putnik, B. Dietl, P. Leiberich, T.H. Loew, O. Kölbl, Medical decisionmaking of the patient in the context of the family: results of a survey, Support Care Cancer. 14 (2006) 952-959.

15. C. Kimberlin, D. Brushwood, W. Allen, E. Radson, D. Wilson, Cancer patient and caregiver experiences: communication and pain management issues, J Pain Symptom Manag. 28 (2004) 566-578.

16. D.W. Shin, J. Cho, D.L. Roter, S.Y. Kim, S.K. Sohn, M.S. Yoon, et al., Preferences for and experiences of family involvement in cancer treatment decision-making: Patientcaregiver dyads study, Psychooncology. 22 (2013) 2624-2631.

17. D.W. Shin, J. Cho, D.L. Roter, S.Y. Kim, H.K. Yang, K. Park, et al., Attitudes toward family involvement in cancer treatment decision making: The perspectives of patients, family caregivers, and their oncologists, Psychooncology. (2016, in press).

18. R.L. Morton, A. Tong, K. Howard, P. Snelling, A.C. Webster, The views of patients and carers in treatment decision making for chronic kidney disease: systematic review and thematic synthesis of qualitative studies, BMJ. 340 (2010) c112. 
19. D. Moher, A. Liberati, J. Tetzlaff, D.G. Altman, The PRISMA Group, Preferred Reporting Items for Systematic Reviews and Meta-Analyses: The PRISMA Statement, PLoS Med. 6 (2009) e1000097.

20. Adams PF, Kirzinger WK, Martinez ME. Summary health statistics for the U.S. population: National Health Interview Survey, 2012. National Center for Health Statistics. Vital Health Stat. 2013, 10(259), [access $16^{\text {th }}$ June 2017]. Available from: https://www.cdc.gov/nchs/data/series/sr_10/sr10_259.pdf

21. R.F. Baumeister, M.R. Leary, Writing narrative literature reviews, Rev Gen Psychol. 1 (1997) 311-320.

22. R. Sirriyeh, R. Lawton, P. Gardner, G. Armitage, Reviewing studies with diverse designs: the development and evaluation of a new tool, J Eval Clin Pract. 18 (2012) 746-752.

23. J.S. Blumenthal-Barby, K.M. Kostick, E.D. Delgado, R.J. Volk, H.M. Kaplan, L.A. Wilhelms, et al., Assessment of patients' and caregivers' informational and decisional needs for left ventricular assist device placement: Implications for informed consent and shared decision-making, J Hear Lung Transplant. 34 (2015) 1182-1189.

24. J.A Chong, Y.L. Quah, G.M. Yang, S. Menon, L. Kumar, L.K. Radha Krishna, Patient and family involvement in decision making for management of cancer patients at a centre in Singapore, BMJ Support Palliat Care. 5 (2015) 420-426.

25. L. Del Piccolo, C. Goss, A. Bottacini, V. Rigoni, M.A. Mazzi, G. Deledda, et al., Asking questions during breast cancer consultations: Does being alone or being accompanied make a difference?, Eur J Oncol Nurs. 18 (2014) 299-304.

26. E.P. Dellon, M.D. Shores, K.I. Nelson, J. Wolfe, T.L. Noah, L.C. Hanson, Caregiver perspectives on discussions about the use of intensive treatments in cystic fibrosis, J Pain Symptom Manage. 40 (2010) 821-828. 
27. D.E. Hall, P. Morrison, C. Nikolajski, M. Fine, R. Arnold, S.L. Zickmund, Informed consent for inguinal herniorrhaphy and cholecystectomy: Describing how patients make decisions to have surgery, Am J Surg. 204 (2012) 619-625.

28. J. Harrington, M. Morgan, Understanding kidney transplant patients' treatment choices: The interaction of emotion with medical and social influences on risk preferences, Soc Sci Med. 155 (2016) 43-50.

29. L. Harwood, A.M. Clark, Dialysis modality decision-making for older adults with chronic kidney disease, J Clin Nurs. 23 (2014) 3378-3390.

30. D.H. Hirpara, M.C. Cleghorn, S. Sockalingam, F.A. Quereshy, Understanding the complexities of shared decision-making in cancer: A qualitative study of the perspectives of patients undergoing colorectal surgery, Can J Surg. 59 (2016) 197-204.

31. G. Hubbard, N. Illingworth, N. Rowa-Dewar, L. Forbat, N. Kearney, Treatment decisionmaking in cancer care: The role of the carer, J Clin Nurs. 19 (2010) 2023-2031.

32. M. Ito, N. Tanida, S. Turale, Perceptions of Japanese patients and their family about medical treatment decisions, Nurs Heal Sci. 12 (2010) 314-321.

33. B. Ivarsson, B. Ekmehag, T. Sjöberg, Relative's experiences before and after a heart or lung transplantation, Hear Lung. 43 (2014) 198-203.

34. P. Jordan, S. Quadrelli, M. Heres, L. Belli, N. Ruhl, H. Colt, Examining patients' preferences for participation in clinical decision-making: The experience in a Latin American chronic obstructive pulmonary disease and cancer outpatient population, Intern Med J. 44 (2014) 281-287.

35. J.L. Krieger, A.L. Palmer-Wackerly, J.L. Krok-Schoen, P.M. Dailey, J.C. Wojno, N. Schoenberg, et al., Caregiver Perceptions of Their Influence on Cancer Treatment Decision Making: Intersections of Language, Identity, and Illness, J Lang Soc Psychol. 34 (2015) 640-656. 
36. R. Laidsaar-Powell, P. Butow, S. Bu, C. Charles, A. Gafni, A. Fisher, et al., Family involvement in cancer treatment decision-making: A qualitative study of patient, family, and clinician attitudes and experiences, Patient Educ Couns. 99 (2016) 1146-1155.

37. R. Laidsaar-Powell, P. Butow, S. Bu, R. Dear, A. Fisher, J. Coll, et al., Exploring the communication of oncologists, patients and family members in cancer consultations: development and application of a coding system capturing family-relevant behaviours (KINcode), Psychooncology. 25 (2016) 787-794.

38. R. Laidsaar-Powell, P. Butow, S. Bu, A. Fisher, I. Juraskova, Attitudes and experiences of family involvement in cancer consultations: A qualitative exploration of patient and family member perspectives, Support Care Cancer. 24 (2016) 4131-4140.

39. W.W.T. Lam, M. Kwok, M. Chan, W.K. Hung, M. Ying, A. Or, et al., Does the use of shared decision-making consultation behaviors increase treatment decision-making satisfaction among Chinese women facing decision for breast cancer surgery?, Patient Educ Couns. 94 (2014) 243-249.

40. S.K.C. Lee, M.T. Knobf, Family involvement for breast cancer decision making among Chinese-American women, Psychooncology. 25 (2016) 1493-1499.

41. M.L. Lin, M.C.S. Pang, C.H. Chen, Family as a whole: Elective surgery patients' perception of the meaning of family involvement in decision making, J Clin Nurs. 22 (2013) 271-278.

42. M.L. Lin, C.T. Huang, C.H. Chen, Reasons for family involvement in elective surgical decision-making in Taiwan: A qualitative study, J Clin Nurs. (2016, in press)

43. D. Lowden, V. Lee, J.A. Ritchie, Redefining self: Patients' decision making about treatment for multiple sclerosis, J Neurosci Nurs. 46 (2014) E14-24.

44. K. Pardon, R. Deschepper, R. Vander Stichele, J.L. Bernheim, F. Mortier, D. Schallier, et al., Preferred and actual involvement of advanced lung cancer patients and their families 
in end-of-life decision making: A multicenter study in 13 hospitals in Flanders, Belgium, $\mathbf{J}$ Pain Symptom Manage. 43 (2012) 515-526.

45. C. Rini, L. Jandorf, R.E. Goldsmith, S.L. Manne, N. Harpaz, S.H. Itzkowitz. Interpersonal influences on patients' surgical decision making: The role of close others, J Behav Med. 34 (2011) 396-407.

46. M.L. Salter, M.A. McAdams-Demarco, A. Law, R.J. Kamil, L.A. Meoni, B.G. Jaar, et al., Age and sex disparities in discussions about kidney transplantation in adults undergoing dialysis, J Am Geriatr Soc. 62 (2014) 843-849.

47. J. Shaw, X. Zou, P. Butow, Treatment decision making experiences of migrant cancer patients and their families in Australia, Patient Educ Couns. 98 (2015) 742-747.

48. R.C. Shelton, G.C. Hillyer, D.L. Hershman, N. Leoce, D.H. Bovbjerg, J.S. Mandelblatt, et al., Interpersonal influences and attitudes about adjuvant therapy treatment decisions among non-metastatic breast cancer patients: An examination of differences by age and race/ethnicity in the BQUAL study, Breast Cancer Res Treat. 137 (2013) 817-828.

49. E. Uldry, M. Schäfer, A. Saadi, V. Rousson, N. Demartines, Patients' preferences on information and involvement in decision making for gastrointestinal surgery, World $\mathbf{J}$ Surg. 37 (2013) 2162-2171.

50. U. Boehmer, J.A. Clark, Married couples' perspectives on prostate cancer diagnosis and treatment decision-making, Psychooncology. 10 (2001) 147-155.

51. M.L. Clayman, D. Roter, L.S. Wissow, K. Bandeen-Roche, Autonomy-related behaviors of patient companions and their effect on decision-making activity in geriatric primary care visits, Soc Sci Med. 60 (2005) 1583-1591.

52. L.F. Degner, J.A. Sloan, Decision making during serious illness: What role do patients really want to play?, J Clin Epidemiol. 45 (1992) 941-950. 
53. L. Elit, C. Charles, I. Gold, A. Gafni, S. Farrell, S. Tedford, et al., Women's perceptions about treatment decision making for ovarian cancer, Gynecol Oncol. 88 (2003) 89-95.

54. D.K. Heyland, C. Frank, D. Groll, D. Pichora, P. Dodek, G. Rocker, et al., Understanding cardiopulmonary resuscitation decision making: Perspectives of seriously III hospitalized patients and family members, Chest. 130 (2006) 419-428.

55. S. McSkimming, M. Hodges, A. Super, M. Driever, M. Schoessler, S.G. Franey, et al., The experience of life-threatening illness: Patients' and their loved ones' perspectives, J Palliat Med. J Palliat Med. 2 (1999) 173-184.

56. J. Öhlén, L.G. Balneaves, J.L. Bottorff, A.S.A. Brazier, The influence of significant others in complementary and alternative medicine decisions by cancer patients, Soc Sci Med. 63 (2006) 1625-1636.

57. D.B. Wuerth, S.H. Finkelstein, O. Schwetz, H. Carey, A.S. Kliger, F.O. Finkelstein, Patients' descriptions of specific factors leading to modality selection of chronic peritoneal dialysis or hemodialysis, Perit Dial Int. 22 (2002) 184-190.

58. P. Sinfield, R. Baker, S. Agarwal, C. Tarrant, Patient-centred care: What are the experiences of prostate cancer patients and their partners?, Patient Educ Couns. 73 (2008) 91-96.

59. P. Rotman-Pikielny, B. Rabin, S. Amoyal, Y. Mushkat, R. Zissin, Y. Levy, Participation of family members in ward rounds: Attitude of medical staff, patients and relatives, Patient Educ Couns. 65 (2007) 166-170.

60. A. Tong, P. Sainsbury, S. Chadban, R.G. Walker, D.C. Harris, S.M. Carter, et al., Patients' experiences and perspectives of living with CKD, Am J Kidney Dis. 53 (2009) $689-700$.

61. S. Cohen, T.A. Wills, Stress, social support, and the buffering hypothesis, Psychol Bull. 98 (1985) 310-357. 
62. I.G. Sarason, B.R. Sarason, G.R. Pierce, Stress and social support, in: S.E. Hobfoll, M.W. de Vries (Eds), Extreme stress and communities: Impact and intervention, Kluwer Academic Publishers, 1995, pp. 179-197.

63. C.A. Berg, R. Upchurch, A developmental-contextual model of couples coping with chronic illness across the adult life span, Psychol Bull. 133 (2007) 920-954.

64. D.O. Frohlich, The social support model for people with chronic health conditions: A proposal for future research, Soc Theory and Health. 12 (2014) 218-234.

65. R. Laidsaar-Powell, P. Butow, C. Charles, A. Gafni, V. Entwistle, R. Epstein, et al., The TRIO Framework: Conceptual insights into family caregiver involvement and influence throughout cancer treatment decision-making, Patient Educ and Couns. Forthcoming.

66. C.Y. Chiao, H.S. Wy, C.Y. Hsiao, Caregiver burden for informal caregivers of patients with dementia: A systematic review, Int Nurs Rev. 62 (2015) 340-350.

67. E.K. Choi, S.J. Yoon, J.H. Kim, H.J. Park, J.Y. Kim, E.S. Yu, Depression and distress in caregivers of children with brain tumors undergoing treatment: Psychosocial factors as moderators, Psychooncology. 25 (2016) 544-550.

68. L.L. Northouse, M.C. Katapodi, A.M. Schafenacker, D. Weiss, The impact of caregiving on the psychological well-being of family caregivers and cancer patients, Semin Oncol Nurs. 28 (2012) 236-245.

69. L. Fenton, H. Lauckner, R. Gilbert, The QATSDD critical appraisal tool: comments and critics. J Eval Clin Pract. 21 (2015) 1125-1128.

70. S. Mitnick, C. Leffler, V. Hood, Family caregivers, patients and physicians: ethical guidance to optimize relationships. J Gen Intern Med. 25 (2010) 255-260. 


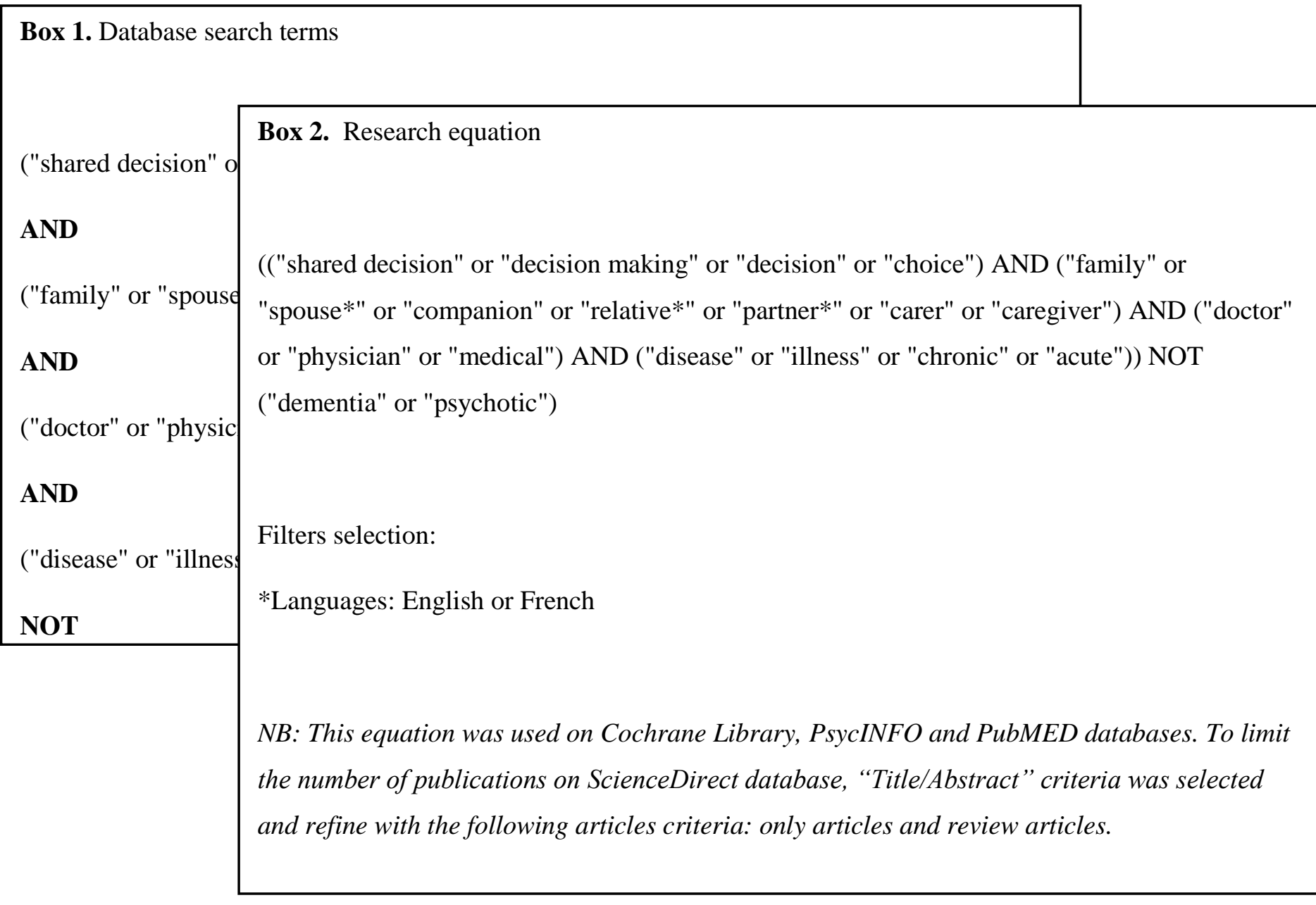


Figure 1. Flow diagram of study selection
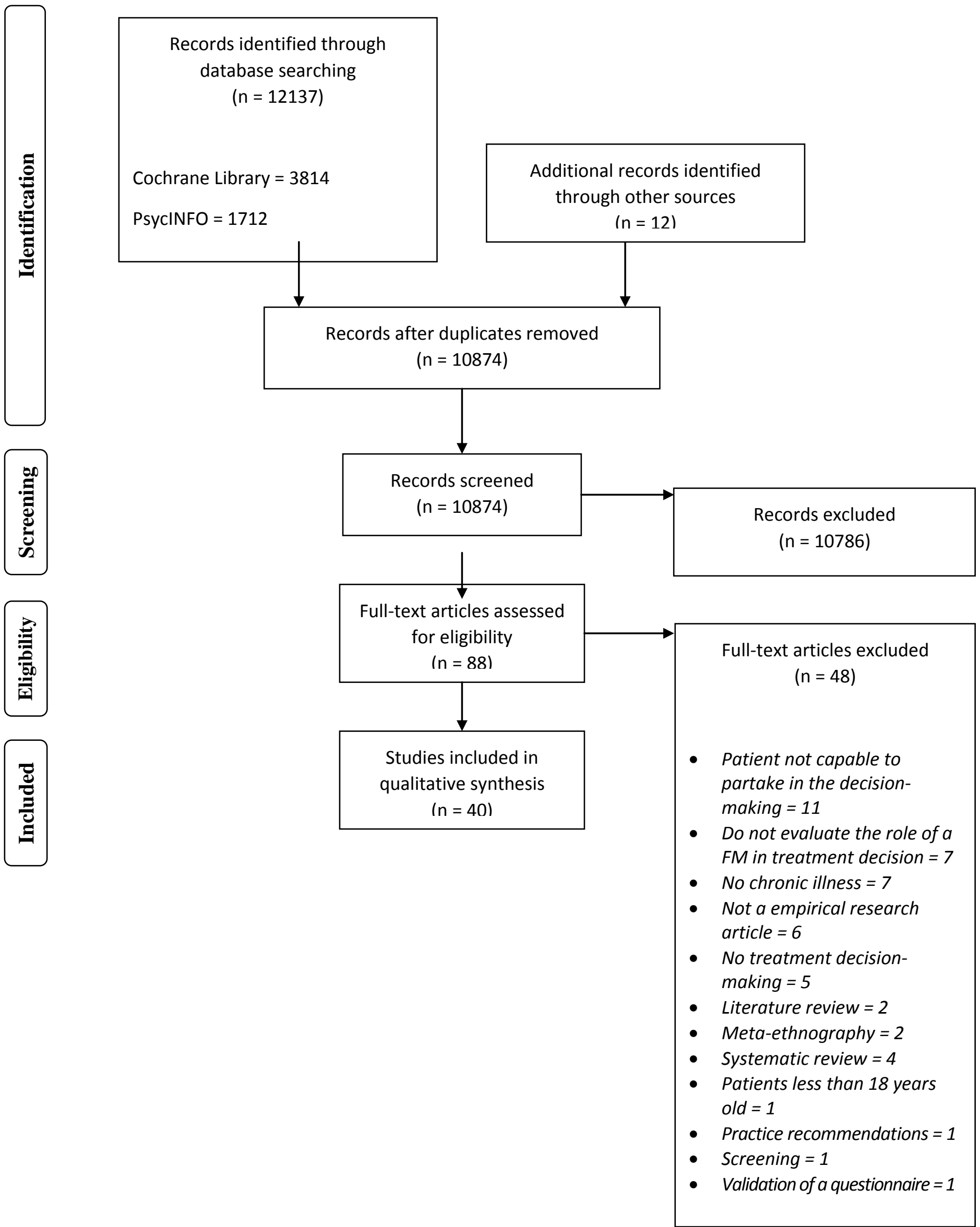
Box 3. Practice and research implications

Practice implications*

- Physicians should include FMs in treatment decision-making when the patients (and their FMs) wish to. During the consultation, when FMs adopt helpful behaviors (e.g., provide information to the physician, support the patient), they could reinforce the patient-physician relationship.

- FMs can be an asset for the patients and the medical teams, before, during and after the consultations. Indeed, patients talk to their family about their disease and the treatment decision they have to make.

- Talk with the family. FMs can adopt helpful behaviors but sometimes they need to be guided (i.e., patients or physicians should explain to FMs what behaviors could be helpful for the patient).

- Listen the patient and do not systematically exclude FMs from treatment decisionmaking. Some patients want their FMs to be included but sometimes, a private patientphysician discussion can allow the patient to talk about "delicate" subjects (e.g., sexuality).

\section{$\underline{\text { Research implications }}$}

- Mixed methodologies can be considered as a gold standard to evaluate and understand treatment decision-making. Qualitative designs allow to comprehend the complexity of this process. Quantitative designs allow to assess parts of the process with a large number of participants.

- Longitudinal studies are needed to understand treatment decision-making better. Currently, studies are mostly retrospective and cross-sectional. Since decision-making is a process, longitudinal methodologies could allow us to better comprehend treatment choice from the first symptoms of the illness to the consequences of this decision to evaluate its long-term impact.

- Reliable quantitative tools need to be developed to assess family involvement in treatment decision-making. To our knowledge, only Rini et al. [45] proposed a questionnaire to evaluate positive/negative and direct/indirect influence, but a validation is needed. Furthermore, such questionnaire could help researchers to evaluate how prevalent these influences are and to assess the variation of the FMs' needs or influences according to several factors (e.g., stage of the illness, relationship with the patient).

- Studies comparing family involvement according to the FMs' status (e.g., partners, parents or aunt/uncle) and the patients' diseases would help to better comprehend their role(s) in decision-making. Few distinctions are made in the included studies. Some of them directly compare which FM is more involved (generally the spouse). To date, studies only investigate family involvement in one population (principally cancer) and do not make comparisons between chronic diseases. 
Appendix 1. Quality assessment of the studies included in the systematic review

\begin{tabular}{|c|c|c|c|c|c|c|}
\hline Item $($ Score 0 - 3) & $\begin{array}{c}\quad[12] \\
\text { Visser et } \\
\text { al., } 2009\end{array}$ & $\begin{array}{c}{[16]} \\
\text { Shin et al., } \\
2013\end{array}$ & $\begin{array}{c}{[23]} \\
\text { Blumenthal- } \\
\text { Bardy et al. } \\
2015\end{array}$ & $\begin{array}{l}\quad[24] \\
\text { Chong et } \\
\text { al., } 2012\end{array}$ & $\begin{array}{c}\text { [25] } \\
\text { Del } \\
\text { Piccolo et } \\
\text { al., } 2014\end{array}$ & $\begin{array}{l}\text { [26] } \\
\text { Dellon et } \\
\text { al., } 2012\end{array}$ \\
\hline 1. Explicit theoretical framework & 1 & 2 & 1 & 2 & 3 & 1 \\
\hline 2.Statement of aims/objectives in main body of report & 3 & 3 & 3 & 3 & 3 & 3 \\
\hline 3.Clear description of research setting & 3 & 3 & 3 & 2 & 3 & 3 \\
\hline 4.Evidence of sample size considered in terms of analysis & 0 & 0 & 0 & 2 & 0 & 1 \\
\hline 5.Representative sample of target group of a reasonable size & 2 & 3 & 1 & 2 & 2 & 2 \\
\hline 6.Description of procedure for data collection & 2 & 2 & 2 & 3 & 3 & 2 \\
\hline 7.Rationale for choice of data collection tool(s) & 0 & 1 & 3 & 0 & 0 & 1 \\
\hline 8.Detailed recruitment data & 0 & 1 & 0 & 3 & 3 & 3 \\
\hline $\begin{array}{l}\text { 9.Statistical assessment of reliability and validity of measurement tool(s) } \\
\text { (Quant. only) }\end{array}$ & I & 2 & I & 0 & 0 & I \\
\hline $\begin{array}{l}\text { 10. Fit between stated research question and method of data collection } \\
\text { (Quant. only) }\end{array}$ & I & 2 & I & 1 & 3 & I \\
\hline $\begin{array}{l}\text { 11. Fit between stated research question and format and content of data } \\
\text { collection tool. (Qual. only) }\end{array}$ & 2 & l & 3 & l & 3 & 2 \\
\hline 12.Fit between research question and method of analysis & 1 & 2 & 1 & 1 & 2 & 1 \\
\hline 13.Good justification for analytical method selected & 0 & 0 & 0 & 1 & 2 & 0 \\
\hline 14.Assessment of reliability of analytic process (Qual. only) & 1 & I & 1 & I & 3 & 0 \\
\hline 15.Evidence of user involvement in design & 0 & 1 & 0 & 0 & 0 & 0 \\
\hline 16.Strengths and limitations critically discussed & 2 & 3 & 1 & 2 & 2 & 2 \\
\hline Total score (sum) & 17 & 25 & 19 & 22 & 32 & 21 \\
\hline Percentage score & $38 \%$ & $56 \%$ & $42 \%$ & $49 \%$ & $63 \%$ & $47 \%$ \\
\hline
\end{tabular}




\begin{tabular}{|c|c|c|c|c|c|c|}
\hline Item (Score 0 - 3) & $\begin{array}{c}{[27]} \\
\text { Hall et al., } \\
2012\end{array}$ & $\begin{array}{l}{[28]} \\
\text { Harrington } \\
\text { \& Morgan, } \\
2016\end{array}$ & $\begin{array}{l}\quad[29] \\
\text { Harwood } \\
\text { et al., } 2014\end{array}$ & $\begin{array}{c}{[30]} \\
\text { Hirpara et } \\
\text { al., } 2016\end{array}$ & $\begin{array}{c}{[31]} \\
\text { Hubbard et } \\
\text { al., } 2010\end{array}$ & $\begin{array}{c}{[32]} \\
\text { Ito et al. } \\
2010\end{array}$ \\
\hline 1. Explicit theoretical framework & 2 & 2 & 3 & 1 & 3 & 3 \\
\hline 2.Statement of aims/objectives in main body of report & 3 & 3 & 3 & 3 & 3 & 3 \\
\hline 3.Clear description of research setting & 3 & 2 & 2 & 3 & 1 & 1 \\
\hline 4.Evidence of sample size considered in terms of analysis & 0 & 3 & 3 & 3 & 1 & 0 \\
\hline 5.Representative sample of target group of a reasonable size & 2 & 2 & 2 & 2 & 2 & 2 \\
\hline 6.Description of procedure for data collection & 3 & 2 & 0 & 1 & 2 & 2 \\
\hline 7.Rationale for choice of data collection tool(s) & 1 & 0 & 0 & 1 & 2 & 2 \\
\hline 8.Detailed recruitment data & 3 & 0 & 0 & 0 & 0 & 1 \\
\hline $\begin{array}{l}\text { 9. Statistical assessment of reliability and validity of measurement tool(s) } \\
\text { (Quant. only) }\end{array}$ & I & I & I & I & I & 1 \\
\hline $\begin{array}{l}\text { 10. Fit between stated research question and method of data collection } \\
\text { (Quant. only) }\end{array}$ & l & l & l & / & l & 1 \\
\hline $\begin{array}{l}\text { 11. Fit between stated research question and format and content of data } \\
\text { collection tool. (Qual. only) }\end{array}$ & 3 & 2 & 1 & 2 & 2 & l \\
\hline 12.Fit between research question and method of analysis & 1 & & 2 & 1 & 3 & 1 \\
\hline 13.Good justification for analytical method selected & 0 & 0 & 0 & 0 & 3 & 1 \\
\hline 14.Assessment of reliability of analytic process (Qual. only) & 3 & 0 & 1 & 1 & 0 & I \\
\hline 15.Evidence of user involvement in design & 2 & 0 & 0 & 0 & 0 & 1 \\
\hline 16.Strengths and limitations critically discussed & 2 & 1 & 1 & 2 & 0 & 0 \\
\hline Total score (sum) & 28 & 18 & 18 & 20 & 22 & 19 \\
\hline Percentage score & $61 \%$ & $40 \%$ & $40 \%$ & $44 \%$ & $49 \%$ & $42 \%$ \\
\hline
\end{tabular}




\begin{tabular}{|c|c|c|c|c|c|c|}
\hline Item (Score 0 - 3) & $\begin{array}{c}{[33]} \\
\text { Ivarsson et } \\
\text { al., } 2014\end{array}$ & $\begin{array}{c}{[34]} \\
\text { Jordan et } \\
\text { al., } 2014\end{array}$ & $\begin{array}{c}{[35]} \\
\text { Krieger et } \\
\text { al., } 2015\end{array}$ & $\begin{array}{l}\quad[36] \\
\text { Laidsaar- } \\
\text { Powell et } \\
\text { al., } 2016\end{array}$ & $\begin{array}{l}\quad[37] \\
\text { Laidsaar- } \\
\text { Powell et } \\
\text { al., } 2016\end{array}$ & $\begin{array}{c}\quad[38] \\
\text { Laidsaar- } \\
\text { Powel et } \\
\text { al., } 2016\end{array}$ \\
\hline 1. Explicit theoretical framework & 3 & 2 & 3 & 2 & 3 & 2 \\
\hline 2. Statement of aims/objectives in main body of report & 3 & 3 & 3 & 3 & 3 & 3 \\
\hline 3.Clear description of research setting & 2 & 3 & 3 & 3 & 0 & 3 \\
\hline 4.Evidence of sample size considered in terms of analysis & 0 & 0 & 0 & 3 & 0 & 2 \\
\hline 5.Representative sample of target group of a reasonable size & 2 & 2 & 2 & 3 & 3 & 3 \\
\hline 6.Description of procedure for data collection & 2 & 3 & 3 & 2 & 1 & 2 \\
\hline 7.Rationale for choice of data collection tool(s) & 0 & 0 & 0 & 3 & 3 & 2 \\
\hline 8.Detailed recruitment data & 0 & 0 & 3 & 3 & 0 & 0 \\
\hline $\begin{array}{l}\text { 9. Statistical assessment of reliability and validity of measurement tool(s) } \\
\text { (Quant. only) }\end{array}$ & I & 0 & I & I & 2 & I \\
\hline $\begin{array}{l}\text { 10. Fit between stated research question and method of data collection } \\
\text { (Quant. only) }\end{array}$ & l & 2 & l & / & 3 & l \\
\hline $\begin{array}{l}\text { 11. Fit between stated research question and format and content of data } \\
\text { collection tool. (Qual. only) }\end{array}$ & 2 & I & 2 & 3 & l & 3 \\
\hline 12.Fit between research question and method of analysis & 2 & 2 & 2 & 3 & 3 & 3 \\
\hline 13.Good justification for analytical method selected & 0 & 0 & 0 & 0 & 0 & 1 \\
\hline 14.Assessment of reliability of analytic process (Qual. only) & 1 & I & 3 & 1 & l & 1 \\
\hline 15.Evidence of user involvement in design & 0 & 1 & 0 & 0 & 0 & 0 \\
\hline 16.Strengths and limitations critically discussed & 1 & 1 & 0 & 3 & 3 & 1 \\
\hline Total score (sum) & 18 & 19 & 24 & 32 & 24 & 26 \\
\hline Percentage score & $40 \%$ & $42 \%$ & $53 \%$ & $71 \%$ & $53 \%$ & $58 \%$ \\
\hline
\end{tabular}




\begin{tabular}{|c|c|c|c|c|c|c|}
\hline Item $($ Score 0 - 3) & $\begin{array}{c}{[39]} \\
\text { Lam et al., } \\
2013\end{array}$ & $\begin{array}{l}{[40]} \\
\text { Lee et al., } \\
2016\end{array}$ & $\begin{array}{c}{[41]} \\
\text { Lin et al., } \\
2012\end{array}$ & $\begin{array}{c}{[42]} \\
\text { Lin et al., } \\
2016\end{array}$ & $\begin{array}{c}\text { [43] } \\
\text { Lowden et } \\
\text { al., } 2014\end{array}$ & $\begin{array}{l}\quad[44] \\
\text { Pardon et } \\
\text { al., } 2012\end{array}$ \\
\hline 1. Explicit theoretical framework & 2 & 2 & 3 & 3 & 3 & 3 \\
\hline 2.Statement of aims/objectives in main body of report & 3 & 3 & 3 & 3 & 3 & 3 \\
\hline 3.Clear description of research setting & 3 & 3 & 3 & 3 & 3 & 3 \\
\hline 4.Evidence of sample size considered in terms of analysis & 0 & 0 & 3 & 3 & 3 & 1 \\
\hline 5.Representative sample of target group of a reasonable size & 3 & 2 & 2 & 2 & 2 & 3 \\
\hline 6.Description of procedure for data collection & 2 & 1 & 3 & 3 & 2 & 2 \\
\hline 7.Rationale for choice of data collection tool(s) & 1 & 1 & 0 & 0 & 2 & 0 \\
\hline 8.Detailed recruitment data & 3 & 0 & 0 & 2 & 0 & 2 \\
\hline $\begin{array}{l}\text { 9. Statistical assessment of reliability and validity of measurement tool(s) } \\
\text { (Quant. only) }\end{array}$ & 1 & l & I & I & l & 0 \\
\hline $\begin{array}{l}\text { 10. Fit between stated research question and method of data collection } \\
\text { (Quant. only) }\end{array}$ & 2 & l & l & l & I & 2 \\
\hline $\begin{array}{l}\text { 11. Fit between stated research question and format and content of data } \\
\text { collection tool. (Qual. only) }\end{array}$ & 3 & 2 & 2 & 2 & 3 & I \\
\hline 12.Fit between research question and method of analysis & 3 & 2 & 2 & 3 & 3 & 1 \\
\hline 13.Good justification for analytical method selected & 2 & 0 & 2 & 0 & 3 & 0 \\
\hline 14.Assessment of reliability of analytic process (Qual. only) & 3 & 1 & 1 & 1 & 1 & I \\
\hline 15.Evidence of user involvement in design & 0 & 0 & 0 & 0 & 0 & 0 \\
\hline 16.Strengths and limitations critically discussed & 0 & 1 & 2 & 0 & 1 & 2 \\
\hline Total score (sum) & 31 & 18 & 26 & 25 & 29 & 22 \\
\hline Percentage score & $61 \%$ & $40 \%$ & $58 \%$ & $56 \%$ & $64 \%$ & $49 \%$ \\
\hline
\end{tabular}




\begin{tabular}{|c|c|c|c|c|c|c|}
\hline Item $($ Score 0 - 3) & $\begin{array}{l}\quad[45] \\
\text { Rini et al., } \\
2011\end{array}$ & $\begin{array}{c}{[46]} \\
\text { Salter et } \\
\text { al., } 2014\end{array}$ & $\begin{array}{c}{[47]} \\
\text { Shaw et } \\
\text { al., } 2015\end{array}$ & $\begin{array}{c}\quad[48] \\
\text { Shelton et } \\
\text { al., } 2013\end{array}$ & $\begin{array}{l}\text { [49] } \\
\text { Uldry et } \\
\text { al., } 2013\end{array}$ & $\begin{array}{c}{[50]} \\
\text { Boehmer } \\
\& \text { Clarck } \\
2001\end{array}$ \\
\hline 1. Explicit theoretical framework & 3 & 3 & 3 & 3 & 1 & 3 \\
\hline 2.Statement of aims/objectives in main body of report & 3 & 3 & 3 & 1 & 3 & 3 \\
\hline 3.Clear description of research setting & 3 & 3 & 2 & 3 & 2 & 2 \\
\hline 4.Evidence of sample size considered in terms of analysis & 0 & 0 & 3 & 0 & 3 & 0 \\
\hline 5.Representative sample of target group of a reasonable size & 3 & 3 & 3 & 3 & 2 & 0 \\
\hline 6.Description of procedure for data collection & 2 & 0 & 2 & 2 & 3 & 1 \\
\hline 7.Rationale for choice of data collection tool(s) & 1 & 0 & 0 & 0 & 2 & 0 \\
\hline 8.Detailed recruitment data & 3 & 0 & 0 & 3 & 3 & 0 \\
\hline $\begin{array}{l}\text { 9.Statistical assessment of reliability and validity of measurement tool(s) } \\
\text { (Quant. only) }\end{array}$ & 1 & 0 & / & 2 & 0 & / \\
\hline $\begin{array}{l}\text { 10. Fit between stated research question and method of data collection } \\
\text { (Quant. only) }\end{array}$ & 3 & 2 & I & 2 & 2 & / \\
\hline $\begin{array}{l}\text { 11. Fit between stated research question and format and content of data } \\
\text { collection tool. (Qual. only) }\end{array}$ & / & / & 2 & / & / & 2 \\
\hline 12.Fit between research question and method of analysis & 2 & 3 & 2 & 2 & 2 & 2 \\
\hline 13.Good justification for analytical method selected & 0 & 1 & 0 & 1 & 1 & 0 \\
\hline 14.Assessment of reliability of analytic process (Qual. only) & I & 1 & 1 & I & I & 1 \\
\hline 15.Evidence of user involvement in design & 1 & 0 & 0 & 0 & 0 & 0 \\
\hline 16.Strengths and limitations critically discussed & 3 & 1 & 1 & 2 & 2 & 1 \\
\hline Total score (sum) & 28 & 19 & 22 & 24 & 26 & 15 \\
\hline Percentage score & $62 \%$ & $42 \%$ & $49 \%$ & $53 \%$ & $58 \%$ & $33 \%$ \\
\hline
\end{tabular}




\begin{tabular}{|c|c|c|c|c|c|c|}
\hline Item $($ Score 0 - 3) & $\begin{array}{c}\text { [51] } \\
\text { Clayman } \\
\text { et al., 2005 }\end{array}$ & $\begin{array}{c}{[52]} \\
\text { Degner et } \\
\text { al., } 1992\end{array}$ & $\begin{array}{c}\text { [53] } \\
\text { Elit et al., } \\
2012\end{array}$ & $\begin{array}{c}{[54]} \\
\text { Heyland et } \\
\text { al., } 2006\end{array}$ & $\begin{array}{c}\quad[55] \\
\text { McSkimming } \\
\text { et al., } 1999\end{array}$ & $\begin{array}{c}{[56]} \\
\text { Ohlen et } \\
\text { al., } 2006\end{array}$ \\
\hline 1. Explicit theoretical framework & 3 & 1 & 1 & 2 & 1 & 3 \\
\hline 2.Statement of aims/objectives in main body of report & 2 & 3 & 3 & 3 & 2 & 3 \\
\hline 3.Clear description of research setting & 3 & 3 & 3 & 3 & 2 & 3 \\
\hline 4.Evidence of sample size considered in terms of analysis & 0 & 0 & 0 & 2 & 0 & 0 \\
\hline 5.Representative sample of target group of a reasonable size & 2 & 3 & 2 & 3 & 2 & 3 \\
\hline 6.Description of procedure for data collection & 2 & 1 & 2 & 2 & 1 & 3 \\
\hline 7.Rationale for choice of data collection tool(s) & 0 & 2 & 3 & 2 & 0 & 0 \\
\hline 8.Detailed recruitment data & 2 & 0 & 3 & 3 & 0 & \\
\hline $\begin{array}{l}\text { 9.Statistical assessment of reliability and validity of measurement tool(s) } \\
\text { (Quant. only) }\end{array}$ & / & 2 & I & 0 & I & / \\
\hline $\begin{array}{l}\text { 10. Fit between stated research question and method of data collection } \\
\text { (Quant. only) }\end{array}$ & I & 3 & l & 1 & / & I \\
\hline $\begin{array}{l}\text { 11. Fit between stated research question and format and content of data } \\
\text { collection tool. (Qual. only) }\end{array}$ & 2 & / & 3 & l & 3 & 2 \\
\hline 12.Fit between research question and method of analysis & 3 & 3 & 3 & 2 & 1 & 3 \\
\hline 13.Good justification for analytical method selected & 1 & 0 & 2 & 2 & 0 & 1 \\
\hline 14.Assessment of reliability of analytic process (Qual. only) & 0 & I & 1 & I & 1 & 1 \\
\hline 15.Evidence of user involvement in design & 0 & 1 & 2 & 3 & 0 & 0 \\
\hline 16.Strengths and limitations critically discussed & 2 & 1 & 0 & 2 & 2 & 2 \\
\hline Total score (sum) & 22 & 23 & 28 & 30 & 15 & 24 \\
\hline Percentage score & $49 \%$ & $51 \%$ & $62 \%$ & $67 \%$ & $33 \%$ & $53 \%$ \\
\hline
\end{tabular}




\begin{tabular}{|c|c|c|c|c|c|}
\hline Item $($ Score 0 - 3) & $\begin{array}{l}\quad[57] \\
\text { Wuerth et } \\
\text { al., } 2002\end{array}$ & $\begin{array}{c}{[58]} \\
\text { Sinfield et } \\
\text { al., } 2008\end{array}$ & $\begin{array}{l}\quad[59] \\
\text { Rotman- } \\
\text { Pikielny et } \\
\text { al., } 2006\end{array}$ & $\begin{array}{c}{[60]} \\
\text { Tong et } \\
\text { al., } 2009\end{array}$ & $\begin{array}{c}\text { Total } \\
\text { score } \\
\text { (mean) }\end{array}$ \\
\hline 1. Explicit theoretical framework & 1 & 1 & 2 & 1 & 2.18 \\
\hline 2.Statement of aims/objectives in main body of report & 2 & 3 & 3 & 3 & 2.88 \\
\hline 3.Clear description of research setting & 3 & 2 & 2 & 2 & 2.55 \\
\hline 4.Evidence of sample size considered in terms of analysis & 0 & 0 & 0 & 0 & 0.90 \\
\hline 5.Representative sample of target group of a reasonable size & 2 & 2 & 1 & 2 & 2.23 \\
\hline 6.Description of procedure for data collection & 2 & 2 & 1 & 2 & 1.95 \\
\hline 7.Rationale for choice of data collection tool(s) & 0 & 1 & 1 & 0 & 0.88 \\
\hline 8.Detailed recruitment data & 3 & 0 & 0 & 1 & 1.23 \\
\hline $\begin{array}{l}\text { 9. Statistical assessment of reliability and validity of measurement } \\
\text { tool(s) (Quant. only) }\end{array}$ & / & / & 0 & / & 0.73 \\
\hline $\begin{array}{l}\text { 10. Fit between stated research question and method of data collection } \\
\text { (Quant. only) }\end{array}$ & l & l & 1 & / & 2.00 \\
\hline $\begin{array}{l}\text { 11. Fit between stated research question and format and content of } \\
\text { data collection tool. (Qual. only) }\end{array}$ & 2 & 3 & l & 3 & 2.37 \\
\hline 12.Fit between research question and method of analysis & 1 & 3 & 2 & 1 & 2.03 \\
\hline 13.Good justification for analytical method selected & 1 & 0 & 0 & 0 & 0.63 \\
\hline 14.Assessment of reliability of analytic process (Qual. only) & 1 & 1 & / & 1 & 1.15 \\
\hline 15.Evidence of user involvement in design & 0 & 0 & 0 & 0 & 0.30 \\
\hline 16.Strengths and limitations critically discussed & 1 & 1 & 1 & 1 & 1.40 \\
\hline Total score (sum) & 19 & 19 & 14 & 17 & 22.50 \\
\hline Percentage score & $42 \%$ & $42 \%$ & $31 \%$ & $38 \%$ & $50 \%$ \\
\hline
\end{tabular}

Note: Quality criteria $-0=$ not met at all; $1=$ very slightly met; $2=$ moderately met; $3=$ Completely met.

Appendix 2. Mean quality of included studies by themes and subthemes 


\begin{tabular}{|c|c|c|c|c|}
\hline \multirow[b]{2}{*}{ Item $($ Score 0 - 3) } & \multicolumn{4}{|c|}{ Theme 1: Role of the family } \\
\hline & $\begin{array}{c}\text { 1/ FMs as } \\
\text { a source of } \\
\text { social } \\
\text { support } \\
(\mathrm{n}=15)\end{array}$ & $\begin{array}{c}\text { 2/ FMs as } \\
\text { communication } \\
\text { channels } \\
(n=13)\end{array}$ & $\begin{array}{c}\text { 3/ FMs as } \\
\text { collaborators } \\
(\mathrm{n}=13)\end{array}$ & $\begin{array}{c}\text { 4/ FMs as } \\
\text { messengers } \\
(n=1)\end{array}$ \\
\hline 1. Explicit theoretical framework & 2.40 & 2.31 & 2.62 & 2 \\
\hline 2.Statement of aims/objectives in main body of report & 3 & 2.92 & 2.92 & 3 \\
\hline 3.Clear description of research setting & 2.60 & 2.54 & 2.54 & 3 \\
\hline 4.Evidence of sample size considered in terms of analysis & 1.13 & 1.31 & 1.38 & 2 \\
\hline 5.Representative sample of target group of a reasonable size & 2.33 & 2.08 & 2.31 & 3 \\
\hline 6.Description of procedure for data collection & 2 & 2.08 & 1.92 & 2 \\
\hline 7.Rationale for choice of data collection tool(s) & 0.93 & 0.85 & 1.08 & 2 \\
\hline 8.Detailed recruitment data & 0.86 & 1.17 & 0.92 & 0 \\
\hline 9.Statistical assessment of reliability and validity of measurement tool(s) (Quant. only) & 0.67 & 0.50 & 1 & I \\
\hline 10. Fit between stated research question and method of data collection (Quant. only) & 2.67 & 1 & 3 & l \\
\hline $\begin{array}{l}\text { 11. Fit between stated research question and format and content of data collection tool. } \\
\text { (Qual. only) }\end{array}$ & 2.46 & 2.27 & 2.25 & 3 \\
\hline 12.Fit between research question and method of analysis & 2.36 & 2.23 & 2.46 & 3 \\
\hline 13.Good justification for analytical method selected & 0.67 & 0.62 & 1 & 1 \\
\hline 14.Assessment of reliability of analytic process (Qual. only) & 1.38 & 0.91 & 1.17 & 1 \\
\hline 15.Evidence of user involvement in design & 0.13 & 0.23 & 0 & 0 \\
\hline 16.Strengths and limitations critically discussed & 1.53 & 1.31 & 1.54 & 1 \\
\hline Total score & 23.80 & 22.46 & 24.38 & 26 \\
\hline Percentage score & $52 \%$ & $50 \%$ & $53 \%$ & $58 \%$ \\
\hline
\end{tabular}




\begin{tabular}{|c|c|c|c|c|}
\hline \multirow[b]{2}{*}{ Item (Score 0 - 3) } & \multicolumn{4}{|c|}{ Theme 2: Types of family influence } \\
\hline & $\begin{array}{c}\text { 1.1/ Direct } \\
\text { or indirect } \\
\text { influence } \\
(n=22)\end{array}$ & $\begin{array}{l}\text { 1.2/ Positive or } \\
\text { negative } \\
\text { influence }(n=16)\end{array}$ & $\begin{array}{l}\text { 1.3/ Passive to } \\
\text { dominant } \\
\text { attitude }(n=9)\end{array}$ & $\begin{array}{l}\text { 2/ When family } \\
\text { members } \\
\text { influence the } \\
\text { decision- } \\
\text { making }(n=11)\end{array}$ \\
\hline 1. Explicit theoretical framework & 2.23 & 2,25 & 2,78 & 2,36 \\
\hline 2.Statement of aims/objectives in main body of report & 2.91 & 2,88 & 2,89 & 2,91 \\
\hline 3.Clear description of research setting & 2,50 & 2,63 & 2,33 & 2,36 \\
\hline 4.Evidence of sample size considered in terms of analysis & 1 & 0,88 & 0,67 & 1,09 \\
\hline 5.Representative sample of target group of a reasonable size & 2,14 & 2,13 & 2,22 & 2,09 \\
\hline 6.Description of procedure for data collection & 1,95 & 1,94 & 2,11 & 1,82 \\
\hline 7.Rationale for choice of data collection tool(s) & 0,73 & 0,94 & 1,11 & 1,18 \\
\hline 8.Detailed recruitment data & 1,29 & 1,33 & 1,38 & 0,91 \\
\hline 9.Statistical assessment of reliability and validity of measurement tool(s) (Quant. only) & 1 & 1 & 1 & 2 \\
\hline 10. Fit between stated research question and method of data collection (Quant. only) & 2,50 & 2,33 & 3 & 3 \\
\hline $\begin{array}{l}\text { 11. Fit between stated research question and format and content of data collection tool. } \\
\text { (Qual. only) }\end{array}$ & 2,21 & 2,31 & 2,38 & 2,30 \\
\hline 12.Fit between research question and method of analysis & 2,05 & 2,25 & 2,67 & 2,55 \\
\hline 13.Good justification for analytical method selected & 0,45 & 0,50 & 0,89 & 0,45 \\
\hline 14.Assessment of reliability of analytic process (Qual. only) & 1,05 & 1,08 & 1,25 & 1 \\
\hline 15.Evidence of user involvement in design & 0,18 & 0,19 & 0 & 0 \\
\hline 16.Strengths and limitations critically discussed & 1,41 & 1,44 & 1,56 & 1,27 \\
\hline Total score & 22,18 & 22,63 & 24,56 & 22,45 \\
\hline Percentage score & $49 \%$ & $50 \%$ & $54 \%$ & $50 \%$ \\
\hline
\end{tabular}




\begin{tabular}{|c|c|c|c|c|c|c|}
\hline \multirow[b]{2}{*}{ Item (Score 0 - 3) } & \multicolumn{6}{|c|}{ Theme 3: Factors contributing to family involvement } \\
\hline & $\begin{array}{c}1 / \\
\text { Illness } \\
\text { factors } \\
(\mathrm{n}=10)\end{array}$ & $\begin{array}{c}2 / \\
\text { Patients } \\
\text { factors } \\
(\mathrm{n}=12)\end{array}$ & $\begin{array}{c}3 / \\
\text { Family } \\
\text { factors } \\
(n=7)\end{array}$ & $\begin{array}{c}4 / \\
\text { Cultural } \\
\text { factors } \\
(n=12)\end{array}$ & $\begin{array}{c}5 / \\
\text { Medical } \\
\text { factors } \\
(\mathrm{n}=12)\end{array}$ & $\begin{array}{c}6 / \\
\text { Barriers to } \\
\text { FMs' } \\
\text { involvement } \\
(\mathrm{n}=4)\end{array}$ \\
\hline 1. Explicit theoretical framework & 2 & 2,25 & 2,14 & 2,33 & 2,50 & 2,50 \\
\hline 2.Statement of aims/objectives in main body of report & 2,70 & 2,83 & 2,71 & 2,83 & 2,92 & 3,00 \\
\hline 3.Clear description of research setting & 2,80 & 2,50 & 2,43 & 2,33 & 2,67 & 2,25 \\
\hline 4.Evidence of sample size considered in terms of analysis & 0,30 & 0,92 & 0,29 & 1,33 & 1 & 0,00 \\
\hline 5.Representative sample of target group of a reasonable size & 2,30 & 2,50 & 2,71 & 2,42 & 2,08 & 2,50 \\
\hline 6.Description of procedure for data collection & 1,90 & 1,75 & 1,71 & 2 & 2,08 & 1,75 \\
\hline 7.Rationale for choice of data collection tool(s) & 0,50 & 0,92 & 1,14 & 0,92 & 0,75 & 1,25 \\
\hline 8.Detailed recruitment data & 1,78 & 1,09 & 0,50 & 0,83 & 1,25 & 1,00 \\
\hline 9.Statistical assessment of reliability and validity of measurement tool(s) (Quant. only) & 1 & 1 & 2 & 1,40 & 0,67 & 2,00 \\
\hline 10. Fit between stated research question and method of data collection (Quant. only) & 2,33 & 2,13 & 2,67 & 1,80 & 2,67 & 2,50 \\
\hline $\begin{array}{l}\text { 11. Fit between stated research question and format and content of data collection } \\
\text { tool. (Qual. only) }\end{array}$ & 2,33 & 2,25 & 2,50 & 2,29 & 2,40 & 2,00 \\
\hline 12.Fit between research question and method of analysis & 2 & 2,17 & 2,57 & 2,08 & 2,00 & 2,25 \\
\hline 13.Good justification for analytical method selected & 0,90 & 0,50 & 0,43 & 0,50 & 0,50 & 0,00 \\
\hline 14.Assessment of reliability of analytic process (Qual. only) & 1,44 & 1 & 0,75 & 1 & 1,50 & 2,00 \\
\hline 15.Evidence of user involvement in design & 0,20 & 0,17 & 0,29 & 0,17 & 0,33 & 0,25 \\
\hline 16.Strengths and limitations critically discussed & 1,20 & 1,83 & 2 & 1,50 & 1,67 & 1,75 \\
\hline Total score & 22,80 & 22,50 & 22,71 & 22,50 & 23,83 & 22,75 \\
\hline Percentage score & $49 \%$ & $50 \%$ & $50 \%$ & $50 \%$ & $52 \%$ & $51 \%$ \\
\hline
\end{tabular}




\begin{tabular}{|c|c|c|}
\hline \multirow[b]{2}{*}{ Item $($ Score $0-3)$} & \multicolumn{2}{|c|}{ Theme 4: Family needs and preferences } \\
\hline & $\begin{array}{c}1 / \text { Need for } \\
\text { information }(n=5)\end{array}$ & $2 /$ Need to be involved $(n=11)$ \\
\hline 1. Explicit theoretical framework & 2 & 2,27 \\
\hline 2.Statement of aims/objectives in main body of report & 3 & 2,91 \\
\hline 3.Clear description of research setting & 2.40 & 2,55 \\
\hline 4.Evidence of sample size considered in terms of analysis & 0.60 & 1,09 \\
\hline 5.Representative sample of target group of a reasonable size & 2 & 2,27 \\
\hline 6.Description of procedure for data collection & 2 & 2,09 \\
\hline 7.Rationale for choice of data collection tool(s) & 1.60 & 0,91 \\
\hline 8.Detailed recruitment data & 1.40 & 1 \\
\hline $\begin{array}{l}\text { 9.Statistical assessment of reliability and validity of measurement tool(s) (Quant. } \\
\text { only) }\end{array}$ & 0.50 & 1,50 \\
\hline 10. Fit between stated research question and method of data collection (Quant. only) & 1 & 1,50 \\
\hline $\begin{array}{l}\text { 11. Fit between stated research question and format and content of data collection } \\
\text { tool. (Qual. only) }\end{array}$ & 2.33 & 2,44 \\
\hline 12.Fit between research question and method of analysis & 1.40 & 2,18 \\
\hline 13.Good justification for analytical method selected & 0.60 & 0,45 \\
\hline 14.Assessment of reliability of analytic process (Qual. only) & 0.67 & 1,22 \\
\hline 15.Evidence of user involvement in design & 0.80 & 0,18 \\
\hline 16.Strengths and limitations critically discussed & 1.20 & 1,36 \\
\hline Total score & 21.40 & 22,73 \\
\hline Percentage score & $48 \%$ & $50 \%$ \\
\hline
\end{tabular}




\begin{tabular}{|c|c|c|}
\hline \multirow[b]{2}{*}{ Item $($ Score 0 - 3) } & \multicolumn{2}{|c|}{ Theme 5: Decision making patterns } \\
\hline & $\begin{array}{l}\text { 1/ Family members' exclusion } \\
\text { from decision-making }(n=15)\end{array}$ & $\begin{array}{l}\text { 2/ Family members' inclusion } \\
\text { in decision-making }(n=5)\end{array}$ \\
\hline 1. Explicit theoretical framework & 2.27 & 2.40 \\
\hline 2.Statement of aims/objectives in main body of report & 2.93 & 3 \\
\hline 3.Clear description of research setting & 2.80 & 2.40 \\
\hline 4.Evidence of sample size considered in terms of analysis & 0.93 & 0.40 \\
\hline 5.Representative sample of target group of a reasonable size & 2.27 & 2 \\
\hline 6.Description of procedure for data collection & 2.00 & 2 \\
\hline 7.Rationale for choice of data collection tool(s) & 1.07 & 1 \\
\hline 8.Detailed recruitment data & 0.93 & 1.40 \\
\hline $\begin{array}{l}\text { 9.Statistical assessment of reliability and validity of measurement tool(s) (Quant. } \\
\text { only) }\end{array}$ & 0.50 & 0.50 \\
\hline 10. Fit between stated research question and method of data collection (Quant. only) & 2 & 1.50 \\
\hline $\begin{array}{l}\text { 11. Fit between stated research question and format and content of data collection } \\
\text { tool. (Qual. only) }\end{array}$ & 2.45 & 2.50 \\
\hline 12.Fit between research question and method of analysis & 2.33 & 2 \\
\hline 13.Good justification for analytical method selected & 0.53 & 1 \\
\hline 14.Assessment of reliability of analytic process (Qual. only) & 1.09 & 2 \\
\hline 15.Evidence of user involvement in design & 0.33 & 1 \\
\hline 16.Strengths and limitations critically discussed & 1.33 & 0.80 \\
\hline Total score & 22.93 & 22.80 \\
\hline Percentage score & $51 \%$ & $50 \%$ \\
\hline
\end{tabular}


Appendix 3. Summary table of the included studies

\begin{tabular}{|c|c|c|c|c|c|}
\hline $\begin{array}{l}\text { Authors, Year; } \\
\text { Country }\end{array}$ & Design and Methods & $\begin{array}{c}\text { Population, } \\
\text { Recruitment location, } \\
\text { type of treatment } \\
\text { choice }\end{array}$ & Objective & Measures & Results \\
\hline \multicolumn{6}{|c|}{$\begin{array}{l}\text { Studies identified and included through database } \\
\text { research }\end{array}$} \\
\hline $\begin{array}{l}\text { [12] } \\
\text { Visser et al., } 2009 \\
\text { Netherlands }\end{array}$ & $\begin{array}{l}\text { Design: Cross- } \\
\text { sectional and } \\
\text { retrospective study } \\
\text { Method: Qualitative }\end{array}$ & $\begin{array}{l}\text { Sample: } 14 \text { patients } \\
\text { Age: Starting dialysis: } \\
\text { mean age }=72.6, \mathrm{SD}= \\
7.7 \\
\text { Not starting dialysis: } \\
\text { mean age = } 82.5, \mathrm{SD}= \\
6.0 \\
\text { Gender: Starting } \\
\text { dialysis: } 63 \% \text { are women } \\
\text { Not starting dialysis: } \\
17 \% \text { are women } \\
\text { Close others } \\
\text { characteristics: No } \\
\text { close others were } \\
\text { included in this study } \\
\text { Recruitment: Renal } \\
\text { Failure outpatient clinic } \\
\text { or dialysis center at a } \\
\text { University medical } \\
\text { center } \\
\text { Discipline: Nephrology } \\
\text { (CKD) } \\
\text { Choice: Dialysis }\end{array}$ & $\begin{array}{l}\text { The place } \\
\text { of family in } \\
\text { treatment } \\
\text { decision is: } \\
\text { Not a main } \\
\text { objective of } \\
\text { the study }\end{array}$ & $\begin{array}{l}\text { Interviews: } \\
\text { Aim: Revealing the } \\
\text { patients' considerations } \\
\text { in treatment decision- } \\
\text { making. } \\
\text { Questions about: the } \\
\text { information they were } \\
\text { given by the medical } \\
\text { staff about dialysis, } \\
\text { their current health } \\
\text { status, their history of } \\
\text { illness and their process } \\
\text { of diagnosis. } \\
\text { Follow-up questions } \\
\text { were used to elicit more } \\
\text { information. }\end{array}$ & $\begin{array}{l}\text { The people choosing not to start } \\
\text { dialysis were more often older, men } \\
\text { and widows/widowers. } \\
\text { For some participants, having to take } \\
\text { care of a family member who was } \\
\text { sick influenced their choice towards } \\
\text { dialysis. }\end{array}$ \\
\hline
\end{tabular}




\begin{tabular}{|c|c|c|c|c|c|}
\hline $\begin{array}{l}\text { [23] } \\
\text { Blumenthal- } \\
\text { Barby et al., } 2015 \\
\text { USA }\end{array}$ & $\begin{array}{l}\text { Design: } \\
\text { Retrospective, cross- } \\
\text { sectional and } \\
\text { longitudinal study } \\
\text { Methods: Mixed }\end{array}$ & $\begin{array}{l}\text { Sample: } 45 \text { participants } \\
\text { (15 candidates for left } \\
\text { ventricular assist device } \\
\text { placement, } 15 \text { patients } \\
\text { and } 15 \text { close others). } \\
\text { Age: } \\
\text { Candidates for left } \\
\text { ventricular assist device } \\
\text { placement: mean age = } \\
\text { 54, ranging from } 34 \text { to } \\
74 \\
\text { Patients, mean age = 60, } \\
\text { ranging from } 33 \text { to } 74 \\
\text { Close others: mean age }= \\
\text { 59, ranging from } 33 \text { to } \\
74 \\
\text { Gender: Candidates for } \\
\text { left ventricular assist } \\
\text { device placement: } 87 \% \\
\text { are men } \\
\text { Patients: } 73 \% \text { are men } \\
\text { Close others: } 64 \% \text { are } \\
\text { men } \\
\text { Close others } \\
\text { characteristics: } \\
\text { Caregivers: Family } \\
\text { member or significant } \\
\text { other } \\
\text { Recruitment: LVAD } \\
\text { clinic/hospital roster } \\
\text { Discipline: Cardiology } \\
\text { Choice: LVAD }\end{array}$ & \begin{tabular}{|l}
$\begin{array}{l}\text { The place } \\
\text { of family in } \\
\text { treatment } \\
\text { decision is: }\end{array}$ \\
A main \\
objective of \\
the study
\end{tabular} & $\begin{array}{l}\text { Structured interviews: } \\
\text { - } \begin{array}{l}\text { Perceptions of } \\
\text { options }\end{array} \\
\text { - } \begin{array}{l}\text { Outcomes and } \\
\text { probabilities }\end{array} \\
\text { - } \quad \text { Values in decision- } \\
\text { making } \\
\text { - } \quad \begin{array}{l}\text { Degree of decision- } \\
\text { making }\end{array} \\
\text { - Difficulties and } \\
\text { factors contributing } \\
\text { to difficulties } \\
\text { - Usual and preferred } \\
\text { decision-making } \\
\text { roles } \\
\text { - Decisional barriers } \\
\text { and facilitators. } \\
\text { Decisional Regret } \\
\text { Scale: 5-point Likert } \\
\text { scale. Assesses distress } \\
\text { or remorse after a } \\
\text { healthcare decision. }\end{array}$ & $\begin{array}{l}\text { The patients needed: } \\
\text { - To talk with other patients and } \\
\text { their families } \\
\text { - } \quad \text { To trust their physicians } \\
\text { - } \quad \text { An involved caregiver } \\
\text { - } \quad \text { This caregiver to synthesize, } \\
\text { translate and memorize the } \\
\text { information } \\
\text { The caregivers needed: } \\
\text { - Information on their lifestyle } \\
\text { - To know what their } \\
\text { responsibilities are } \\
\text { The patients wanted to live longer, } \\
\text { especially for their family members } \\
\text { (FMs). Family was an important } \\
\text { value to them. } \\
\text { The patients perceived that decision- } \\
\text { making was often deferred to the } \\
\text { doctors and did not feel like they } \\
\text { had a choice. }\end{array}$ \\
\hline
\end{tabular}




\begin{tabular}{|c|c|c|c|c|c|}
\hline & & placement & & & \\
\hline $\begin{array}{l}{[24]} \\
\text { Chong et al., } \\
2012 \\
\text { Singapour }\end{array}$ & $\begin{array}{l}\text { Design: Retrospective } \\
\text { and cross-sectional } \\
\text { study } \\
\text { Methods: Qualitative } \\
\text { (Analysis of case } \\
\text { records) }\end{array}$ & $\begin{array}{l}\text { Sample: } 55 \text { patients who } \\
\text { died in the ward } \\
\text { Age: mean age }=65, \\
\text { ranging from } 34 \text { to } 85 \\
\text { Gender: } 47 \% \text { are men } \\
\text { Close others } \\
\text { characteristics: No } \\
\text { close others included in } \\
\text { the study } \\
\text { Recruitment: NS } \\
\text { Discipline: Cancer } \\
\text { Choice: Initial treatment } \\
\text { (NS) }\end{array}$ & 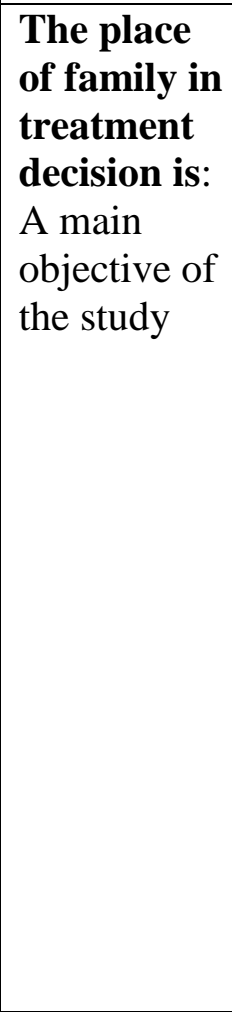 & $\begin{array}{l}\text { Qualitative } \\
\text { retrospective study } \\
\text { based on notes from the } \\
\text { patients' outpatients/ } \\
\text { ambulatory care and } \\
\text { inpatients' case } \\
\text { management records } \\
\text { written by the medical } \\
\text { team. }\end{array}$ & $\begin{array}{l}61 \% \text { of patients were included in the } \\
\text { discussions on treatment choice. } \\
\text { Some patients were not told their } \\
\text { diagnosis (request to keep the } \\
\text { diagnosis a secret from the patient } \\
\text { was initiated by the families). } \\
\text { Advanced age was associated with } \\
\text { the patients' non-involvement at first } \\
\text { diagnosis disclosure and families } \\
\text { requesting that the diagnosis be not } \\
\text { disclosed to the patient. } \\
\text { In } 65 \% \text { of the cases the family was } \\
\text { included in the initial treatment } \\
\text { decision-making. The families were } \\
\text { more involved in the decision- } \\
\text { making process when the patients } \\
\text { were older, did not speak English } \\
\text { and when non-curative treatments } \\
\text { were considered. }\end{array}$ \\
\hline $\begin{array}{l}{[25]} \\
\text { Del Piccolo et al., } \\
2014 \\
\text { Italy }\end{array}$ & $\begin{array}{l}\text { Design: Cross- } \\
\text { sectional study } \\
\text { Methods: Mixed }\end{array}$ & $\begin{array}{l}\text { Sample: } 70 \text { patients } \\
\text { including } 48 \text { with one or } \\
\text { two relatives } \\
\text { Age: Patients } \\
\text { accompanied: mean age } \\
=58 \text {, ranging from } 41 \text { to } \\
68 \text { years } \\
\text { Patients not } \\
\text { accompanied: mean age } \\
=55 \text {, ranging from } 31 \text { to }\end{array}$ & $\begin{array}{l}\text { The place } \\
\text { of family in } \\
\text { treatment } \\
\text { decision is: } \\
\text { Not a main } \\
\text { objective of } \\
\text { study }\end{array}$ & $\begin{array}{l}\text { Questionnaires } \\
\text { completed before the } \\
\text { consultation: } \\
\text { - Sociodemographic } \\
\text { data } \\
\text { - } \quad \text { State Anxiety } \\
\text { Inventory (STAI- } \\
\text { X1) } \\
\text { - General Health } \\
\text { Questionnaire }\end{array}$ & $\begin{array}{l}\text { The patients who came to the } \\
\text { consultation with a companion } \\
\text { preferred to have a more passive role } \\
\text { in the consultation. } \\
\text { The close others and patients with } \\
\text { and without close others during the } \\
\text { consultations reported low levels of } \\
\text { shared decision making but were } \\
\text { satisfied with their treatments. }\end{array}$ \\
\hline
\end{tabular}




\begin{tabular}{|c|c|c|c|c|c|}
\hline & & $\begin{array}{l}75 \\
\text { Gender: Patients: all } \\
\text { women } \\
\text { Close others: } 58 \% \text { are } \\
\text { men } \\
\text { Close others } \\
\text { characteristics: } \\
\text { Relatives: Husbands } \\
\text { (48\%), children (23\%; } \\
6 \% \text { sons and 17\% } \\
\text { daughters), sister (10\%), } \\
\text { mother (2\%), friend } \\
\text { (8\%), others (10\%). } \\
\text { Recruitment: Out- } \\
\text { patient clinic of the } \\
\text { Medical Oncology Unit } \\
\text { of the Hospital Trust of } \\
\text { Verona } \\
\text { Discipline: Breast } \\
\text { cancer } \\
\text { Choice: Treatments } \\
\text { (surgery and/or } \\
\text { chemotherapy or } \\
\text { radiotherapy or } \\
\text { hormonotherapy) }\end{array}$ & & $\begin{array}{l}\text { (GHQ-12) } \\
\text { - } \quad \text { Patient Health } \\
\text { Questionnaire } \\
\text { Depression scale } \\
\text { (PHQ-9) } \\
\text { - } \quad \text { Control Preference } \\
\text { Scale (CPS) } \\
\text { - Decision Self } \\
\text { Efficacy Scale } \\
\text { (DSES) } \\
\text { Audio taped } \\
\text { consultations then } \\
\text { transcribed and coded } \\
\text { by content. } \\
\text { Questionnaires } \\
\text { completed after the } \\
\text { consultation: } \\
\text { - Shared Decision } \\
\text { Making } \\
\text { Questionnaire } \\
\text { (SDM-Q) } \\
\text { - Satisfaction with } \\
\text { Decision Scale } \\
\text { (SWD) }\end{array}$ & $\begin{array}{l}\text { Close others asked significantly } \\
\text { fewer questions than patients and } \\
\text { gave priority to the topics important } \\
\text { to the patients. } \\
\text { During the consultations, questions } \\
\text { asked by the close others aimed to } \\
\text { obtain new information (53\% of the } \\
\text { questions) or to help understand the } \\
\text { information (38\%). } \\
\text { The relatives had different roles } \\
\text { during the consultations with regards } \\
\text { to asking question: } \\
\text { - a shared role with the patient } \\
\text { (67\%), } \\
\text { - a passive role (12\%), } \\
\text { - an active advocate's role ( } 21 \% \text { ). } \\
\text { Differences in satisfaction with } \\
\text { treatment decision between close } \\
\text { others and patients: } \\
\text { - } 50 \% \text { reported a similar score } \\
\text { (among them 92\% agreed on a } \\
\text { positive evaluation) } \\
50 \% \text { of the patients' evaluations } \\
\text { were more negative than their } \\
\text { close others' }\end{array}$ \\
\hline $\begin{array}{l}{[26]} \\
\text { Dellon et al., } \\
2012\end{array}$ & $\begin{array}{l}\text { Design: Retrospective } \\
\text { and cross-sectional } \\
\text { study }\end{array}$ & $\begin{array}{l}\text { Sample: } 36 \text { caregivers } \\
\text { of } 36 \text { patients who died } \\
\text { at a mean age of } 24\end{array}$ & $\begin{array}{l}\text { The place } \\
\text { of family in } \\
\text { treatment }\end{array}$ & $\begin{array}{l}\text { Semi-structured } \\
\text { interviews } \\
\text { About the end-of-life }\end{array}$ & $\begin{array}{l}61 \% \text { of caregivers never discussed } \\
\text { intensive treatments with the } \\
\text { physician. } 50 \% \text { of patients talked }\end{array}$ \\
\hline
\end{tabular}




\begin{tabular}{|c|c|c|c|c|c|}
\hline USA & Methods: Qualitative & $\begin{array}{l}\text { Age: } \text { mean age }=57, \\
\text { ranging from } 32 \text { to } 82 \\
\text { Gender: } 89 \% \text { are } \\
\text { women } \\
\text { Close others } \\
\text { characteristics: } 86 \% \text { are } \\
\text { parents, } 6 \% \text { partners; } 3 \% \\
\text { siblings, } 3 \% \\
\text { grandparents; } 3 \% \text { friends } \\
\text { Recruitment: NS } \\
\text { Discipline: Cystic } \\
\text { Fibrosis } \\
\text { Choice: Intensive } \\
\text { treatments }\end{array}$ & $\begin{array}{l}\text { decision is: } \\
\text { A main } \\
\text { objective of } \\
\text { study }\end{array}$ & $\begin{array}{l}\text { experience of the } \\
\text { corresponding patients. } \\
\text { Close-ended questions } \\
\text { addressing whether and } \\
\text { when discussions about } \\
\text { intensive treatment } \\
\text { preferences occurred, } \\
\text { whether or not patients } \\
\text { participated in these } \\
\text { discussions, and } \\
\text { whether patient } \\
\text { preferences were } \\
\text { upheld. }\end{array}$ & $\begin{array}{l}\text { about their preferences with their } \\
\text { caregiver. } \\
39 \% \text { of patients were involved in } \\
\text { decision-making with their } \\
\text { physician. } \\
\text { When patients did not participate, } \\
\text { FMs were less certain that patients' } \\
\text { preferences were upheld. }\end{array}$ \\
\hline $\begin{array}{l}\text { [27] } \\
\text { Hall et al., } 2012 \\
\text { USA }\end{array}$ & $\begin{array}{l}\text { Design: Retrospective } \\
\text { and cross-sectional } \\
\text { study } \\
\text { Method: Qualitative }\end{array}$ & $\begin{array}{l}\text { Sample: } 38 \text { patients } \\
\text { Age: NS } \\
\text { Gender: NS } \\
\text { Close others } \\
\text { characteristics: No } \\
\text { close others included in } \\
\text { the study } \\
\text { Recruitment: General } \\
\text { Surgery Clinic (VA } \\
\text { Medical Center in } \\
\text { Pittsburgh) } \\
\text { Discipline: No specific } \\
\text { illness } \\
\text { Choice: Surgery }\end{array}$ & $\begin{array}{l}\text { The place } \\
\text { of family in } \\
\text { treatment } \\
\text { decision is: } \\
\text { Not a main } \\
\text { objective of } \\
\text { the study }\end{array}$ & $\begin{array}{l}\text { Semi-structured } \\
\text { phone interviews } \\
27 \text { open-ended } \\
\text { questions exploring } \\
\text { how and when they } \\
\text { made their decision, } \\
\text { their sources of } \\
\text { information, who } \\
\text { influenced or helped in } \\
\text { the decision-making } \\
\text { and their opinion on a } \\
\text { computer-based tool } \\
\text { used to facilitate the } \\
\text { processes of informed } \\
\text { consent in the Medical } \\
\text { Center }\end{array}$ & $\begin{array}{l}\text { More than half of the participants } \\
\text { described their families as a source } \\
\text { of information that helped them } \\
\text { during the decision-making process. } \\
1 / 5 \text { described them as their primary } \\
\text { source of information. } \\
\text { Assistance in decision-making was } \\
\text { rendered by the patients' primary } \\
\text { care physicians or other non-surgical } \\
\text { staff provided as well as family, } \\
\text { friends and significant others. }\end{array}$ \\
\hline $\begin{array}{l}{[28]} \\
\text { Harrington and }\end{array}$ & $\begin{array}{l}\text { Design: Cross- } \\
\text { sectional study }\end{array}$ & $\begin{array}{l}\text { Sample: } 24 \text { transplant } \\
\text { recipients }\end{array}$ & $\begin{array}{l}\text { The place } \\
\text { of family in }\end{array}$ & $\begin{array}{l}\text { Semi-structured } \\
\text { interviews: }\end{array}$ & $\begin{array}{l}\text { Treatment choice was influenced by } \\
\text { the trust in the staff. }\end{array}$ \\
\hline
\end{tabular}




\begin{tabular}{|c|c|c|c|c|c|}
\hline $\begin{array}{l}\text { Morgan, } 2016 \\
\text { UK }\end{array}$ & Method: Qualitative & $\begin{array}{l}\text { Age: } \text { mean age }=\mathrm{NS} \text {, } \\
\text { ranging from } 27 \text { to } 68 \\
\text { Gender: NS } \\
\text { Close others } \\
\text { characteristics: No } \\
\text { close others included in } \\
\text { the study } \\
\text { Recruitment: } 8 \\
\text { hospitals } \\
\text { Discipline: Chronic } \\
\text { Kidney Disease } \\
\text { Choice: } \\
\text { Immunosuppressant } \\
\text { medication for kidney } \\
\text { transplant patients }\end{array}$ & $\begin{array}{l}\text { treatment } \\
\text { decision is: } \\
\text { Not a main } \\
\text { objective in } \\
\text { the study }\end{array}$ & $\begin{array}{l}\text { Interviews included: } \\
\text { sharing the 'story' of } \\
\text { their renal failure and } \\
\text { kidney transplant(s), } \\
\text { issues that the } \\
\text { participants raised } \\
\text { during that first part, } \\
\text { the patients' attitude } \\
\text { towards risk, personal } \\
\text { priorities, views on the } \\
\text { biomarker test and } \\
\text { what they would do if } \\
\text { the test indicated they } \\
\text { were 'tolerant' and } \\
\text { could have their } \\
\text { immunosuppressant } \\
\text { medication reduced. }\end{array}$ & $\begin{array}{l}\text { The patients talked about risky } \\
\text { treatments with their families. Their } \\
\text { FMs were much more 'risk-averse' } \\
\text { than they were. } \\
\text { There was not much family } \\
\text { negotiation regarding } \\
\text { immunosuppressant treatments when } \\
\text { the graft came from a family } \\
\text { member. In fact, family negotiation } \\
\text { was more a result of the necessity to } \\
\text { discuss risks within relationships. }\end{array}$ \\
\hline $\begin{array}{l}\text { [29] } \\
\text { Hirpara et al., } \\
2016 \\
\text { Canada }\end{array}$ & $\begin{array}{l}\text { Design: Cross- } \\
\text { sectional and } \\
\text { retrospective study } \\
\text { Method: Qualitative }\end{array}$ & $\begin{array}{l}\text { Sample: } 20 \text { patients } \\
\text { Age: mean age }=71.5, \\
\text { ranging from } 42 \text { to } 88 \\
\text { Gender: } 55 \% \text { are men } \\
\text { Close others } \\
\text { characteristics: No } \\
\text { close others included in } \\
\text { this study } \\
\text { Recruitment: } \\
\text { Gastrointestinal } \\
\text { Oncology Clinic at } \\
\text { Princess Margaret } \\
\text { Cancer Centre and } \\
\text { Toronto Western } \\
\text { Hospital }\end{array}$ & $\begin{array}{l}\text { The place } \\
\text { of family in } \\
\text { treatment } \\
\text { decision is: } \\
\text { Not a main } \\
\text { objective of } \\
\text { the study }\end{array}$ & $\begin{array}{l}\text { Semi-structured } \\
\text { interviews: } \\
\text { Topics explored: } \\
\text { - } \text { Healthcare } \\
\text { experience since the } \\
\text { diagnosis } \\
\text { - } \text { Open-ended } \\
\text { questions on: } \\
\text { O Perceptions of } \\
\text { choice } \\
\circ \quad \text { Preferences for } \\
\text { participation in } \\
\text { decision-making } \\
\circ \quad \text { Factors that } \\
\text { helped or }\end{array}$ & $\begin{array}{l}\text { Three major themes: } \\
\text { - } \quad \begin{array}{l}\text { The role of family and social } \\
\text { support }\end{array} \\
\text { - } \quad \begin{array}{l}\text { Facilitators and barriers to } \\
\text { decision-making }\end{array} \\
\text { - } \quad \begin{array}{l}\text { Lack of choice and control in } \\
\text { decision-making }\end{array} \\
\text { FMs could: } \\
\text { - Give their opinion on treatments } \\
\text { or collaborate with the patients } \\
\text { regarding their treatment choice. } \\
\text { - Translate the patient's words to } \\
\text { the staff and vice versa } \\
\text { - Provide support to the patients }\end{array}$ \\
\hline
\end{tabular}




\begin{tabular}{|c|c|c|c|c|c|}
\hline & & $\begin{array}{l}\text { Discipline: Cancer } \\
\text { (Colorectal) } \\
\text { Choice: Surgery }\end{array}$ & & $\begin{array}{l}\text { hindered } \\
\text { decision-making }\end{array}$ & $\begin{array}{l}\text { (emotional, practical and } \\
\text { psychological). This could } \\
\text { alleviate the burden of decision- } \\
\text { making and improve the } \\
\text { patient's experience } \\
\text { Family support and trust in the } \\
\text { medical staff acted as facilitators to } \\
\text { decision-making. However, the } \\
\text { patients felt limited sense of control } \\
\text { over decisions. }\end{array}$ \\
\hline $\begin{array}{l}{[32]} \\
\text { Ito et al., } 2010 \\
\text { Japan }\end{array}$ & $\begin{array}{l}\text { Design: Descriptive } \\
\text { and cross-sectional } \\
\text { study } \\
\text { Method: Quantitative }\end{array}$ & $\begin{array}{l}\text { Sample: } 128 \text { patients } \\
\text { and 41 FMs } \\
\text { Age: Patients: mean age } \\
=59.5, \text { SD = } 14.4 \\
\text { FMs: mean age = } 54.3 \text {, } \\
\text { SD = } 12.2 \\
\text { Gender: Patients: } 63.3 \% \\
\text { are men } \\
\text { FMs: } 82.9 \% \text { are women } \\
\text { Close others } \\
\text { characteristics: } 71 \% \text { are } \\
\text { partners, } 20 \% \text { children, } \\
5 \% \text { parents, } 2 \% \\
\text { daughters- or sons-in- } \\
\text { law, } 2 \% \text { siblings. } \\
\text { Recruitment: } \\
\text { Yamaguchi University } \\
\text { Hospital } \\
\text { and Yamaguchi Grand } \\
\text { Medical Center in } \\
\text { western Japan }\end{array}$ & $\begin{array}{l}\text { The place } \\
\text { of family in } \\
\text { treatment } \\
\text { decision is: } \\
\text { A main } \\
\text { objective of } \\
\text { the study }\end{array}$ & $\begin{array}{l}\text { The Patient and } \\
\text { Family Health Care } \\
\text { Decision-making } \\
\text { Preferences } \\
\text { Questionnaire (PFQ) } \\
\text { Three parts: } \\
\text { - } \quad \text { Socio-demographic } \\
\text { variables } \\
\text { - } \quad 17 \text { items relating to } \\
\text { the current } \\
\text { hospitalization } \\
\text { - The participants' } \\
\text { perceptions of the } \\
\text { consultation with } \\
\text { FMs for significant } \\
\text { life incidents; the } \\
\text { extent of and reason } \\
\text { for family decision- } \\
\text { making for } \\
\text { competent patients; } \\
\text { whether health }\end{array}$ & $\begin{array}{l}\text { All the patients and FMs thought } \\
\text { they should be involved in the } \\
\text { decision-making process. } \\
\text { The patients wanted to: participate } \\
\text { in the discussions regarding their } \\
\text { treatment, give their opinions, be } \\
\text { asked for their consent, have an } \\
\text { opportunity to choose a treatment } \\
\text { when multiple options are available, } \\
\text { be told the reasons for their } \\
\text { treatment, have their opinions } \\
\text { respected by health professionals. } \\
\text { The FMs wanted to: be asked for } \\
\text { their consent regarding the patients' } \\
\text { treatments, be explained the reasons } \\
\text { for a treatment, have an opportunity } \\
\text { to choose their treatment when } \\
\text { several options were available and } \\
\text { have their opinions respected by the }\end{array}$ \\
\hline
\end{tabular}




\begin{tabular}{|c|c|c|c|c|c|}
\hline & & $\begin{array}{l}\text { Discipline: NS } \\
\text { Choice: NS }\end{array}$ & & $\begin{array}{l}\text { professionals } \\
\text { should reveal } \\
\text { information if the } \\
\text { family disagreed; } \\
\text { and the decision- } \\
\text { making preferences } \\
\text { for competent } \\
\text { patients } \\
\text { The questionnaire was } \\
\text { developed for the } \\
\text { present study (4 items } \\
\text { were taken from } \\
\text { another scale). } \\
\text { The questionnaire was } \\
\text { piloted with } 10 \text { healthy } \\
\text { adults. The validity and } \\
\text { reliability of the PFQ } \\
\text { was not confirmed. }\end{array}$ & $\begin{array}{l}\text { staff. } \\
\text { More than half of the patients did } \\
\text { not consider that their families } \\
\text { should make the decision when the } \\
\text { patients are competent. } \\
\text { Most patients and FMs thought that } \\
\text { the patients should make the } \\
\text { decision after consulting both their } \\
\text { families and their physicians. } \\
\text { The relationship with the staff was } \\
\text { very important. } \\
\text { There were similarities but also } \\
\text { differences between the patients' } \\
\text { wishes and those of their families. }\end{array}$ \\
\hline $\begin{array}{l}{[33]} \\
\text { Ivarsson, } \\
\text { Ekmehag and } \\
\text { Sjöberg, } 2014 \\
\text { Sweden }\end{array}$ & $\begin{array}{l}\text { Design: Cross- } \\
\text { sectional and } \\
\text { retrospective study } \\
\text { Method: Qualitative }\end{array}$ & $\begin{array}{l}\text { Sample: } 15 \text { close others } \\
\text { Age: mean age }=51 \text {, } \\
\text { range } 36-65 \text { years } \\
\text { Gender: } 8 \text { women and } 7 \\
\text { men } \\
\text { Close others } \\
\text { characteristics: } 60 \% \text { are } \\
\text { partners, } 20 \% \text { mothers, } \\
20 \% \text { children } \\
\text { Recruitment: Skane } \\
\text { hospital } \\
\text { Discipline: Surgery } \\
\text { Choice: Heart or lung } \\
\text { transplantation }\end{array}$ & $\begin{array}{l}\text { The place } \\
\text { of family in } \\
\text { treatment } \\
\text { decision is: } \\
\text { Not a main } \\
\text { objective of } \\
\text { the study }\end{array}$ & $\begin{array}{l}\text { Semi-directive } \\
\text { interviews: } \\
\text { Conversational } \\
\text { approach. The } \\
\text { participants were first } \\
\text { asked about their } \\
\text { experience with } \\
\text { information while } \\
\text { waiting for the } \\
\text { transplantation. } \\
\text { Followed by a question } \\
\text { about their experience } \\
\text { of social support during } \\
\text { that same time period. }\end{array}$ & $\begin{array}{l}\text { Three main themes: } \\
\text { - "Navigate specific } \\
\text { circumstances" } \\
\text { - "Facilitating throughout the } \\
\text { transplantation journey" } \\
\text { - "Experiences of strength and } \\
\text { weakness of information and } \\
\text { support." } \\
\text { The relatives wanted the patients to } \\
\text { be the ones to make the final } \\
\text { decision because they did not want } \\
\text { to feel guilty in case the } \\
\text { consequences were bad. They } \\
\text { provided physical, psychological }\end{array}$ \\
\hline
\end{tabular}




\begin{tabular}{|c|c|c|c|c|c|}
\hline & & & & $\begin{array}{l}\text { Follow-up questions for } \\
\text { clarification and to } \\
\text { keep the conversation } \\
\text { going. }\end{array}$ & $\begin{array}{l}\text { and social support to the patients. } \\
\text { FMs were happy with the } \\
\text { information they received from the } \\
\text { healthcare teams but also sought } \\
\text { information inside and outside the } \\
\text { healthcare system. They could also } \\
\text { feel uninformed and unsupported at } \\
\text { time by the staff. }\end{array}$ \\
\hline $\begin{array}{l}{[34]} \\
\text { Jordan et al., } \\
2013 \\
\text { USA/Argentina }\end{array}$ & $\begin{array}{l}\text { Design: Cross- } \\
\text { sectional and } \\
\text { longitudinal study } \\
\text { Method: Quantitative }\end{array}$ & $\begin{array}{l}\text { Sample: } 99 \text { patients (55 } \\
\text { had cancer while } 44 \text { had } \\
\text { chronic obstructive } \\
\text { pulmonary disease } \\
\text { (COPD)) } \\
\text { Age: COPD patients: } \\
\text { mean age = 60, SD = } 14 \\
\text { months } \\
\text { Cancer patients: mean } \\
\text { age = 58, SD = } 113 \\
\text { months } \\
\text { Gender: COPD patients: } \\
54.6 \% \text { are women } \\
\text { Cancer patients: } 52.3 \% \\
\text { are women } \\
\text { Close others } \\
\text { characteristics: No } \\
\text { close others were } \\
\text { included in this study } \\
\text { Recruitment: British } \\
\text { Hospital and the } \\
\text { Sanatorio Güemes } \\
\text { Private Hospital in }\end{array}$ & $\begin{array}{l}\text { The place } \\
\text { of family in } \\
\text { treatment } \\
\text { decision is: } \\
\text { Not a main } \\
\text { objective of } \\
\text { the study }\end{array}$ & $\begin{array}{l}\text { Questionnaire: } \\
30 \text { items about "their } \\
\text { preferences regarding } \\
\text { truth-telling } \\
\text { participation in the } \\
\text { decision-making } \\
\text { process, and desire for } \\
\text { information regarding } \\
\text { their illness", pilot- } \\
\text { tested in } 15 \text { patients } \\
\text { beforehand. } \\
\text { Answers audio- } \\
\text { recorded. }\end{array}$ & $\begin{array}{l}\text { Less than half of the participants did } \\
\text { not want their families to be told } \\
\text { about the severity of their illness. } \\
40 \% \text { of the patients wanted to make } \\
\text { the decision with their physicians } \\
\text { alone while } 33 \% \text { wanted to involve } \\
\text { both their families and their } \\
\text { physicians in the process. } \\
\text { If their families and the physicians } \\
\text { disagreed, } 77 \% \text { of patients would } \\
\text { have listened to the doctors' } \\
\text { recommendations. Only } 5 \% \text { would } \\
\text { have considered their families' } \\
\text { choices as relevant. }\end{array}$ \\
\hline
\end{tabular}




\begin{tabular}{|c|c|c|c|c|c|}
\hline & & $\begin{array}{l}\text { Buenos Aires } \\
\text { Discipline: Oncology } \\
\text { and Pneumology } \\
\text { Choice: Treatment, NS }\end{array}$ & & & \\
\hline $\begin{array}{l}{[36]} \\
\text { Laidsaar-Powell } \\
\text { et al., } 2016 \\
\text { Australia }\end{array}$ & $\begin{array}{l}\text { Design: Cross- } \\
\text { sectional and } \\
\text { retrospective study } \\
\text { Method: Qualitative }\end{array}$ & $\begin{array}{l}\text { Sample: } 84 \text { participants } \\
\text { (including } 30 \text { patients, } \\
33 \text { FMs, } 11 \text { oncologists } \\
\text { and } 10 \text { nurses) } \\
\text { Age: Patients: mean age } \\
=56 \text {, ranging from } 36 \text { to } \\
69 \\
\text { FMs: mean age }=54, \\
\text { ranging from } 39 \text { to } 61 \\
\text { Oncologists: mean age }= \\
50, \text { ranging from } 36 \text { to } \\
69 \\
\text { Nurses: mean age }=48, \\
\text { ranging from } 39 \text { to } 61 \\
\text { Gender: } \\
\text { Patients: } 50 \% \text { are men } \\
\text { (15 vs. } 15) \\
\text { FMs: } 39 \% \text { are men (13 } \\
\text { vs. } 20) \\
\text { Oncologists: } 73 \% \text { are } \\
\text { men (8 vs. } 3) \\
\text { Nurses: } 10 \% \text { are men (1 } \\
\text { vs. 9) } \\
\text { Close others } \\
\text { characteristics: } 75,8 \% \\
\text { of partners (15 wives and } \\
10 \text { husbands), } 9,1 \% \text { of } \\
\text { children, } 3 \% \text { of siblings, }\end{array}$ & $\begin{array}{l}\text { The place } \\
\text { of family in } \\
\text { treatment } \\
\text { decision is: } \\
\text { A main } \\
\text { objective of } \\
\text { the study }\end{array}$ & $\begin{array}{l}\text { Semi-structured } \\
\text { interviews: } \\
\text { Interview items } \\
\text { available in the article } \\
\text { for oncologists and } \\
\text { patients. } \\
\text { Themes for the } \\
\text { interviews with } \\
\text { oncologists: } \\
\text { - "Attitudes towards } \\
\quad \text { FMs in } \\
\text { consultations" } \\
\text { - "FMs' roles in the } \\
\text { consultations" } \\
\text { - "Family } \\
\text { involvement in } \\
\text { decision-making" } \\
\text {-"Family } \\
\text { involvement in } \\
\text { decision-making } \\
\text { stages" } \\
\text { "Family } \\
\text { involvement in } \\
\text { decision-making } \\
\text { (barriers and } \\
\text { facilitators)" } \\
\text { Themes for the } \\
\text { interviews with }\end{array}$ & $\begin{array}{l}\text { Three major themes regarding the } \\
\text { links between the families and } \\
\text { treatment decision-making: } \\
\text { - "How families are involved in } \\
\text { the decision-making process: } \\
\text { specific behaviors of families } \\
\text { across } 5 \text { decision-making stages" } \\
\text { - "Attitudes regarding family } \\
\text { involvement [...]" } \\
\text { - "Factors influencing family } \\
\text { involvement" } \\
\text { Families were involved in every } \\
\text { stage of the decision-making } \\
\text { process: } \\
\text { - Before the consultation: } \\
\text { Families influenced the patients to } \\
\text { go to a certain center or to see an } \\
\text { oncologist in particular, } \\
\text { - During information exchanges: } \\
\text { Families provided informational } \\
\text { assistance to both the patients and } \\
\text { the clinicians. Information exchange } \\
\text { could continue outside the } \\
\text { consultations (patient-family } \\
\text { member). } \\
\text { - During the deliberation: } \\
\text { Families' roles were to agree and }\end{array}$ \\
\hline
\end{tabular}




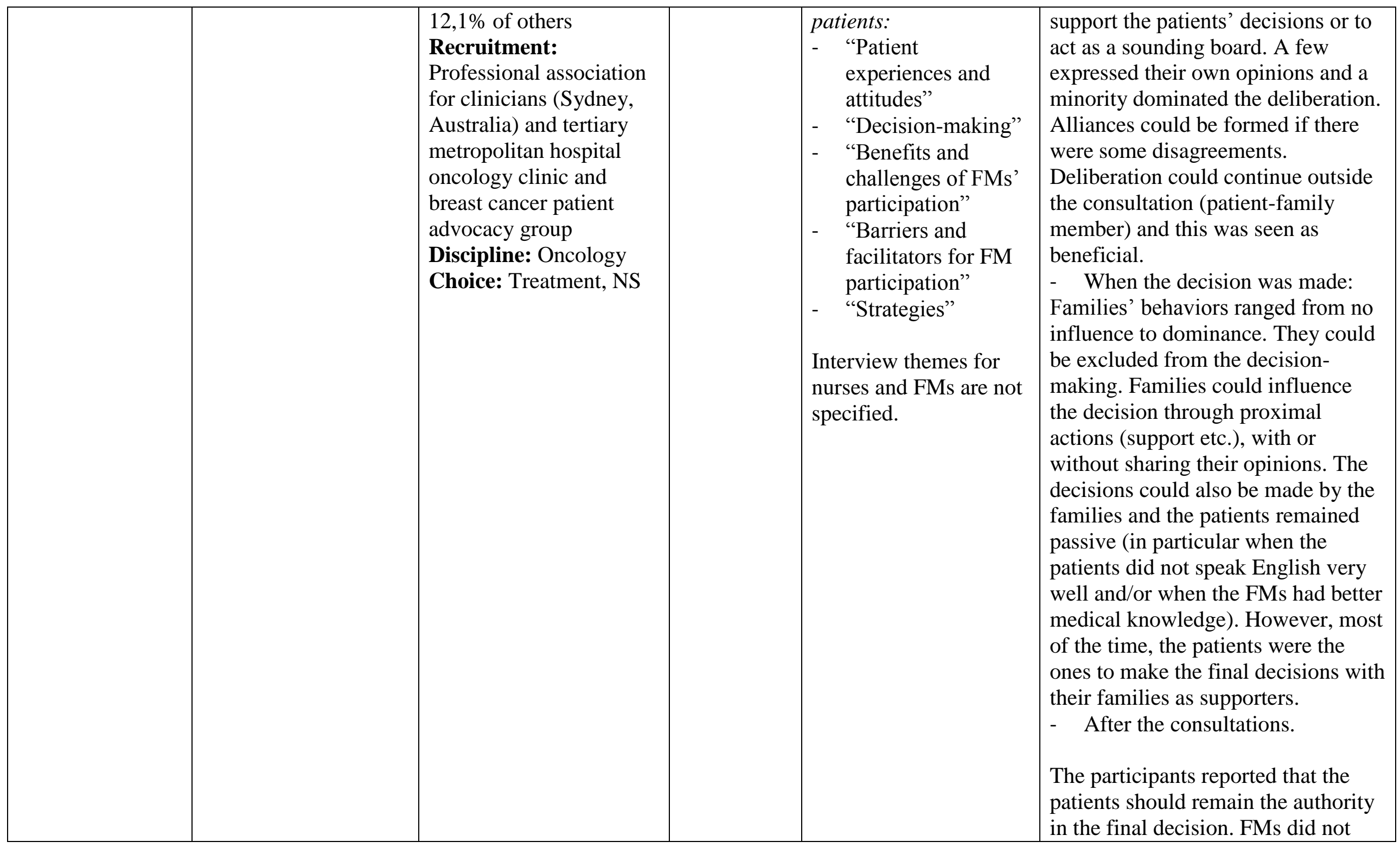




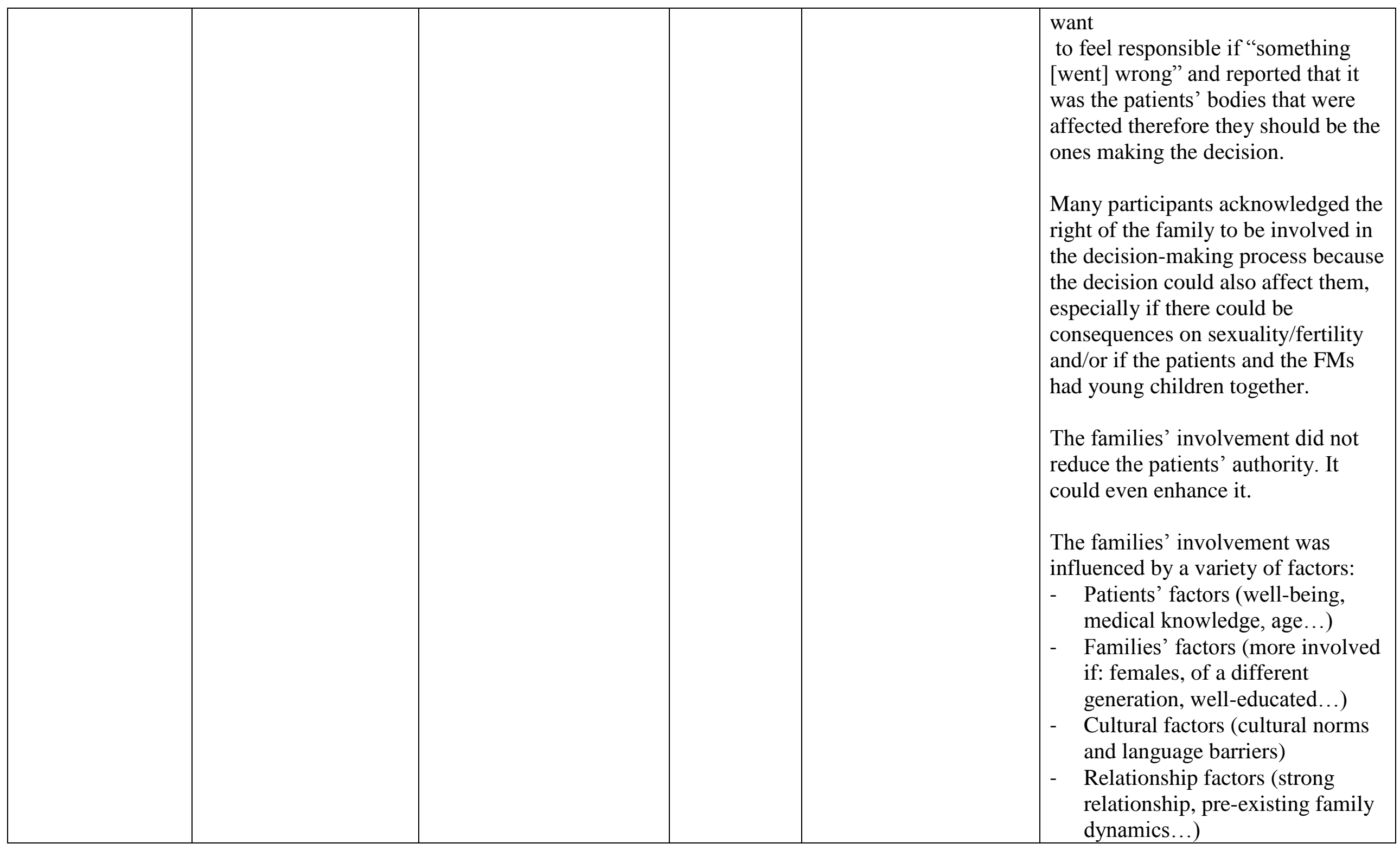




\begin{tabular}{|c|c|c|c|c|c|}
\hline & & & & & $\begin{array}{l}\text { Decision factors (illness } \\
\text { trajectory, level of importance of } \\
\text { the decision, decision affecting } \\
\text { sexuality/fertility or requiring } \\
\text { family assistance) }\end{array}$ \\
\hline $\begin{array}{l}{[39]} \\
\text { Lam et al., } 2013 \\
\text { China }\end{array}$ & $\begin{array}{l}\text { Design: Cross- } \\
\text { sectional study } \\
\text { Method: Mixed }\end{array}$ & $\begin{array}{l}\text { Sample: } 283 \\
\text { consultations (92\% of } \\
\text { patients were } \\
\text { accompanied) } \\
\text { Age: Patients: mean age } \\
\text { = 55.6, SD = } 10.1 \\
\text { Close others: NS } \\
\text { Gender: Patients: all } \\
\text { women } \\
\text { Close others: NS } \\
\text { Close others } \\
\text { characteristics: } 41 \% \text { of } \\
\text { spouses, } 38 \% \text { of adult } \\
\text { children, the rest is NS. } \\
\text { Close others were not } \\
\text { interrogated. } \\
\text { Recruitment: Two } \\
\text { government-funded } \\
\text { breast centers } \\
\text { Discipline: Oncology } \\
\text { Choice: Breast cancer } \\
\text { surgery }\end{array}$ & $\begin{array}{l}\begin{array}{l}\text { The place } \\
\text { of family in } \\
\text { treatment } \\
\text { decision is: } \\
\text { Not a main } \\
\text { objective of } \\
\text { the study }\end{array} \\
\end{array}$ & 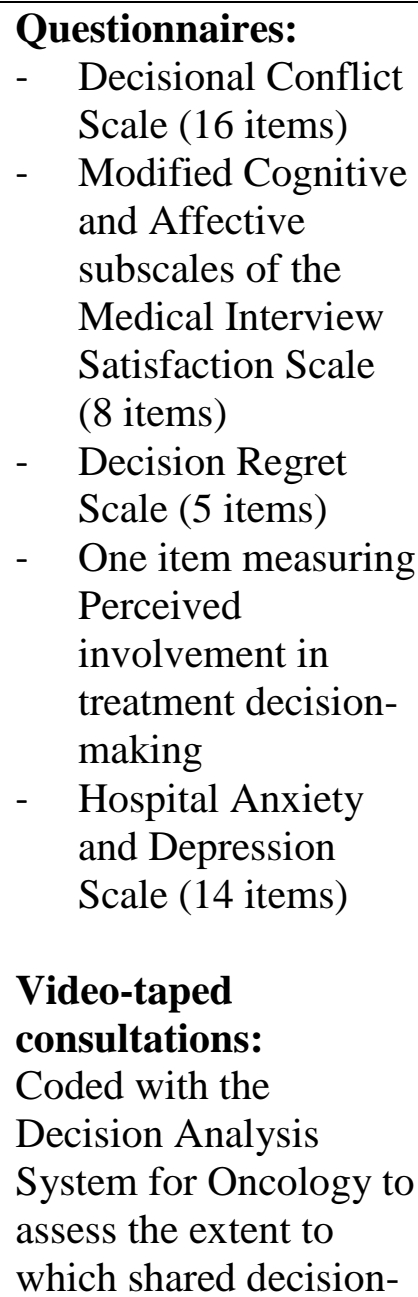 & $\begin{array}{l}\text { The use of shared decision making } \\
\text { correlated with the presence of } \\
\text { companions and the numbers of } \\
\text { questions asked by either the } \\
\text { patients or their companions. } \\
\text { Linear mixed effects analyses } \\
\text { indicated that both subscales of the } \\
\text { Decision Analysis System for } \\
\text { Oncology were significantly related } \\
\text { to fewer questions raised by both } \\
\text { FMs and the patients. }\end{array}$ \\
\hline
\end{tabular}




\begin{tabular}{|c|c|c|c|c|c|}
\hline & & & & $\begin{array}{l}\text { making was adopted in } \\
\text { the consultations. } \\
\text { Non-verbal behaviors } \\
\text { were taken into } \\
\text { account. } \\
\text { Two subscales: } \\
\text { - Establishing a } \\
\text { shared decision- } \\
\text { making framework } \\
\text { (44 items) } \\
\text { - Providing clear and } \\
\text { unbiased } \\
\text { information (19 } \\
\text { items) } \\
\text { Inter-rater reliability (2 } \\
\text { coders) }=.72\end{array}$ & \\
\hline $\begin{array}{l}{[41]} \\
\text { Lin, Pang and } \\
\text { Chen, } 2013 \\
\text { Taiwan }\end{array}$ & $\begin{array}{l}\text { Design: Cross- } \\
\text { sectional and } \\
\text { retrospective study } \\
\text { Method: Qualitative }\end{array}$ & $\begin{array}{l}\text { Sample: } 10 \text { patients } \\
\text { Age: mean age }=43.1 \text {, } \\
\text { ranging from } 20 \text { to } 84 \\
\text { Gender: } 7 \text { women and } 3 \\
\text { men } \\
\text { Close others } \\
\text { characteristics: No } \\
\text { close others included in } \\
\text { the study. However, } \\
\text { participants had to } \\
\text { identify FMs involved in } \\
\text { the decision-making } \\
\text { process (Mostly parents, } \\
\text { partners and/or adult } \\
\text { children). } \\
\text { Recruitment: Medical }\end{array}$ & $\begin{array}{l}\text { The place } \\
\text { of family in } \\
\text { treatment } \\
\text { decision is: } \\
\text { A main } \\
\text { objective of } \\
\text { the study }\end{array}$ & $\begin{array}{l}\text { Semi-structured } \\
\text { interviews: } \\
\text { Three main questions: } \\
\text { - "Please describe the } \\
\text { circumstances when } \\
\text { you made your } \\
\text { surgery decision" } \\
\text { - "How did your } \\
\text { family participate in } \\
\text { your surgery } \\
\text { decision-making } \\
\text { process?" } \\
\text { "Which FMs } \\
\text { participated in your } \\
\text { surgery decision- } \\
\text { making process?" }\end{array}$ & $\begin{array}{l}\text { Three main themes emerged: } \\
\text { - Primacy of family well-being } \\
\text { The patients made their own } \\
\text { decisions but considered their family } \\
\text { needs and potential reactions, as } \\
\text { well as their own responsibilities to } \\
\text { their families } \\
\text { - Families as information brokers } \\
\text { The families were intermediaries } \\
\text { between the physicians and the } \\
\text { patients. The FMs relayed the } \\
\text { information given by the doctors to } \\
\text { the patients and facilitated } \\
\text { communication. They asked } \\
\text { questions and expressed the patients' } \\
\text { concerns. They could receive more }\end{array}$ \\
\hline
\end{tabular}




\begin{tabular}{|c|c|c|c|c|c|}
\hline & & $\begin{array}{l}\text { Center in southern } \\
\text { Taiwan } \\
\text { Discipline: NS } \\
\text { Choice: Non- } \\
\text { oncological elective } \\
\text { surgery }\end{array}$ & & & $\begin{array}{l}\text { information than the patients so they } \\
\text { relayed these. This was seen as } \\
\text { positive by the patients because it } \\
\text { alleviated their burden. } \\
\text { - Families as patient advocates } \\
\text { The FMs defended the patients' } \\
\text { interests, clarified the doubts about } \\
\text { the risks and complications of the } \\
\text { surgery. }\end{array}$ \\
\hline $\begin{array}{l}{[42]} \\
\text { Lin, Hunagand } \\
\text { and Chen, } 2016 \\
\text { Taiwan }\end{array}$ & $\begin{array}{l}\text { Design: Retrospective } \\
\text { study } \\
\text { Method: Qualitative }\end{array}$ & $\begin{array}{l}\text { Sample: } 12 \text { close others } \\
\text { Age: mean age }=47.75 \text {, } \\
\text { ranging from } 23 \text { to } 71 \\
\text { Gender: } 8 \text { men and } 4 \\
\text { women } \\
\text { Close others } \\
\text { characteristics: } 6 \\
\text { partners, } 4 \text { adult } \\
\text { children, } 1 \text { aunt and } 1 \\
\text { ex-wife } \\
\text { Recruitment: Medical } \\
\text { Center in southern } \\
\text { Taiwan } \\
\text { Discipline: Oncology } \\
\text { patients (n=10) and } \\
\text { gastroenterology (n=2) } \\
\text { Choice: Elective surgery }\end{array}$ & $\begin{array}{l}\text { The place } \\
\text { of family in } \\
\text { treatment } \\
\text { decision is: } \\
\text { A main } \\
\text { objective of } \\
\text { the study }\end{array}$ & $\begin{array}{l}\text { In-depth interviews: } \\
\text { Three main domains } \\
\text { explored: } \\
\text { - Discovery of the } \\
\text { illness } \\
\text { - Consequent } \\
\text { processes of } \\
\text { seeking medical } \\
\text { treatments } \\
\text { - FMs involvement }\end{array}$ & $\begin{array}{l}\text { Three main themes emerged: } \\
\text { - "To share responsibility" } \\
\text { The FMs persuaded, encouraged or } \\
\text { expressed their desire for the } \\
\text { patients to accept surgery; FMs } \\
\text { provided emotional support and felt } \\
\text { obligated to partake in the decision- } \\
\text { making process. } \\
\text { - "To ensure the correctness of } \\
\text { medical information" } \\
\text { FMs collected disease-related } \\
\text { information (e.g., among friends or } \\
\text { relatives to better cope with the } \\
\text { disease) and helped the patients to } \\
\text { communicate with the medical staff } \\
\text { (e.g., when the patients were } \\
\text { emotionally troubled, or to fill in the } \\
\text { missing points). } \\
\text { - "To safeguard the patients' well- } \\
\text { being" } \\
\text { FMs protected the patients' rights } \\
\text { and moderated the doctor-patient } \\
\text { relationships (e.g., rephrase some }\end{array}$ \\
\hline
\end{tabular}




\begin{tabular}{|c|c|c|c|c|c|}
\hline & & & & & $\begin{array}{l}\text { words said by the patients to avoid } \\
\text { tensions,). }\end{array}$ \\
\hline $\begin{array}{l}{[43]} \\
\text { Lowden et al., } \\
2014 \\
\text { Canada }\end{array}$ & $\begin{array}{l}\text { Design: Cross- } \\
\text { sectional study } \\
\text { Method: Qualitative }\end{array}$ & $\begin{array}{l}\text { Sample: } 9 \text { patients } \\
\text { Age: mean age }=38.7 \text {, } \\
\text { ranging from } 29 \text { to } 57 \\
\text { Gender: } 7 \text { women and } 2 \\
\text { men } \\
\text { Close others } \\
\text { characteristics: No } \\
\text { close others were } \\
\text { included in this study } \\
\text { Recruitment: } \\
\text { University teaching } \\
\text { hospital in Canada } \\
\text { Discipline: Neurology } \\
\text { (Multiple Sclerosis) } \\
\text { Choice: } \\
\text { Pharmacological } \\
\text { treatment }\end{array}$ & $\begin{array}{l}\text { The place } \\
\text { of family in } \\
\text { treatment } \\
\text { decision is: } \\
\text { Not a main } \\
\text { objective of } \\
\text { the study }\end{array}$ & $\begin{array}{l}\text { Semi-structured } \\
\text { interviews: } \\
\text { Phenomenological } \\
\text { approach. Open-ended } \\
\text { questions. } \\
\text { Interviews began with a } \\
\text { broad question to } \\
\text { encourage the } \\
\text { participants to talk } \\
\text { about their experience } \\
\text { with decision-making. } \\
\text { Further questions } \\
\text { aimed to encourage the } \\
\text { participants to expand } \\
\text { on the subject. } \\
\text { Three patients were } \\
\text { then asked to confirm } \\
\text { the development of the } \\
\text { themes by the } \\
\text { researcher during the } \\
\text { analysis stage of the } \\
\text { study. }\end{array}$ & $\begin{array}{l}\text { FMs could support, encourage and } \\
\text { filter some information about the } \\
\text { illness and its treatments when the } \\
\text { patients were coping with the illness. } \\
\text { The participants described the } \\
\text { decision-making process as team } \\
\text { work with their close others, } \\
\text { although the final decision remained } \\
\text { personal. } \\
\text { When the patients' decision-making } \\
\text { style was incongruent with the } \\
\text { FMs', the latter were excluded from } \\
\text { the discussions. }\end{array}$ \\
\hline $\begin{array}{l}{[44]} \\
\text { Pardon et al., } \\
2012 \\
\text { Belgium }\end{array}$ & $\begin{array}{l}\text { Design: Longitudinal } \\
\text { study } \\
\text { Method: Quantitative }\end{array}$ & $\begin{array}{l}\text { Sample: } 85 \text { patients } \\
\text { Age: Mean age }=64.1 \text {, } \\
\text { SD }=9,7 \\
\text { Gender: } 86 \% \text { are men } \\
\text { Close others } \\
\text { characteristics: No } \\
\text { close others were } \\
\text { included in this study }\end{array}$ & $\begin{array}{l}\text { The place } \\
\text { of family in } \\
\text { treatment } \\
\text { decision is: } \\
\text { Not a main } \\
\text { objective of } \\
\text { the study }\end{array}$ & $\begin{array}{l}\text { Structured } \\
\text { interviews: } \\
\text { Two main domains } \\
\text { explored: } \\
-\quad \text { Preference for } \\
\quad \text { involvement in } \\
\quad \text { ELDs } \\
-\quad \text { Preference for }\end{array}$ & $\begin{array}{l}\text { A clear majority of patients wanted } \\
\text { to involve their families in the } \\
\text { decision in case of incompetence but } \\
\text { only half }(43 \%) \text { had their wishes } \\
\text { met. }\end{array}$ \\
\hline
\end{tabular}




\begin{tabular}{|c|c|c|c|c|c|}
\hline & & $\begin{array}{l}\text { Recruitment: } 3 \\
\text { University hospitals and } \\
\text { General hospitals in } \\
\text { Flanders, Belgium } \\
\text { Discipline: Oncology } \\
\text { (Lung Cancer) } \\
\text { Choice: End-of-Life } \\
\text { decision-making }\end{array}$ & & $\begin{array}{l}\text { involvement of } \\
\text { people other than } \\
\text { the treating } \\
\text { physicians in } \\
\text { medical decision } \\
\text { making in case of } \\
\text { future } \\
\text { incompetence } \\
\text { After-Death } \\
\text { Questionnaire: } \\
\text { It assessed whether the } \\
\text { patients had died } \\
\text { suddenly and } \\
\text { unexpectedly, and if } \\
\text { not, whether ELDs } \\
\text { were made, and if so, } \\
\text { which ones. } \\
\text { Measured the actual } \\
\text { involvement of } \\
\text { competent patients and } \\
\text { other people in these } \\
\text { decisions. } \\
\text { Measure by physicians } \\
\text { of quality of life the } \\
\text { week before death } \\
\text { (EORTC-QLQ-PC) }\end{array}$ & \\
\hline $\begin{array}{l}\text { [45] } \\
\text { Rini et al., } 2011 \\
\text { US }\end{array}$ & $\begin{array}{l}\text { Design: Cross- } \\
\text { sectional and } \\
\text { retrospective study } \\
\text { Method: Quantitative }\end{array}$ & $\begin{array}{l}\text { Sample: } 91 \text { patients } \\
\text { Age: Mean age }=47.9, \\
\text { SD }=14 \\
\text { Gender: } 56 \% \text { are }\end{array}$ & $\begin{array}{l}\text { The place } \\
\text { of family in } \\
\text { treatment } \\
\text { decision is: }\end{array}$ & $\begin{array}{l}\text { Questionnaires: } \\
\text { - } \quad \text { Decisional Conflict } \\
\quad \text { Scale (18 items) } \\
\text { - } \quad \text { Close others' }\end{array}$ & $\begin{array}{l}\text { Different types of influence: } \\
\text { negative/positive and direct/indirect. } \\
\text { A persuasive influence was }\end{array}$ \\
\hline
\end{tabular}




\begin{tabular}{|c|c|c|c|c|c|}
\hline & & $\begin{array}{l}\text { women } \\
\text { Close others } \\
\text { characteristics: No } \\
\text { close others were } \\
\text { included in this study but } \\
\text { patients were asked to } \\
\text { complete information } \\
\text { about their close others. } \\
73 \% \text { were partners and } \\
27 \% \text { "other relations" } \\
\text { Recruitment: } \\
\text { Advertisements, patient } \\
\text { groups or physicians at } \\
\text { an urban hospital in the } \\
\text { northeastern United } \\
\text { States } \\
\text { Discipline: } \\
\text { Inflammatory bowel } \\
\text { disease } \\
\text { Choice: Surgery } \\
\text { (colectomy) }\end{array}$ & $\begin{array}{l}\text { A main } \\
\text { objective of } \\
\text { the study }\end{array}$ & 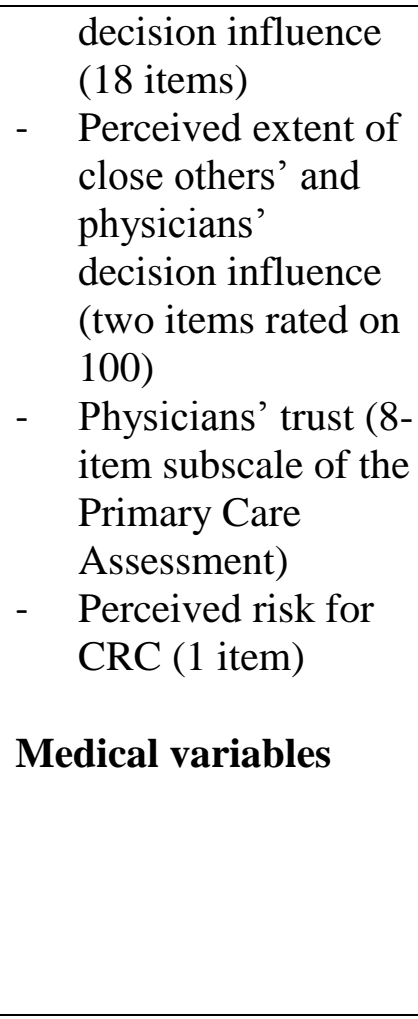 & $\begin{array}{l}\text { associated with a greater probability } \\
\text { for the patients to choose surgery. } \\
\text { Other types of negative influences } \\
\text { were associated with a lower } \\
\text { probability to choose surgery. } \\
\text { Negative influence was associated } \\
\text { with greater decisional conflict } \\
\text { whereas assistance with } \\
\text { understanding was associated with a } \\
\text { lower decisional conflict. However, } \\
\text { assistance with understanding was } \\
\text { associated with decisional conflict in } \\
\text { men and not in women. } \\
\text { Decisional conflict was associated } \\
\text { with having a female close other. }\end{array}$ \\
\hline $\begin{array}{l}\text { [46] } \\
\text { Salter et al., } 2014 \\
\text { USA }\end{array}$ & $\begin{array}{l}\text { Design: Cross- } \\
\text { sectional and } \\
\text { retrospective study } \\
\text { Method: Quantitative }\end{array}$ & $\begin{array}{l}\text { Sample: } 416 \text { patients } \\
\text { Age: } \text { mean age }=56.2 \\
(26.4 \% \text { were }>65) \\
\text { Gender: } 46,2 \% \text { are } \\
\text { women } \\
\text { Close others } \\
\text { characteristics: No } \\
\text { close others were } \\
\text { included in this study } \\
\text { Recruitment: } 26 \text { free- } \\
\text { standing dialysis centers }\end{array}$ & $\begin{array}{l}\text { The place } \\
\text { of family in } \\
\text { treatment } \\
\text { decision is: } \\
\text { Not a main } \\
\text { objective of } \\
\text { the study }\end{array}$ & $\begin{array}{l}\text { Questionnaire: } \\
\text { Discussion about } \\
\text { kidney transplantation. } \\
\text { "Have any of the } \\
\text { following people } \\
\text { discussed kidney } \\
\text { transplantation with } \\
\text { you: } \\
\text { - Nephrologist } \\
\text { - Primary medical } \\
\quad \text { doctor }\end{array}$ & $\begin{array}{l}\text { Older participants talked less about } \\
\text { kidney transplantation with their } \\
\text { partners and families than younger } \\
\text { patients. } \\
\text { They also reported fewer } \\
\text { encouragements from their families, } \\
\text { especially women. }\end{array}$ \\
\hline
\end{tabular}




\begin{tabular}{|c|c|c|c|c|c|}
\hline & & $\begin{array}{l}\text { in Baltimore and } 6 \\
\text { surrounding counties in } \\
\text { Maryland. They were } \\
\text { enrolled in another } \\
\text { study. } \\
\text { Discipline: Nephrology } \\
\text { (CKD) } \\
\text { Choice: Transplantation }\end{array}$ & & $\begin{array}{ll}\text { - } & \text { Dialysis staff } \\
- & \text { Significant other } \\
\text { - } & \text { Family member } \\
\text { - } & \text { Friend" } \\
\text { Rating for the } \\
\text { discussions }\end{array}$ & \\
\hline $\begin{array}{l}\text { [47] } \\
\text { Shaw et al., } 2015 \\
\text { Australia }\end{array}$ & $\begin{array}{l}\text { Design: Cross- } \\
\text { sectional and } \\
\text { retrospective study } \\
\text { Method: Qualitative }\end{array}$ & $\begin{array}{l}\text { Sample: } 91 \text { participants } \\
\text { ( } 73 \text { patients and } 18 \\
\text { caregivers) } \\
\text { Age: Participants: <40 } \\
\text { years }=7 \% ; 40-49 \\
\text { years }=20 \% ; 50-59 \text { years } \\
=29 \% ; 60-69 \text { years = } \\
29 \% ;>70 \text { years = } 15 \% \\
\text { Gender: Participants: } \\
70 \% \text { are women } \\
\text { Close others } \\
\text { characteristics: NS } \\
\text { Recruitment: } \\
\text { Community-based } \\
\text { cancer support groups } \\
\text { and } 3 \text { oncology } \\
\text { outpatient clinics in } \\
\text { Sydney } \\
\text { Discipline: Oncology } \\
\text { (Cancer NS) } \\
\text { Choice: Treatment NS }\end{array}$ & $\begin{array}{l}\text { The place } \\
\text { of family in } \\
\text { treatment } \\
\text { decision is: } \\
\text { A main } \\
\text { objective } \\
\text { study }\end{array}$ & $\begin{array}{l}\text { Focus groups or semi- } \\
\text { structured interviews: } \\
\text { Chosen by the patients. } \\
\text { The participants' } \\
\text { experiences and } \\
\text { preferences for } \\
\text { treatment decision- } \\
\text { making. } \\
\text { Open-ended questions } \\
\text { and probes. } \\
\text { Thematic analysis: } \\
\text { Based on a grounded } \\
\text { theory. } 6 \text { randomly } \\
\text { selected transcripts } \\
\text { were analyzed. }\end{array}$ & $\begin{array}{l}\text { Four main themes: } \\
\text { - Perceived role of the patients in } \\
\text { decision-making } \\
\text { Most participants reported a passive } \\
\text { involvement in decision-making } \\
\text { discussions (doctors did not seek } \\
\text { their opinions or the patients did not } \\
\text { want to be involved). The doctors } \\
\text { were perceived as the experts. } \\
\text { - Access to information and the } \\
\quad \text { impact of language } \\
\text { Most participants reported that their } \\
\text { doctors gave less information than } \\
\text { they would have liked. Access to } \\
\text { information was an important factor } \\
\text { influencing the patients' role during } \\
\text { the decision-making process. For } \\
\text { some patients though, too much } \\
\text { information could be distressing. } \\
\text { Language was a huge barrier to } \\
\text { information (FMs could act as } \\
\text { translators, but struggled to translate } \\
\text { medical terminology). } \\
\text { - Cultural influences }\end{array}$ \\
\hline
\end{tabular}




\begin{tabular}{|c|c|c|c|c|c|}
\hline & & & & & $\begin{array}{l}\text { - Family involvement } \\
\text { Some participants discussed their } \\
\text { treatment options with their families } \\
\text { and others did not involve their } \\
\text { families at all. Arabic patients often } \\
\text { thought that families should make } \\
\text { the decision to relieve the patients } \\
\text { from the burden of having to weigh } \\
\text { up options. If the patients who held } \\
\text { this view were forced to make a } \\
\text { decision by themselves, feelings of } \\
\text { distress ensued. }\end{array}$ \\
\hline $\begin{array}{l}\text { [48] } \\
\text { Shelton et al., } \\
2013 \\
\text { USA }\end{array}$ & $\begin{array}{l}\text { Design: Longitudinal } \\
\text { study (preliminary } \\
\text { results) } \\
\text { Method: Quantitative }\end{array}$ & $\begin{array}{l}\text { Sample: } 1479 \text { patients } \\
\text { Age: } 47 \% \text { of patients } \\
\text { were between } 50 \text { and } 64 \\
\text { years old } \\
\text { Gender: all women } \\
\text { Close others } \\
\text { characteristics: No } \\
\text { close others were } \\
\text { included in this study } \\
\text { Recruitment: Multisite } \\
\text { cohort study: Columbia } \\
\text { University Medical } \\
\text { Center, Mount Sinai } \\
\text { School of Medicine, } \\
\text { Kaiser-Permanente of } \\
\text { Northern California and } \\
\text { Henry Ford Health } \\
\text { System } \\
\text { Discipline: Oncology } \\
\text { (Breast cancer) }\end{array}$ & $\begin{array}{l}\text { The place } \\
\text { of family in } \\
\text { treatment } \\
\text { decision is: } \\
\text { Not a main } \\
\text { objective of } \\
\text { the study }\end{array}$ & $\begin{array}{l}\text { Questionnaire: } \\
\text { - } \quad \text { Treatment-decision } \\
\text { process and } \\
\text { considerations } \\
\text { (questions about: } \\
\text { referral to a medical } \\
\text { oncologist, current } \\
\text { care, treatments, } \\
\text { decision-making and if } \\
\text { close others where } \\
\text { present during } \\
\text { consultations) } \\
\text { - Treatment } \\
\text { considerations (15 } \\
\text { items for } \\
\text { chemotherapy and } \\
\text { 13 items for } \\
\text { hormonal therapy) } \\
\text { - Attitude toward } \\
\text { treatments }\end{array}$ & $\begin{array}{l}\text { Most patients ( } 76 \%) \text { were } \\
\text { accompanied by a FM. } 54 \% \text { of them } \\
\text { helped the patient in her choice. } \\
\text { Older women (> } 65 \text { years old) were } \\
\text { more likely to be helped in their } \\
\text { decision-making process. } \\
\text { Depending in the culture, the } \\
\text { characteristics of the FMs who } \\
\text { helped the patients were different. } \\
\text { Asian women were helped by their } \\
\text { partners whereas Hispanic women } \\
\text { were helped by their parents, } \\
\text { children or grand-children. }\end{array}$ \\
\hline
\end{tabular}




\begin{tabular}{|c|c|c|c|c|c|}
\hline & & $\begin{array}{l}\text { Choice: Chemotherapy, } \\
\text { hormonal therapy }\end{array}$ & & $\begin{array}{l}\text { measured with: } \\
\text { Psychosocial factors } \\
\text { (14 items), fatalistic } \\
\text { beliefs subscale of the } \\
\text { Mental Adjustment to } \\
\text { Cancer Scale (18 items) } \\
\text { and social support } \\
\text { subscale of the Medical } \\
\text { Outcome Study (19 } \\
\text { items). } \\
\text { - Provider-related } \\
\quad \text { factors and } \\
\quad \text { communication: } \\
\text { Assessment of patients' } \\
\text { preferred roles and } \\
\text { involvement in the } \\
\text { decision-making, } \\
\text { Provider } \\
\text { communication was } \\
\text { also measured (4 items) } \\
\text { and the group-based } \\
\text { medical Mistrust Scale } \\
\text { was used to evaluate } \\
\text { medical mistrust. }\end{array}$ & \\
\hline $\begin{array}{l}\text { [49] } \\
\text { Uldry et al., } 2013 \\
\text { Switzerland }\end{array}$ & $\begin{array}{l}\text { Design: Cross- } \\
\text { sectional and } \\
\text { longitudinal study } \\
\text { Method: Quantitative }\end{array}$ & $\begin{array}{l}\text { Sample: } 253 \text { patients } \\
\text { Age: Mean age }=58.3, \\
\text { SD }=15.5 \\
\text { Gender: } 52.6 \% \text { are men } \\
\text { Close others } \\
\text { characteristics: No } \\
\text { close others were } \\
\text { included in this study }\end{array}$ & $\begin{array}{l}\text { The place } \\
\text { of family in } \\
\text { treatment } \\
\text { decision is: } \\
\text { Not a main } \\
\text { objective of } \\
\text { the study }\end{array}$ & $\begin{array}{l}\text { Questionnaire: } \\
13 \text { binary questions } \\
\text { (Yes/No) measuring: } \\
\text { - the patients' } \\
\text { requirement for } \\
\text { type and extent of } \\
\text { information } \\
\text { - the patients' wish to }\end{array}$ & $\begin{array}{l}38.3 \% \text { of patients wanted their } \\
\text { families to be involved in the } \\
\text { decision-making process for a } \\
\text { second surgery and/or further ICU } \\
\text { stay. } \\
\text { For women, their families' opinion } \\
\text { was very important even if they } \\
\text { were conscious ( } p=0.052) \text {. }\end{array}$ \\
\hline
\end{tabular}




\begin{tabular}{|c|c|c|c|c|c|}
\hline & & $\begin{array}{l}\text { Recruitment: } \\
\text { Department of Visceral } \\
\text { Surgery, University } \\
\text { Hospital of Lausanne } \\
\text { Discipline: Visceral } \\
\text { Surgery } \\
\text { Choice: Serious } \\
\text { postoperative } \\
\text { complications }\end{array}$ & & $\begin{array}{l}\text { be involved (or not) } \\
\text { in the decision- } \\
\text { making process. } \\
\text { - the patients' wish to } \\
\text { see their families } \\
\text { involved in } \\
\text { decision-making (or } \\
\text { not) }\end{array}$ & $\begin{array}{l}\text { If the patients were conscious, only } \\
29 \% \text { of them wanted to include their } \\
\text { families in the resuscitation } \\
\text { decision-making. This percentage } \\
\text { rose to } 57.4 \text { if the patients were } \\
\text { unconscious. } \\
\text { Men's desire to include their } \\
\text { families in the decision-making was } \\
\text { lower than women's. A similar } \\
\text { result could be observed in old vs } \\
\text { young people. }\end{array}$ \\
\hline $\begin{array}{l}{[50]} \\
\text { Boehmer and } \\
\text { Clarck, 2001 } \\
\text { USA }\end{array}$ & $\begin{array}{l}\text { Design: Retrospective } \\
\text { and cross-sectional } \\
\text { study } \\
\text { Methods: NS }\end{array}$ & $\begin{array}{l}\text { Sample: 14 participants } \\
\text { (7 patients and } 7 \\
\text { partners) } \\
\text { Age: Patients: ranging } \\
\text { from } 61 \text { to } 75 \\
\text { Partners: NS } \\
\text { Gender: Patients: All } \\
\text { men } \\
\text { Close others: All women } \\
\text { Close others } \\
\text { characteristics: } \\
\text { Significant other, } \\
\text { married, all women } \\
\text { Recruitment: NS } \\
\text { Discipline: Prostate } \\
\text { cancer } \\
\text { Choice: Prostate cancer } \\
\text { treatment: Injection of } \\
\text { Lupron vs. Orchiectomy }\end{array}$ & 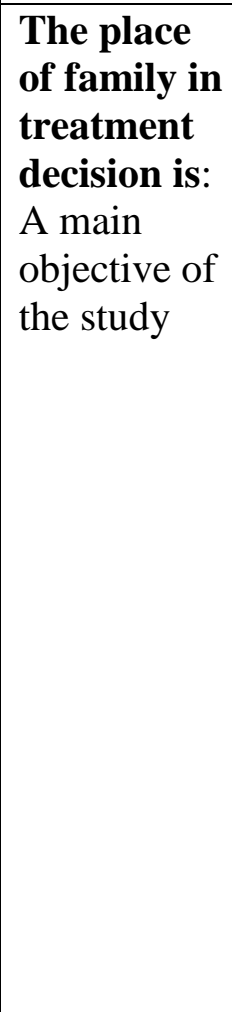 & $\begin{array}{l}\text { Focus groups: } \\
\text { From a larger study } \\
\text { with } 15 \text { focus groups of } \\
\text { men and } 2 \text { of some of } \\
\text { their wives. Used } 7 \\
\text { couples for which they } \\
\text { had both the patients } \\
\text { and their wives' data. } \\
\text { Always started with the } \\
\text { description of their } \\
\text { experiences with } \\
\text { prostate cancer. }\end{array}$ & $\begin{array}{l}\text { Three types of decision-making } \\
\text { process depending on the coalitions } \\
\text { between the three actors (the } \\
\text { physicians, the patients, and their } \\
\text { wives). } \\
\text { - Doctor-Patient alliance } \\
\text { (exclusion of the spouses from } \\
\text { the decision-making process): } \\
\text { Doctors' opinions were very } \\
\text { important to the patients. No } \\
\text { treatment discussion between the } \\
\text { patients and their wives. The wives } \\
\text { seemed to have no role in the } \\
\text { decision-making. } \\
\text { - Wives' participation in the } \\
\text { decision-making process } \\
\text { initiated by the physicians: } \\
\text { Reasons: communication with the } \\
\text { patients was difficult or they were } \\
\text { judged too frail by the doctors. } \\
\text { - The main coalition was between }\end{array}$ \\
\hline
\end{tabular}




\begin{tabular}{|c|c|c|c|c|c|}
\hline & & & & & $\begin{array}{l}\text { the patients and their wives: } \\
\text { They and/or the families had very } \\
\text { active roles on the patients' } \\
\text { demands. They encouraged the } \\
\text { patients to get more involved in the } \\
\text { decision-making process and can } \\
\text { discuss the choices offered by the } \\
\text { clinicians. The wives represented a } \\
\text { support in the decision-making and } \\
\text { could inquire about the treatment } \\
\text { options. }\end{array}$ \\
\hline $\begin{array}{l}52] \\
\text { Degner and } \\
\text { Sloan, } 1992 \\
\text { Canada }\end{array}$ & $\begin{array}{l}\text { Design: Longitudinal } \\
\text { study } \\
\text { Method: Quantitative }\end{array}$ & $\begin{array}{l}\text { Sample: } 436 \text { cancer } \\
\text { patients and } 482 \\
\text { members of the general } \\
\text { public participated } \\
\text { Age: Cancer patients: } \\
\text { mean= 59, SD= } 13.9 \\
\text { Householders: mean= } \\
\text { 42, SD= } 16.4 \\
\text { Gender: Cancer } \\
\text { patients: } 52 \% \text { are men } \\
\text { Householders: } 45 \% \text { are } \\
\text { men } \\
\text { Close others } \\
\text { characteristics: No } \\
\text { close others were } \\
\text { included in this study } \\
\text { Recruitment: Two } \\
\text { tertiary referral clinics } \\
\text { for cancer patients in } \\
\text { Manitoba, Canada and } \\
\text { Winnipeg area study }\end{array}$ & $\begin{array}{l}\text { The place } \\
\text { of family in } \\
\text { treatment } \\
\text { decision is: } \\
\text { Not a main } \\
\text { objective of } \\
\text { the study }\end{array}$ & $\begin{array}{l}\text { Questionnaires: } \\
\text { We will only report the } \\
\text { content of the survey of } \\
\text { cancer patients. } \\
\text { - Demographic and } \\
\text { disease/treatment } \\
\text { information } \\
\text { - A measure of } \\
\text { consumer } \\
\text { preferences about } \\
\text { roles in treatment } \\
\text { decision-making } \\
\text { The Symptom } \\
\text { distress scale (13 } \\
\text { items) }\end{array}$ & $\begin{array}{l}59 \% \text { of newly diagnosed patients } \\
\text { wanted the physicians to make the } \\
\text { treatment decisions on their behalf. } \\
\text { The most reported first choice of } \\
\text { patients was the following } \\
\text { statement: "I prefer that my doctor } \\
\text { makes the final decision about } \\
\text { which treatment will be used, but } \\
\text { seriously considers my opinion". } \\
\text { If they were to become too ill to } \\
\text { participate, only } 10 \% \text { wanted the } \\
\text { family to dominate the decision- } \\
\text { making process. } \\
\text { In such cases, most patients wanted } \\
\text { the physicians and families to } \\
\text { collaborate. } \\
\text { Women, especially women with } \\
\text { cancers of the reproductive system, } \\
\text { as well as younger cancer patients } \\
\text { preferred more family involvement }\end{array}$ \\
\hline
\end{tabular}




\begin{tabular}{|c|c|c|c|c|c|}
\hline & & $\begin{array}{l}\text { (systematic random } \\
\text { sample of households) } \\
\text { Discipline: Oncology } \\
\text { (Diverse cancers) } \\
\text { Choice: Cancer } \\
\text { treatments }\end{array}$ & & & $\begin{array}{l}\text { in decision-making if they were too } \\
\text { ill to participate. }\end{array}$ \\
\hline $\begin{array}{l}53] \\
\text { Elit et al., } 2002 \\
\text { Canada }\end{array}$ & $\begin{array}{l}\text { Design: Retrospective } \\
\text { and cross-sectional } \\
\text { study } \\
\text { Method: Qualitative }\end{array}$ & $\begin{array}{l}\text { Sample: } 21 \text { patients who } \\
\text { had undergone surgery } \\
\text { Age: mean age }=60.6, \\
\text { ranging from } 47 \text { to } 77 \\
\text { Gender: All women } \\
\text { Close others } \\
\text { characteristics: No } \\
\text { close others included in } \\
\text { the study } \\
\text { Recruitment: Two } \\
\text { cancer centers in Ontario } \\
\text { Discipline: Ovarian } \\
\text { Cancer } \\
\text { Choice: Chemotherapy }\end{array}$ & \begin{tabular}{|l}
$\begin{array}{l}\text { The place } \\
\text { of family in } \\
\text { treatment } \\
\text { decision is: }\end{array}$ \\
$\begin{array}{l}\text { Not a main } \\
\text { objective of } \\
\text { the study }\end{array}$
\end{tabular} & $\begin{array}{l}\text { Semi-structured } \\
\text { interviews } \\
\text { Themes explored: } \\
\text { patients' information } \\
\text { needs and knowledge } \\
\text { about treatment options } \\
\text { and their risks and } \\
\text { benefits, patient } \\
\text { perceptions of choice } \\
\text { about the best treatment } \\
\text { to implement, who was } \\
\text { involved in the } \\
\text { treatment decision- } \\
\text { making process, the } \\
\text { patients' desires vs. } \\
\text { actual role in decision } \\
\text { making and her } \\
\text { perceived relationship } \\
\text { with her physician(s) }\end{array}$ & $\begin{array}{l}\text { Patients wanted to be involved in } \\
\text { decision-making but reported having } \\
\text { difficulties to focus and felt } \\
\text { pressured to make a decision. } \\
\text { Many of them indicated that being } \\
\text { involved in the decision-making } \\
\text { process included seeking advice and } \\
\text { input from FMs. } \\
\text { Most patients came to the } \\
\text { appointment with their oncologists } \\
\text { with a family member or a friend. } \\
\text { They reported both positive and } \\
\text { negative influences. } \\
\text { - Positive influences: Coming } \\
\text { from their family and friends. } \\
\text { They felt these people spoke for } \\
\text { them and found reassurance } \\
\text { from the input of their friends in } \\
\text { the medical profession. } \\
\text { Negative influences: FMs who } \\
\text { were negative, the changes in } \\
\text { attitude of their social circle (e.g. } \\
\text { Cancer label), family history of } \\
\text { cancer and death despite } \\
\text { treatments hindered some }\end{array}$ \\
\hline
\end{tabular}




\begin{tabular}{|c|c|c|c|c|c|}
\hline & & & & & $\begin{array}{l}\text { women in their decision-making } \\
\text { process. }\end{array}$ \\
\hline $\begin{array}{l}{[54]} \\
\text { Heyland et al., } \\
2006 \\
\text { Canada }\end{array}$ & $\begin{array}{l}\text { Design: Cross- } \\
\text { sectional study } \\
\text { Method: Quantitative }\end{array}$ & $\begin{array}{l}\text { Sample: } 440 \text { patients } \\
\text { and } 176 \text { caregivers } \\
\text { Age: Patients: mean age } \\
=71.2, \text { SD = 9.1 } \\
\text { Caregivers: mean age = } \\
\text { 56.5, SD = } 13.9 \\
\text { Gender: Patients: } 50.3 \% \\
\text { male (but } 2 \% \text { missing) } \\
\text { Caregivers: } 65 \% \text { are } \\
\text { women (but } 1.2 \% \\
\text { missing) } \\
\text { Close others } \\
\text { characteristics: } 47.8 \% \\
\text { of children, } 44.6 \% \text { of } \\
\text { partners; } 3.8 \% \text { of } \\
\text { relatives, } 33.2 \% \text { of } \\
\text { siblings, 1.3\% of NS and } \\
\text { 0.6\% of friends. } \\
\text { Recruitment: } 5 \text { tertiary } \\
\text { acute care teaching } \\
\text { hospitals in Canada } \\
\text { Discipline: End-stage } \\
\text { cancer and advanced } \\
\text { medical diseases } \\
\text { Choice: } \\
\text { Cardiopulmonary } \\
\text { resuscitation (CPR) }\end{array}$ & $\begin{array}{l}\text { The place } \\
\text { of family in } \\
\text { treatment } \\
\text { decision is: } \\
\text { Not a main } \\
\text { objective of } \\
\text { the study }\end{array}$ & $\begin{array}{l}\text { Auto-questionnaire: } \\
\text { Developed and pilot- } \\
\text { tested by the authors. } \\
\text { Questionnaire based on } \\
\text { interviews with patients } \\
\text { and caregivers as well } \\
\text { as conceptual } \\
\text { frameworks related to } \\
\text { quality end of life care. } \\
\text { Two main parts: } \\
\text { - Issues and views of } \\
\text { patients on quality } \\
\text { of end of life care } \\
\text { - CPR } \\
\text { communication and } \\
\text { decision-making }\end{array}$ & $\begin{array}{l}34.3 \% \text { of patients spoke to a } \\
\text { physician regarding CPR whereas } \\
46.4 \% \text { talked about it with a family } \\
\text { member. } \\
\text { Patients and FMs reported two main } \\
\text { informational needs: "knowledge } \\
\text { about the expected course of the } \\
\text { illness" and "knowledge about the } \\
\text { expected quality of life after CPR". } \\
\text { A higher number of FMs rated } \\
\text { informational needs as "extremely } \\
\text { important" as opposed to patients. } \\
34.1 \% \text { of patients preferred a triadic } \\
\text { deliberation whereas } 23.2 \% \text { of } \\
\text { patients wanted to be the only one } \\
\text { involved and } 8.2 \% \text { preferred their } \\
\text { physicians alone to be the main } \\
\text { person making the decision. } \\
\text { Regarding decision-making per se, if } \\
\text { they had to decide now, } 22.5 \% \text { of } \\
\text { the patients wished to make the } \\
\text { decision themselves, } 26.6 \% \text { desired } \\
\text { joint decision making with their } \\
\text { physicians and themselves and } \\
26.8 \% \text { wanted to make the decision } \\
\text { with the physicians' input. There } \\
\text { was no answer option for this }\end{array}$ \\
\hline
\end{tabular}




\begin{tabular}{|c|c|c|c|c|c|}
\hline & & & & & $\begin{array}{l}\text { question regarding the involvement } \\
\text { of their families. }\end{array}$ \\
\hline $\begin{array}{l}{[55]} \\
\text { McSkimming et } \\
\text { al., } 1999 \\
\text { USA }\end{array}$ & $\begin{array}{l}\text { Design: Cross- } \\
\text { sectional and } \\
\text { retrospective study } \\
\text { Method: Qualitative }\end{array}$ & $\begin{array}{l}\text { Sample: } 77 \text { patients, } 70 \\
\text { FMs and } 81 \text { bereaved } \\
\text { participants } \\
\text { Age: Patients: mean age } \\
=53 \text {, ranging from } 20 \text { to } \\
91 \\
\text { FMs: mean age = 54, } \\
\text { ranging from } 20 \text { to } 80 \\
\text { Bereaved participants: } \\
\text { mean age = 52, ranging } \\
\text { from } 20 \text { to } 80 \\
\text { Gender: Patients: } 57 \% \\
\text { are women } \\
\text { FMs: } 76 \% \text { are women } \\
\text { Bereaved participants: } \\
\text { 59\% are women } \\
\text { Close others } \\
\text { characteristics: NS } \\
\text { Recruitment: } 11 \\
\text { Catholic Healthcare } \\
\text { Facilities } \\
\text { Discipline: Life } \\
\text { threatening illnesses } \\
\text { Choice: Treatment, NS }\end{array}$ & $\begin{array}{l}\text { The place } \\
\text { of family in } \\
\text { treatment } \\
\text { decision is: } \\
\text { Not a main } \\
\text { objective of } \\
\text { the study }\end{array}$ & $\begin{array}{l}\text { Focus-groups: } \\
6 \text { open-ended questions } \\
\text { for all the groups: } \\
\text { - } \quad \text { Tell me about your } \\
\text { experience, or the } \\
\text { experiences of } \\
\text { someone you know, } \\
\text { from the time the } \\
\text { illness appeared to } \\
\text { be life-threatening } \\
\text { or fatal. } \\
\text { - How were you } \\
\text { prepared for this? } \\
\text { - What were your } \\
\text { concerns or fears? } \\
\text { - What were the } \\
\text { problems or barriers } \\
\text { you faced; what } \\
\text { helped and what did } \\
\text { not help? } \\
\text { Any experience can } \\
\text { impact our attitudes } \\
\text { and beliefs. How } \\
\text { has your experience } \\
\text { changed your } \\
\text { attitudes or beliefs? } \\
\text { Is there anything } \\
\text { else you would like } \\
\text { us to know? }\end{array}$ & $\begin{array}{l}\text { The patients would like for the } \\
\text { physicians to listen to both them and } \\
\text { their families. They considered they } \\
\text { were a unit and should be considered } \\
\text { as such. } \\
\text { FMs wished to be included in the } \\
\text { discussions with the physicians } \\
\text { because the decision and the } \\
\text { information given during these } \\
\text { exchanges would affect them as } \\
\text { well. } \\
\text { They also wanted their opinions to } \\
\text { be considered and taken seriously. } \\
\text { They would like their "expertise of } \\
\text { the patient" to be recognized by the } \\
\text { doctors. } \\
\text { The illness was perceived as shared. }\end{array}$ \\
\hline
\end{tabular}




\begin{tabular}{|c|c|c|c|c|c|}
\hline $\begin{array}{l}57] \\
\text { Wuerth et al., } \\
2002 \\
\text { USA }\end{array}$ & $\begin{array}{l}\text { Design: Cross- } \\
\text { sectional and } \\
\text { retrospective study } \\
\text { Method: Qualitative }\end{array}$ & $\begin{array}{l}\text { Sample: } 40 \text { patients } \\
\text { Age: Peritoneal dialysis: } \\
\text { mean age = 58, SD = NS } \\
\text { Hemodialysis: mean age } \\
=73 \text {, SD = NS } \\
\text { Gender: Peritoneal } \\
\text { dialysis: } 65 \% \text { are men } \\
\text { Hemodialysis: } 60 \% \text { are } \\
\text { men } \\
\text { Close others } \\
\text { characteristics: No } \\
\text { close others were } \\
\text { included in this study } \\
\text { Recruitment: One } \\
\text { freestanding CPD unit } \\
\text { and two freestanding HD } \\
\text { units in Connecticut } \\
\text { Discipline: Nephrology } \\
\text { (CKD) } \\
\text { Choice: Peritoneal vs. } \\
\text { Hemodialysis }\end{array}$ & $\begin{array}{l}\text { The place } \\
\text { of family in } \\
\text { treatment } \\
\text { decision is: } \\
\text { Not a main } \\
\text { objective of } \\
\text { the study }\end{array}$ & $\begin{array}{l}\text { Structured Interview: } \\
\text { Covering the following } \\
\text { subjects: } \\
\text { - "Did the patient } \\
\text { have a choice of } \\
\text { CPD or HD? } \\
\text { - Did the patient } \\
\text { attend pre-dialysis } \\
\text { program? } \\
\text { - Did the patient's } \\
\text { doctor/medical staff } \\
\text { influence his or her } \\
\text { decision in any } \\
\text { way? } \\
\text { Was the patient } \\
\text { influenced by } \\
\text { information from } \\
\text { sources other than } \\
\text { medical personnel } \\
\text { (FMs etc.)? } \\
\text { What was the } \\
\text { patient's perception } \\
\text { of the advantages } \\
\text { and disadvantages } \\
\text { for each treatment? } \\
\text { How did the patient } \\
\text { think the different } \\
\text { treatment regimens } \\
\text { would impact his or } \\
\text { her lifestyle and } \\
\text { quality of life?" }\end{array}$ & $\begin{array}{l}30 \% \text { of the patients considered that } \\
\text { their partners or a FM were } \\
\text { important in the decision-making } \\
\text { process. Especially for patients in } \\
\text { peritoneal dialysis compared with } \\
\text { patients in hemodialysis. } \\
\text { Hemodialysis patients did not want } \\
\text { to involve their families in the } \\
\text { treatment. }\end{array}$ \\
\hline [58] & Design: Cross- & Sample: 35 patients and & The place & Semi-directive & The patients' informational needs \\
\hline
\end{tabular}




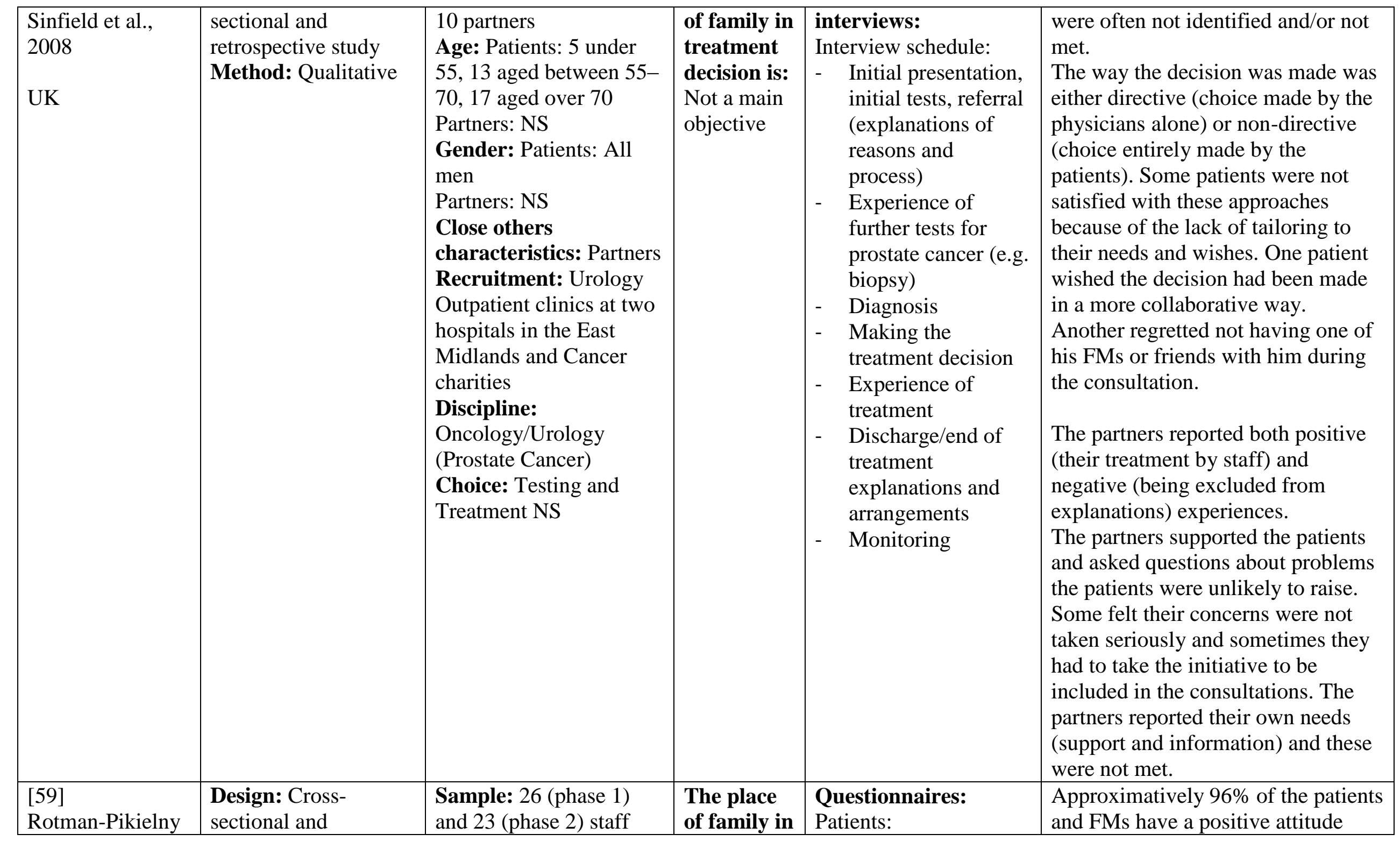




\begin{tabular}{|c|c|c|c|c|c|}
\hline $\begin{array}{l}\text { et al., } 2006 \\
\text { Israel }\end{array}$ & $\begin{array}{l}\text { longitudinal study } \\
\text { Method: Quantitative }\end{array}$ & $\begin{array}{l}\text { members, } 61 \text { patients } \\
\text { and } 72 \text { FMs } \\
\text { Age: NS } \\
\text { Gender: NS } \\
\text { Close others } \\
\text { characteristics: NS } \\
\text { Recruitment: Meir } \\
\text { Medical Center in Kfar- } \\
\text { Saba } \\
\text { Discipline: NS } \\
\text { Choice: NS }\end{array}$ & $\begin{array}{l}\text { treatment } \\
\text { decision is: } \\
\text { Not a main } \\
\text { objective of } \\
\text { the study }\end{array}$ & $\begin{array}{l}\text { - Interest in family } \\
\text { involvement in } \\
\text { ward rounds } \\
\text { - Which FMs they } \\
\text { would involve } \\
\text { - For what benefits } \\
\text { FMs: } \\
\text { - Desire to be } \\
\text { involved in ward } \\
\text { rounds } \\
\text { Degree of } \\
\text { contribution of ward } \\
\text { rounds to their } \\
\text { understanding of } \\
\text { their family } \\
\text { member's disease, } \\
\text { to their involvement } \\
\text { in the decision- } \\
\text { making process and } \\
\text { to reducing their } \\
\text { anxiety } \\
\text { Staff: } \\
\text { Role of the families } \\
\text { in the patients' care } \\
\text { during their } \\
\text { hospitalization } \\
\text { Possible advantages } \\
\text { and disadvantages } \\
\text { of the families } \\
\text { involvement }\end{array}$ & $\begin{array}{l}\text { towards the families being involved } \\
\text { in ward rounds. } \\
\text { The patients and FMs believed that } \\
\text { the presence of FMs would help } \\
\text { them be more involved in decision- } \\
\text { making. } \\
\text { The patients thought that involving } \\
\text { their families would improve the } \\
\text { attitude of the medical staff towards } \\
\text { them. } \\
\text { A third of the patients expressed } \\
\text { they would like more than one FM } \\
\text { to attend the ward rounds. } \\
\text { Staff members who did ward rounds } \\
\text { with FMs expressed a more positive } \\
\text { attitude towards their presence than } \\
\text { those who did not. However, the } \\
\text { staff's attitude towards the presence } \\
\text { of FMs in ward rounds was mostly } \\
\text { positive. }\end{array}$ \\
\hline
\end{tabular}




\begin{tabular}{|c|c|c|c|c|c|}
\hline \multicolumn{6}{|c|}{$\begin{array}{l}\text { Studies identified and included through grey literature } \\
\text { research }\end{array}$} \\
\hline $\begin{array}{l}16] \\
\text { Shin et al., } 2013 \\
\text { Korea }\end{array}$ & $\begin{array}{l}\text { Design: Cross- } \\
\text { sectional study } \\
\text { Method: Quantitative }\end{array}$ & $\begin{array}{l}\text { Sample: } 990 \text { patient- } \\
\text { caregiver dyads } \\
\text { Age: Patients: mean } \\
\text { age= 59.5, SD = } 12.9 \\
\text { Caregiver: mean age = } \\
\text { 50.0, SD= } 14.5 \\
\text { Gender: Patients: } 46.4 \% \\
\text { are men } \\
\text { Caregivers: } 37,9 \% \text { are } \\
\text { men } \\
\text { Close others } \\
\text { characteristics: } 54,9 \% \\
\text { of spouses, } 18.7 \% \text { of } \\
\text { children, } 14.7 \% \text { of } \\
\text { parents, } 4.7 \% \text { of } \\
\text { son/daughter in law, } \\
\text { 4.2\% of siblings, } 1.4 \% \\
\text { of others and } 1.2 \% \text { of } \\
\text { missing data } \\
\text { Recruitment: The } \\
\text { National Cancer Center } \\
\text { and the nine } \\
\text { government-designated } \\
\text { Regional Cancer Centers } \\
\text { in Korea } \\
\text { Discipline: Oncology } \\
\text { (diverse cancers) } \\
\text { Choice: Treatment }\end{array}$ & $\begin{array}{l}\text { The place } \\
\text { of family in } \\
\text { treatment } \\
\text { decision is: } \\
\text { A main } \\
\text { objective of } \\
\text { the study }\end{array}$ & $\begin{array}{l}\text { Questionnaires: } \\
\text { - } \text { Questions about the } \\
\text { preferences of the } \\
\text { participants } \\
\text { regarding the } \\
\text { degree of family } \\
\text { involvement in } \\
\text { treatment decision- } \\
\text { making. } \\
\text { - The Cancer } \\
\text { Communication } \\
\text { Assessment Tool } \\
\text { for Patients and } \\
\text { Families (CCAT- } \\
\text { PF) (18 items) }\end{array}$ & $\begin{array}{l}\text { Most patients and half of the } \\
\text { caregivers thought that the patients } \\
\text { should take the lead in treatment } \\
\text { decisions with their families input, } \\
\text { whereas a smaller proportion of the } \\
\text { patients and caregivers preferred the } \\
\text { families to lead with the patients' } \\
\text { input. Very few participants } \\
\text { expressed a preference/experience of } \\
\text { unilateral decision-making. } \\
\text { Finally, there were no significant } \\
\text { differences between treatment } \\
\text { decision-making preferences and } \\
\text { experiences for the patients or } \\
\text { caregivers. } \\
\text { The more educated the patients the } \\
\text { more they wished for their families } \\
\text { not to get involved. } \\
\text { Different factors were associated } \\
\text { with the concordance between the } \\
\text { caregivers' and the patients' } \\
\text { opinions: older patient age, higher } \\
\text { caregiver education and caregiver- } \\
\text { patient relationship (adult child- } \\
\text { patient dyads were less concordant } \\
\text { than spouse-patient dyads). } \\
\text { Conversely, poor family } \\
\text { communication was associated with } \\
\text { poor treatment decision-making }\end{array}$ \\
\hline
\end{tabular}




\begin{tabular}{|c|c|c|c|c|c|}
\hline & & & & & concordance. \\
\hline $\begin{array}{l}{[29]} \\
\text { Harwood and } \\
\text { Clark, } 2014 \\
\text { UK }\end{array}$ & $\begin{array}{l}\text { Design: Cross- } \\
\text { sectional and } \\
\text { retrospective study } \\
\text { Method: Qualitative }\end{array}$ & $\begin{array}{l}\text { Sample: } 13 \text { patients } \\
\text { Age: mean age= } 74.3 \text {, } \\
\text { ranging from } 65 \text { to } 83 \\
\text { Gender: } 6(46 \%) \\
\text { women } \\
\text { Close others } \\
\text { characteristics: No } \\
\text { close others were } \\
\text { included in this study } \\
\text { Recruitment: } \\
\text { Multidisciplinary CKD } \\
\text { clinic } \\
\text { Discipline: Nephrology } \\
\text { (CKD) } \\
\text { Choice: Dialysis } \\
\text { modality }\end{array}$ & $\begin{array}{l}\text { The place } \\
\text { of family in } \\
\text { treatment } \\
\text { decision is: } \\
\text { Not a main } \\
\text { objective of } \\
\text { the study }\end{array}$ & $\begin{array}{l}\text { Semi-structured } \\
\text { interview: } \\
\text { Realistic interviewing, } \\
\text { theory-driven data } \\
\text { collection. }\end{array}$ & $\begin{array}{l}\text { The patients described that they did } \\
\text { not want to be a burden for their } \\
\text { children. } \\
\text { The success of home dialysis was } \\
\text { highly dependent on money, support } \\
\text { (physical) and the presence/absence } \\
\text { of someone at home to help. } \\
\text { The men were less likely to look for } \\
\text { information on dialysis and more } \\
\text { likely to delay their decision. For } \\
\text { some of the men, their wives were } \\
\text { the ones seeking out information. } \\
\text { The dialysis decision was shared } \\
\text { with the partners or other FMs. } \\
\text { Thus, these individuals also had to } \\
\text { obtain information about the } \\
\text { different treatments available. They } \\
\text { often helped reinforce and clarify } \\
\text { the information and advice given by } \\
\text { the HCP. } \\
\text { In the language used, "I" was often } \\
\text { replaced by "We" regarding } \\
\text { decision-making. }\end{array}$ \\
\hline $\begin{array}{l}{[31]} \\
\text { Hubbard et al., } \\
2009 \\
\text { Scotland }\end{array}$ & $\begin{array}{l}\text { Design: Cross- } \\
\text { sectional, } \\
\text { retrospective and } \\
\text { longitudinal study } \\
\text { Method: Qualitative }\end{array}$ & $\begin{array}{l}\text { Sample: } 43 \text { patients and } \\
43 \text { carers } \\
\text { Age: NS } \\
\text { Gender: NS } \\
\text { Close others } \\
\text { characteristics: NS } \\
\text { Recruitment: } \\
\text { Outpatient clinics in }\end{array}$ & $\begin{array}{l}\text { The place } \\
\text { of family in } \\
\text { treatment } \\
\text { decision is: } \\
\text { A main } \\
\text { objective of } \\
\text { the study }\end{array}$ & $\begin{array}{l}\text { Semi-structured } \\
\text { interviews: } \\
\text { They were conducted } \\
\text { close to key periods: } \\
\text { Diagnosis, treatment } \\
\text { and follow-up. } \\
\text { The interviews focused } \\
\text { on experiences of the }\end{array}$ & $\begin{array}{l}\text { The carers as a means to get } \\
\text { information } \\
\text { Some carers could assume a } \\
\text { dominant role (vs. passive role for } \\
\text { the patients) in understanding } \\
\text { medical information, especially } \\
\text { when the patients found it difficult } \\
\text { to process information. FMs could }\end{array}$ \\
\hline
\end{tabular}




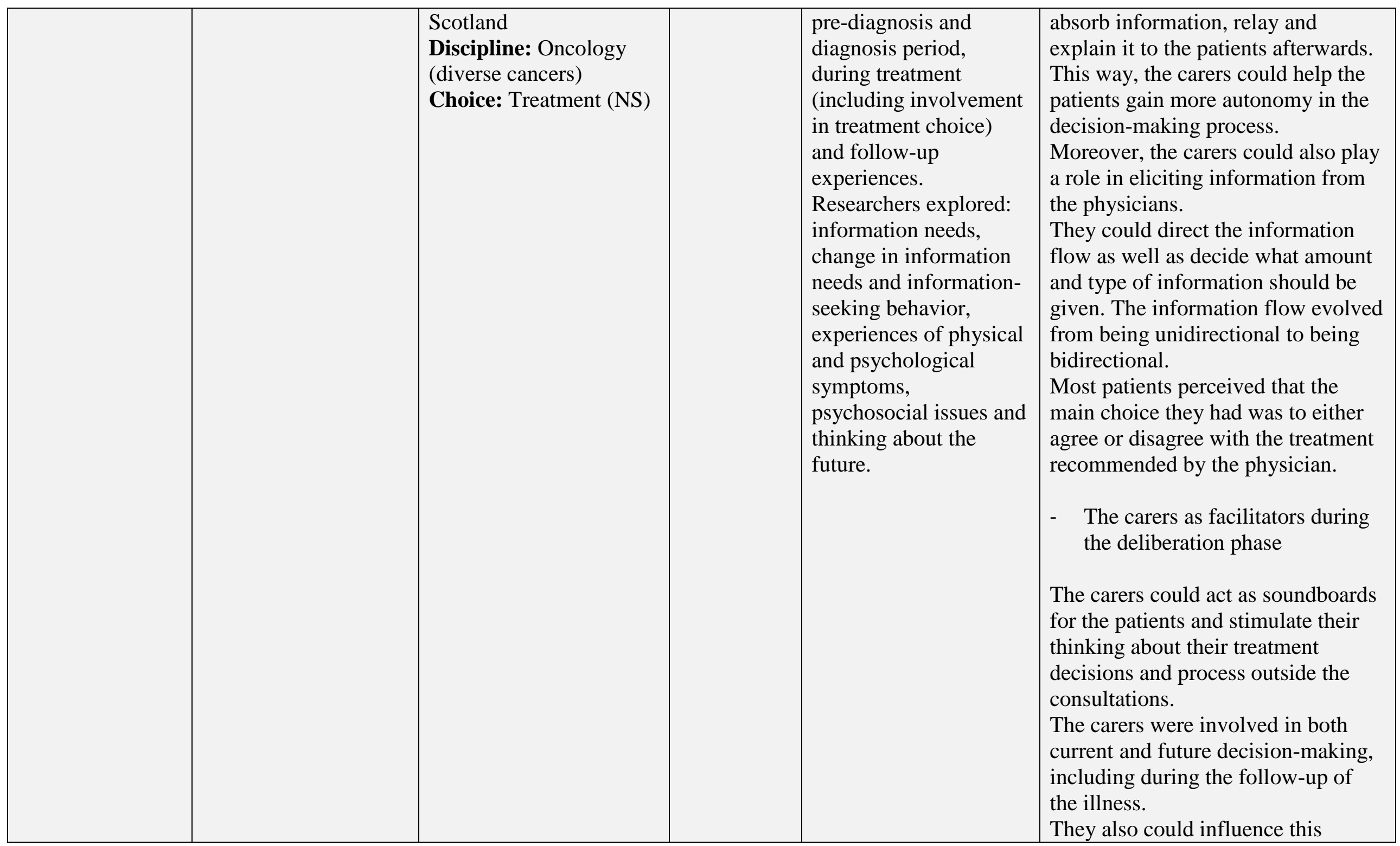




\begin{tabular}{|c|c|c|c|c|c|}
\hline & & & & & $\begin{array}{l}\text { process by deciding which physician } \\
\text { to see. } \\
\text { Failure to involve the families could } \\
\text { be upsetting for both the patients and } \\
\text { the carers. This could lead the } \\
\text { patients to feel uninformed and } \\
\text { prevent the carers from being able to } \\
\text { be supportive. }\end{array}$ \\
\hline $\begin{array}{l}{[35]} \\
\text { Krieger et al., } \\
2015 \\
\text { USA }\end{array}$ & $\begin{array}{l}\text { Design: Cross- } \\
\text { sectional and } \\
\text { retrospective study } \\
\text { Method: Qualitative }\end{array}$ & $\begin{array}{l}\text { Sample: } 58 \text { caregivers } \\
\text { Age: mean age= } 55.1 \text {, } \\
\text { SD= } 15 \\
\text { Gender: } 65.5 \% \text { were } \\
\text { women } \\
\text { Close others } \\
\text { characteristics: } 41.4 \% \\
\text { were spouses and } 29.3 \% \\
\text { were adult children } \\
\text { Recruitment: City of } \\
\text { Appalachia, Ohio. } \\
\text { Referred by patients } \\
\text { participating in another } \\
\text { study. } \\
\text { Discipline: Oncology } \\
\text { Choice: Treatment }\end{array}$ & $\begin{array}{l}\text { The place } \\
\text { of family in } \\
\text { treatment } \\
\text { decision is: } \\
\text { A main } \\
\text { objective of } \\
\text { the study }\end{array}$ & $\begin{array}{l}\text { Semi-structured } \\
\text { interviews: } \\
\text { Questions and themes } \\
\text { are not specified. }\end{array}$ & $\begin{array}{l}\text { - Framing Illness as Personal } \\
\text { Identity } \\
\text { The decision-making process seen } \\
\text { through the perspective of the } \\
\text { patients' rights and responsibilities } \\
\text { (it is the patients' bodies that are } \\
\text { affected so it should be the patients' } \\
\text { decisions). } \\
\text { - Framing Illness as Relational } \\
\text { Identity } \\
\text { The cancer experience and the } \\
\text { treatment choice could lie within the } \\
\text { patient-caregiver relationship. The } \\
\text { caregivers desired to share some of } \\
\text { the rights and responsibilities } \\
\text { associated with the treatment } \\
\text { decision-making. The caregivers } \\
\text { could act as advocates for the } \\
\text { patients. } \\
\text { "We" and "our" was used to talk } \\
\text { about the illness or the choices to be } \\
\text { made. } \\
\text { - Perceiving illness identity as a } \\
\text { patient-level personal identity }\end{array}$ \\
\hline
\end{tabular}




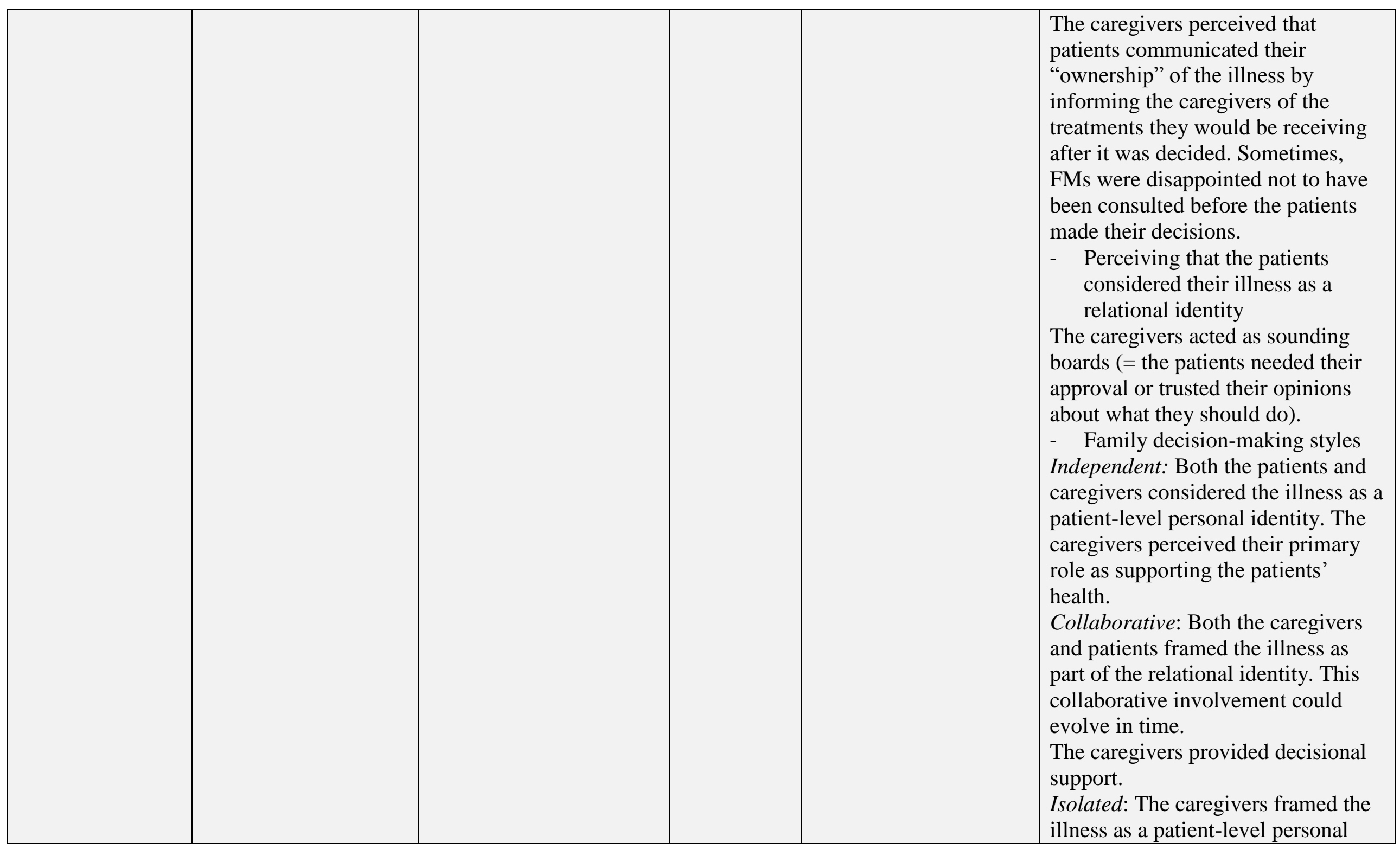




\begin{tabular}{|c|c|c|c|c|c|}
\hline & & & & & $\begin{array}{l}\text { identity but the patients framed the } \\
\text { illness and decision in relational } \\
\text { terms. The caregivers gave different } \\
\text { reasons as to why they avoided } \\
\text { participating in the treatment } \\
\text { decision-making process: } \\
\text { inconsistence with their personality, } \\
\text { lack of medical knowledge, wish to } \\
\text { stay positive... } \\
\text { Demanding: The caregivers framed } \\
\text { the illness as a relational identity but } \\
\text { the patients did not. FMs enforced } \\
\text { an active role while the patients } \\
\text { wished they did not. The caregivers } \\
\text { attempted to convince the patients to } \\
\text { take the decisions the caregivers } \\
\text { believed was correct. This approach } \\
\text { tended to pressure the patients into } \\
\text { making a specific choice. }\end{array}$ \\
\hline $\begin{array}{l}\text { [37] } \\
\text { Laidsaar-Powell } \\
\text { et al., } 2016 \\
\text { Australia }\end{array}$ & $\begin{array}{l}\text { Design: Cross- } \\
\text { sectional study } \\
\text { Method: Qualitative }\end{array}$ & $\begin{array}{l}\text { Sample: } 72 \text { patients, } 59 \\
\text { FMs and } 18 \text { oncologists } \\
\text { Age: Patients: Mean age } \\
=60,28-84 \\
\text { FMs: NS } \\
\text { Oncologists: NS } \\
\text { Gender: Patients:57\% } \\
\text { are women } \\
\text { FMs: } 63 \% \text { are women } \\
\text { Oncologists: } 39 \% \text { are } \\
\text { women } \\
\text { Close others } \\
\text { characteristics: } 38 \% \text { of }\end{array}$ & $\begin{array}{l}\text { The place } \\
\text { of family in } \\
\text { treatment } \\
\text { decision is: } \\
\text { A main } \\
\text { objective of } \\
\text { the study }\end{array}$ & $\begin{array}{l}\text { Audio-taped } \\
\text { consultations: } \\
\text { KINcode: coding } \\
\text { system that investigates } \\
\text { communication and } \\
\text { decision-making } \\
\text { behaviors of FMs and } \\
\text { family-relevant } \\
\text { behaviors of the } \\
\text { patients and the } \\
\text { oncologists. } \\
\text { It was established on a } \\
\text { list of family and }\end{array}$ & $\begin{array}{l}\text { The consultation was defined by } \\
\text { four different stages: history taking, } \\
\text { information exchange, deliberation } \\
\text { and decision-making. } \\
\text { - Family roles in the consultation: } \\
\text { Supportive role ( } 40 \% \text { of FMs during } \\
\text { the history taking phase), active role } \\
\text { ( } 46 \% \text { of FMs during the information } \\
\text { exchange stage), passive role ( } 42 \% \\
\text { of the FMs during the deliberation } \\
\text { and decision-making phase) and } \\
\text { dominant role ( } 10 \% \text { of the FMs }\end{array}$ \\
\hline
\end{tabular}




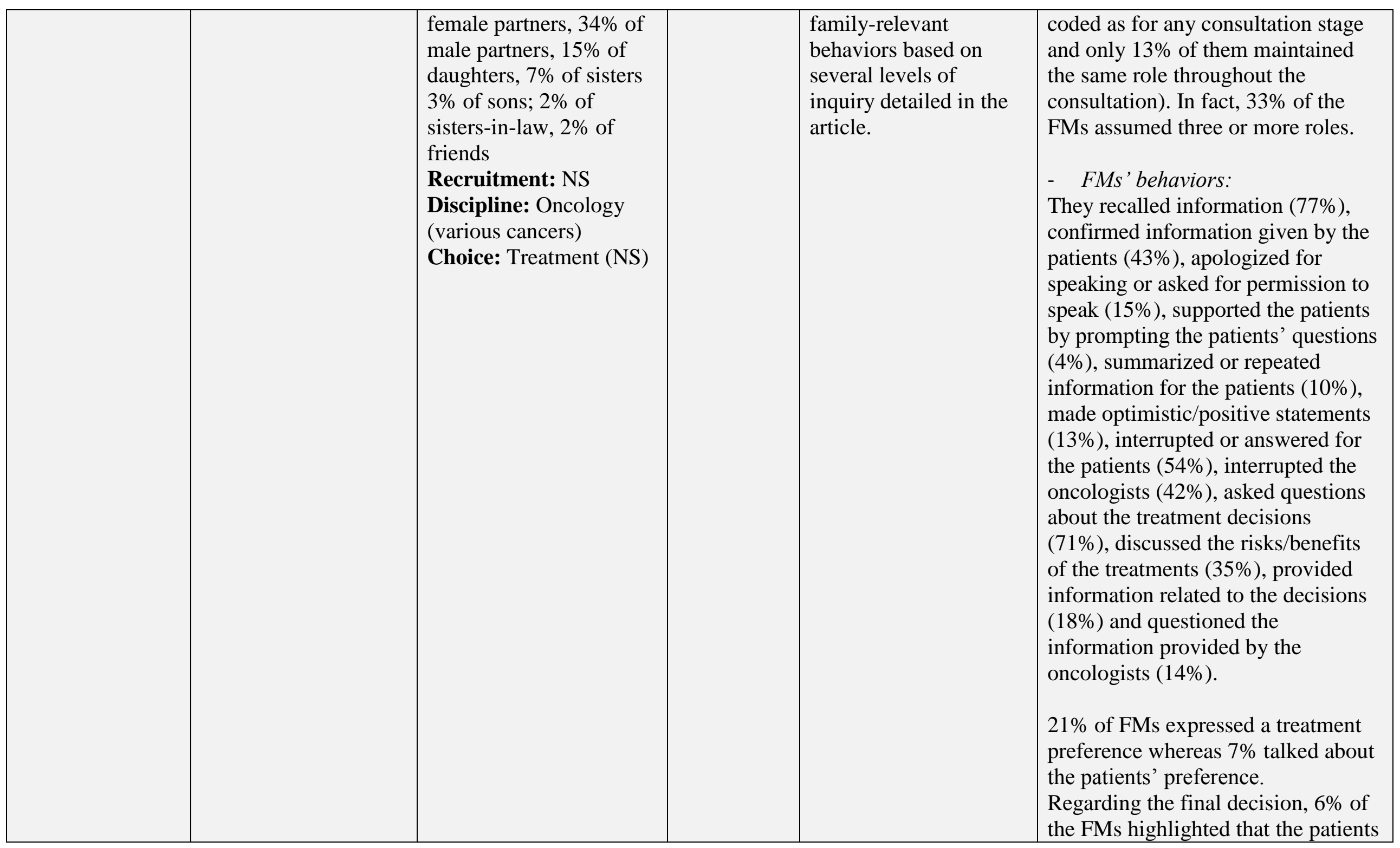




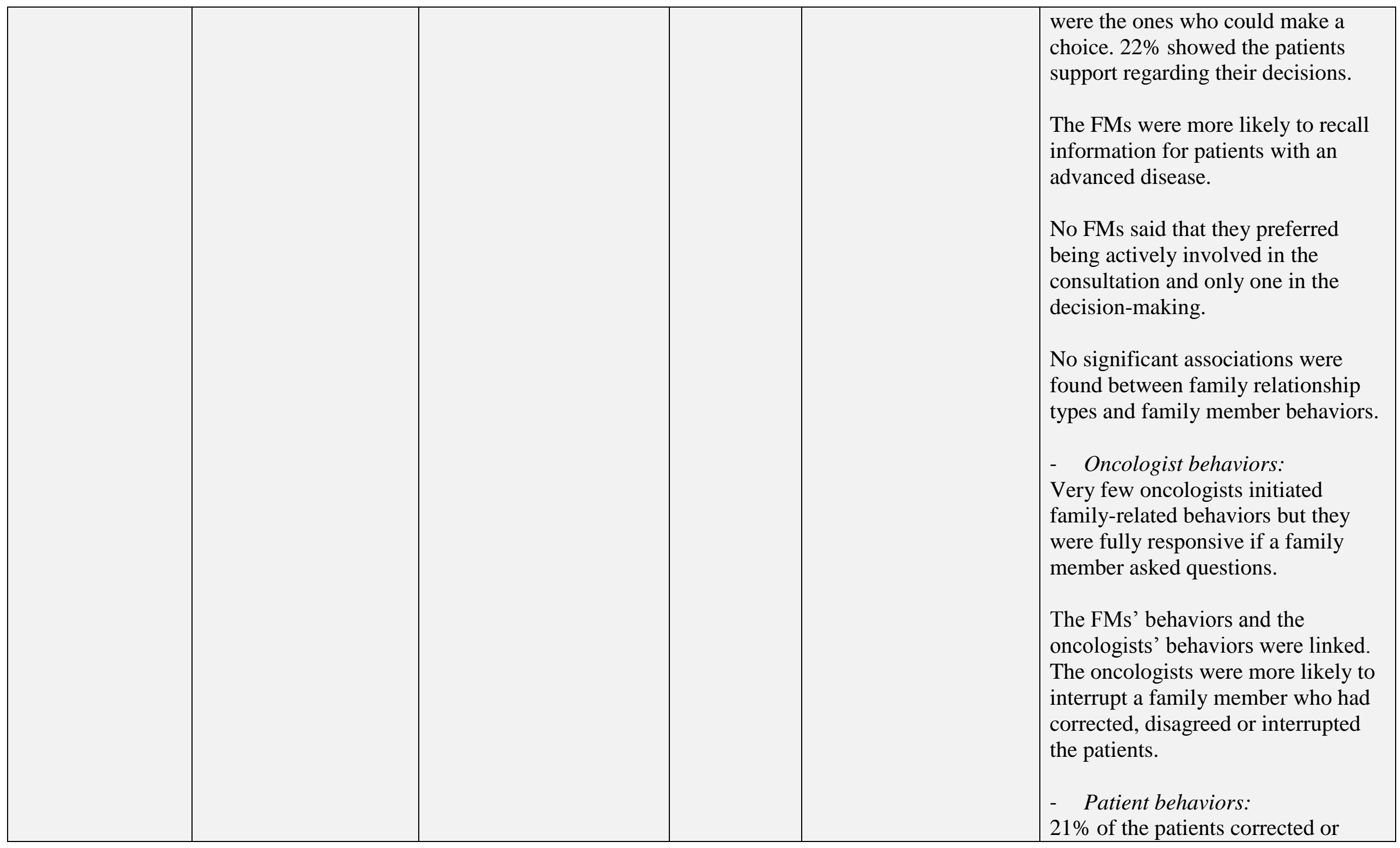




\begin{tabular}{|c|c|c|c|c|c|}
\hline & & & & & $\begin{array}{l}\text { disagreed with their FMs. } 31 \% \text { of } \\
\text { the patients interrupted their FMs at } \\
\text { least once. No patients expressed } \\
\text { any preferences for their families to } \\
\text { be involved, in two consultations } \\
\text { however the patients indicated a } \\
\text { desire for their FMs to stop talking } \\
\text { or become more passive. No patient } \\
\text { deferred their decision to their } \\
\text { family member. }\end{array}$ \\
\hline $\begin{array}{l}\text { [38] } \\
\text { Laidsaar-Powell } \\
\text { et al., } 2016 \\
\text { Australia }\end{array}$ & $\begin{array}{l}\text { Design: Cross- } \\
\text { sectional and } \\
\text { retrospective study } \\
\text { Method: Qualitative }\end{array}$ & $\begin{array}{l}\text { Sample: } 30 \text { patients, } 33 \\
\text { FMs (16 matched } \\
\text { patient-family member } \\
\text { pairs) } \\
\text { Age: Patients: mean age } \\
=56 \text {, ranging from } 30 \text { to } \\
80 \\
\text { Family/friends: mean } \\
\text { age = 54, ranging from } \\
28 \text { to } 81 \\
\text { Gender: Patients: } 50 \% \\
\text { are men } \\
\text { FMs: } 39 \% \text { are men } \\
\text { Close others } \\
\text { characteristics: } 45 \% \text { of } \\
\text { female partners, } 30 \% \text { of } \\
\text { male partners, } 12 \% \text { of } \\
\text { others, } 6 \% \text { of sons, } 3 \% \\
\text { of daughters (1), } 3 \% \text { of } \\
\text { sisters (1) } \\
\text { Recruitment: An } \\
\text { oncology clinic in a }\end{array}$ & $\begin{array}{l}\text { The place } \\
\text { of family in } \\
\text { treatment } \\
\text { decision is: } \\
\text { A main } \\
\text { objective of } \\
\text { the study }\end{array}$ & $\begin{array}{l}\text { Semi-structured } \\
\text { interviews: } \\
\text { The participants were } \\
\text { asked to discuss in } \\
\text { detail the role of their } \\
\text { families over the course } \\
\text { of the patients' illness } \\
\text { and were prompted to } \\
\text { provide specific } \\
\text { information about the } \\
\text { family involvement at } \\
\text { important points in the } \\
\text { illness trajectory. }\end{array}$ & $\begin{array}{l}\text { Most participants explained that one } \\
\text { "key" family member consistently } \\
\text { attended most consultations and was } \\
\text { usually the most involved in the } \\
\text { discussions about treatment } \\
\text { decisions. } \\
\text { Three main themes emerged: } \\
\text { - "Family behaviors [...]" } \\
\text { Before the consultation: the families } \\
\text { influenced the choice of oncologist } \\
\text { or treatment center. } \\
\text { Information exchange stage: they } \\
\text { provided informational assistance to } \\
\text { both the patients and clinicians (e.g., } \\
\text { listening, remembering, providing } \\
\text { information). } \\
\text { Deliberation stage: sounding board, } \\
\text { they supported the patients' wishes } \\
\text { and preferences. Few dominated the } \\
\text { deliberation or expressed their } \\
\text { preferences. }\end{array}$ \\
\hline
\end{tabular}




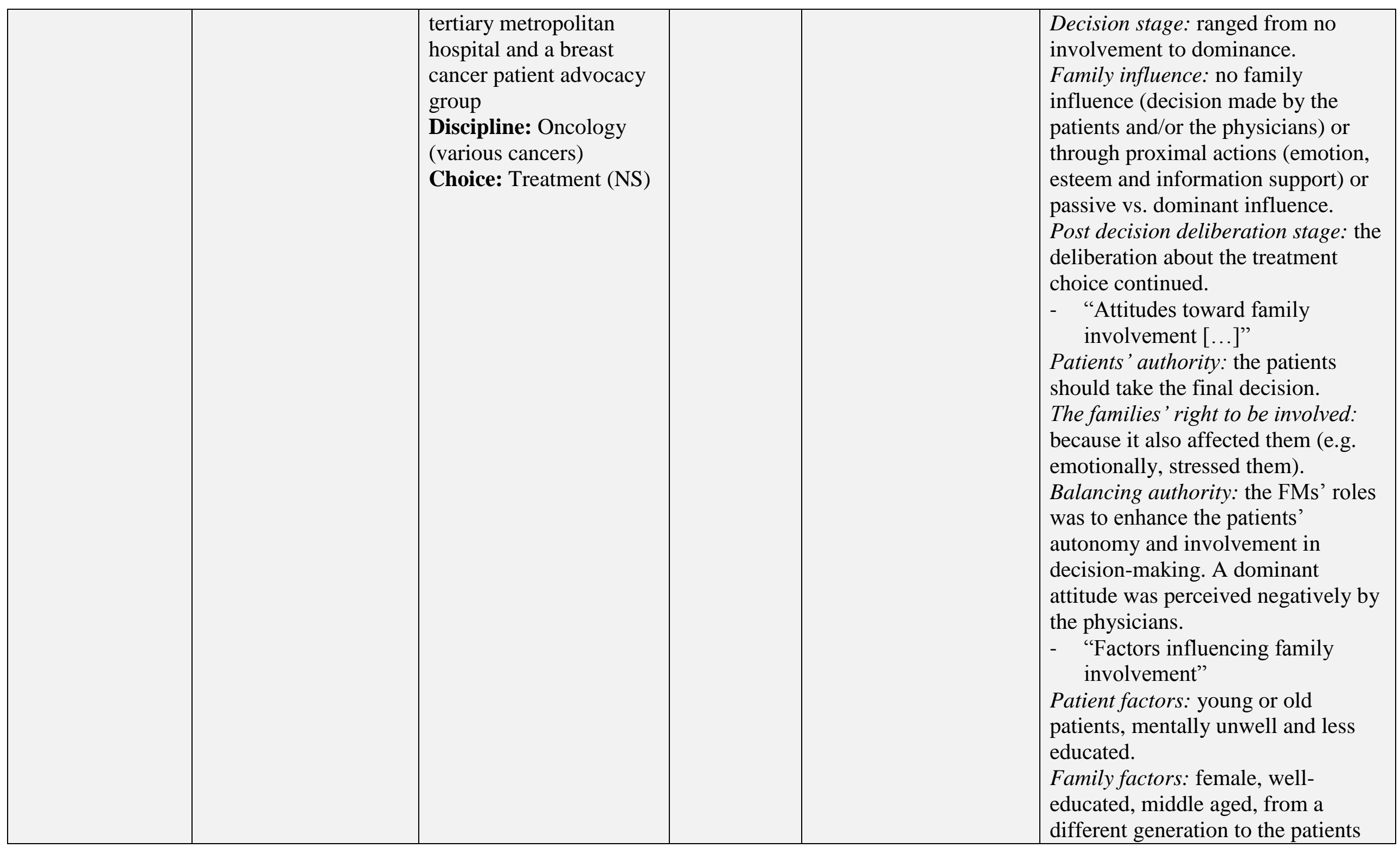




\begin{tabular}{|c|c|c|c|c|c|}
\hline & & & & & $\begin{array}{l}\text { and with medical knowledge. } \\
\text { Cultural factors: culture and } \\
\text { language. } \\
\text { Relationship factors: strong and } \\
\text { close relationship with the patients. } \\
\text { Decision factors: important or } \\
\text { complex decisions to make. }\end{array}$ \\
\hline $\begin{array}{l}\text { [40] } \\
\text { Lee and Tish } \\
\text { Knobf, } 2015 \\
\text { USA }\end{array}$ & $\begin{array}{l}\text { Design: Cross- } \\
\text { sectional and } \\
\text { retrospective study } \\
\text { Method: Qualitative }\end{array}$ & $\begin{array}{l}\text { Sample: } 123 \text { patients } \\
\text { Age: Mean age }=48.7, \\
18.7 \% \text { are women under } \\
40,42.3 \% \text { aged between } \\
40 \text { and } 50,25.2 \% \text { aged } \\
\text { between } 50 \text { and } 60 \text { and } \\
13.8 \% \text { are women over } \\
60 \\
\text { Gender: All women } \\
\text { Close others } \\
\text { characteristics: No } \\
\text { close others were } \\
\text { included in this study } \\
\text { Recruitment: The } \\
\text { greater New York City } \\
\text { area } \\
\text { Discipline: Oncology } \\
\text { (Breast Cancer) } \\
\text { Choice: Primary } \\
\text { treatment }\end{array}$ & 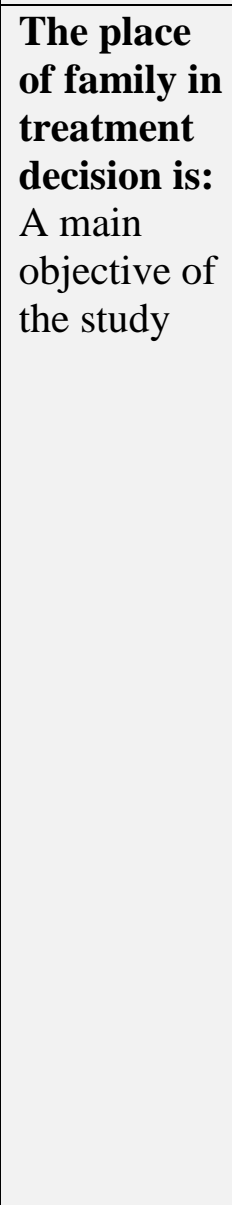 & $\begin{array}{l}\text { Semi-structured } \\
\text { interviews: } \\
\text { - } \quad \text { Description of how } \\
\text { FMs were involved } \\
\text { in their primary } \\
\text { treatment decision } \\
\text { making for breast } \\
\text { cancer } \\
\text { - Examples of the } \\
\text { type of involvement } \\
\text { - Discussion on } \\
\text { family involvement } \\
\text { and its influence on } \\
\text { the women's } \\
\text { decision and the } \\
\text { overall decision } \\
\text { making process. } \\
\text { Content analysis and } \\
\text { inductive coding. }\end{array}$ & $\begin{array}{l}\text { Family involvement in treatment } \\
\text { decision-making could be divided in } \\
\text { different categories: } \\
\text { - Gathering information: } \\
\text { The FMs searched, organized and } \\
\text { helped analyze the risks/benefits of } \\
\text { the options available. } \\
\text { - Being there: } \\
\text { The FMs' companionship was } \\
\text { extremely valuable for the patients. } \\
\text { Not all women received the support } \\
\text { they wanted from their families } \\
\text { during the decision-making process. } \\
\text { This was a barrier and a source of } \\
\text { worry for these women. } \\
\text { - Navigating the Health Care } \\
\text { System: } \\
\text { Limited English fluency was a } \\
\text { significant barrier to accessing care } \\
\text { and communicating with the } \\
\text { clinician (even with a translator). } \\
\text { FMs also helped with the } \\
\text { administrative work. } \\
\text { Families and friends helped them } \\
\text { look for second opinions and buffer }\end{array}$ \\
\hline
\end{tabular}




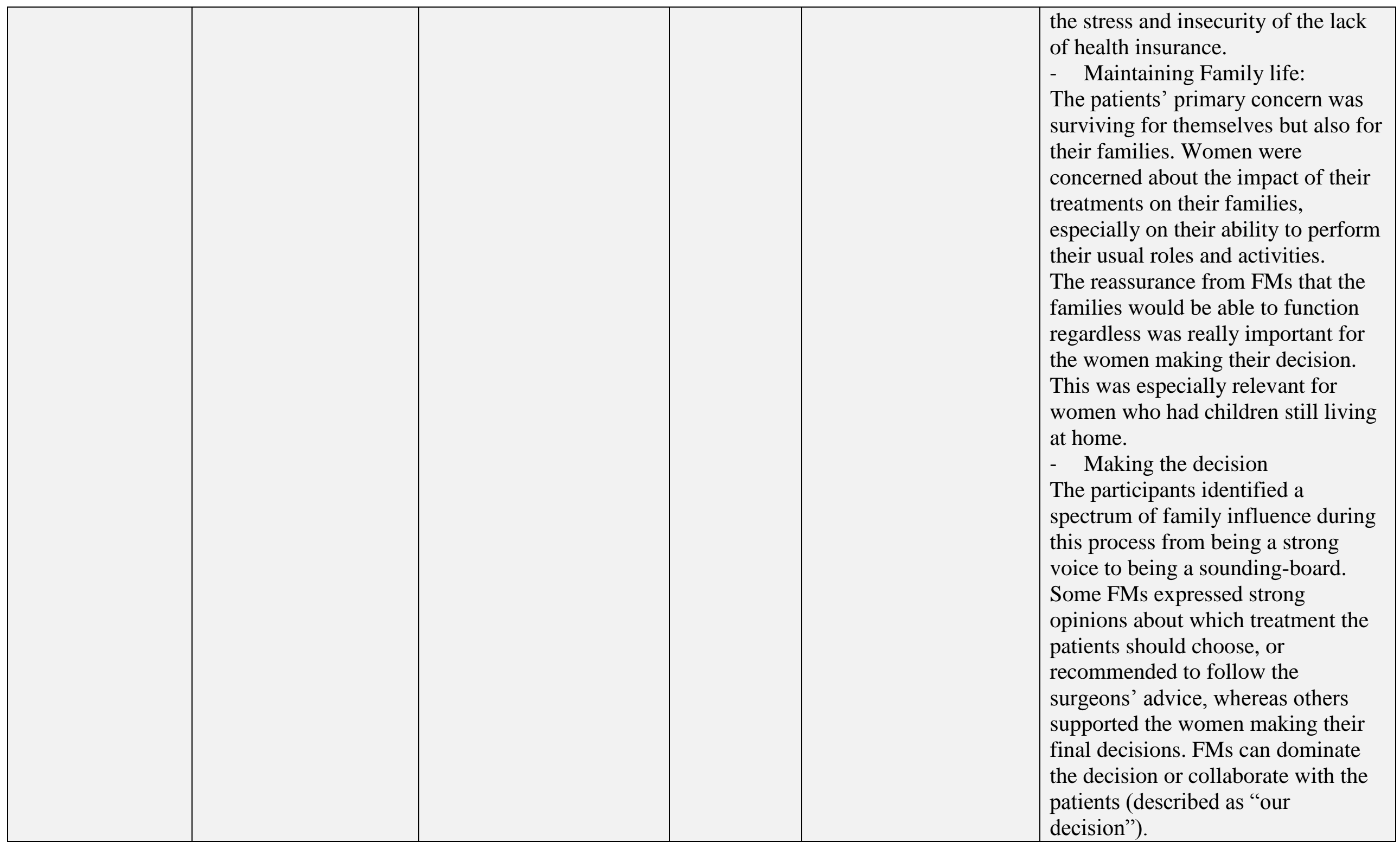




\begin{tabular}{|c|c|c|c|c|c|}
\hline $\begin{array}{l}51] \\
\text { Clayman et al., } \\
2005 \\
\text { USA }\end{array}$ & $\begin{array}{l}\text { Design: Cross- } \\
\text { sectional study } \\
\text { Method: } \\
\text { Observational } \\
\text { (videotapes) }\end{array}$ & $\begin{array}{l}\text { Sample: } 93 \text { patients and } \\
92 \text { companions } \\
\text { Age: Patients: mean } \\
\text { age }=78.5 \text {, ranging from } \\
65 \text { to } 85, \mathrm{SD}=7.2 \\
\text { Close others: mean age= } \\
60.7 \text {, ranging from } 25 \text { to } \\
\text { 90, SD=14.8 } \\
\text { Gender: Patients: } 28 \% \\
\text { are men } \\
\text { Close others: } 34 \% \text { are } \\
\text { men } \\
\text { Close others } \\
\text { characteristics: } 46 \% \text { of } \\
\text { partners, } 36 \% \text { of adult } \\
\text { children and } 16 \% \text { of } \\
\text { other relatives and } \\
\text { friends } \\
\text { Recruitment: Three } \\
\text { different academic } \\
\text { medical centers in } \\
\text { Missouri, New Mexico } \\
\text { and Ohio } \\
\text { Discipline: Geriatric } \\
\text { Primary Care } \\
\text { Choice: NS }\end{array}$ & $\begin{array}{l}\text { The place } \\
\text { of family in } \\
\text { treatment } \\
\text { decision is: } \\
\text { A main } \\
\text { objective of } \\
\text { the study }\end{array}$ & $\begin{array}{l}\text { Videotaped visits: } \\
\text { Coding companion } \\
\text { behaviors: } \\
\text { Coding categories were } \\
\text { drawn from the } \\
\text { literature and the } \\
\text { viewing and analyzing } \\
\text { of the videos. } \\
\text { Behaviors were } \\
\text { categorized into two } \\
\text { broad classes: } \\
\text { autonomy-enhancing } \\
\text { behaviors and } \\
\text { autonomy-detracting. } \\
\text { Coding medical } \\
\text { decisions: } \\
\text { Medical decisions were } \\
\text { coded using an } \\
\text { adaptation of the } \\
\text { Elements of Informed } \\
\text { Decision-making. } \\
\text { Differences are listed in } \\
\text { the article. } \\
\text { Interaction Analysis: } \\
\text { The coding system } \\
\text { used was the Roter } \\
\text { Interaction Analysis } \\
\text { System (RIAS). It } \\
\text { examined each full } \\
\text { thought exchanged }\end{array}$ & $\begin{array}{l}\text { - Companions autonomy- } \\
\text { enhancing behaviors: } \\
\text { Clarifying or expanding the patients' } \\
\text { history, asking the physicians } \\
\text { questions, repeating the doctors' } \\
\text { explanations, asking the patients } \\
\text { questions, prompting the patients to } \\
\text { discuss topics and introducing } \\
\text { medical topics that were not initially } \\
\text { discussed. } \\
\text { The companions' verbal dominance } \\
\text { was positively linked to several } \\
\text { autonomy-related behaviors. } \\
\text { - The companions' autonomy- } \\
\quad \text { detracting behaviors: } \\
\text { Answering for the patients (the most } \\
\text { common), interrupting the patients } \\
\text { or discussing their own health } \\
\text { problems. } \\
\text { Most companions were engaged in } \\
\text { both positive and negative autonomy } \\
\text { behaviors. No companions engaged } \\
\text { in only autonomy-detracting } \\
\text { behaviors. } \\
\text { The companions of sicker and older } \\
\text { patients were more likely to engage } \\
\text { in facilitative behaviors compared } \\
\text { with those of healthier patients. }\end{array}$ \\
\hline
\end{tabular}




\begin{tabular}{|c|c|c|c|c|c|}
\hline & & & & $\begin{array}{l}\text { between either the } \\
\text { physician and the } \\
\text { patient or the physician } \\
\text { and the companion. } \\
\text { Companion verbal } \\
\text { dominance was } \\
\text { calculated. }\end{array}$ & $\begin{array}{l}\text { The patients were more active } \\
\text { decision makers than were their } \\
\text { companions. In one third of the } \\
\text { consultations neither the patients nor } \\
\text { the companions were active } \\
\text { decision-makers. } \\
\text { The friends and relatives other than } \\
\text { children and spouses were less likely } \\
\text { to be active in decision-making than } \\
\text { the others. } \\
\text { Facilitating patient involvement was } \\
\text { significantly related to the patients' } \\
\text { activities in decision-making. }\end{array}$ \\
\hline $\begin{array}{l}\text { [56] } \\
\text { Ohlen et al., } 2006 \\
\text { Canada }\end{array}$ & $\begin{array}{l}\text { Design: Cross- } \\
\text { sectional and } \\
\text { retrospective study } \\
\text { Method: Qualitative }\end{array}$ & $\begin{array}{l}\text { Sample: } 61 \text { cancer } \\
\text { patients and } 31 \\
\text { significant others } \\
\text { Age: Patients: mean } \\
\text { age= } 57.5, \mathrm{SD}=\mathrm{NS} \\
\text { Significant others: mean } \\
\text { age= } 53.5, \mathrm{SD}=\mathrm{NS} \\
\text { Gender: NS } \\
\text { Close others } \\
\text { characteristics: } 68 \% \text { of } \\
\text { partners, } 19 \% \text { of friends, } \\
6.5 \% \text { of adult children } \\
\text { and } 6.5 \% \text { of parents. } \\
\text { Recruitment: } \\
\text { Outpatient and } \\
\text { integrative cancer clinics } \\
\text { and cancer support } \\
\text { groups }\end{array}$ & $\begin{array}{l}\text { The place } \\
\text { of family in } \\
\text { treatment } \\
\text { decision is: } \\
\text { A main } \\
\text { objective of } \\
\text { the study }\end{array}$ & $\begin{array}{l}\text { Semi-structured } \\
\text { interviews: } \\
\text { For early stage cancer } \\
\text { patients: One in-depth } \\
\text { interview. } \\
\text { For advanced cancer } \\
\text { patients: Two shorter } \\
\text { interviews. } \\
\text { Separate interview } \\
\text { guides for early vs. } \\
\text { advanced stage cancer. } \\
\text { Questions were similar } \\
\text { but tailored to relate to } \\
\text { each group (FMs, early } \\
\text { stage cancer patients, } \\
\text { and advanced cancer }\end{array}$ & $\begin{array}{l}\text { Most of the time, the significant } \\
\text { others' involvement in decision- } \\
\text { making was initiated by the patients } \\
\text { but for some significant others, their } \\
\text { involvement was self-initiated when } \\
\text { they perceived that it was an } \\
\text { important way of offering support } \\
\text { for the patients. The beliefs on the } \\
\text { reliability of complementary and } \\
\text { alternative medicines were an } \\
\text { important influence on the } \\
\text { significant others' involvement. It } \\
\text { could result in disagreements with } \\
\text { the patients and tensions. } \\
\text { Four main types of decisional } \\
\text { involvement: } \\
\text { - Creating a safe place for the }\end{array}$ \\
\hline
\end{tabular}




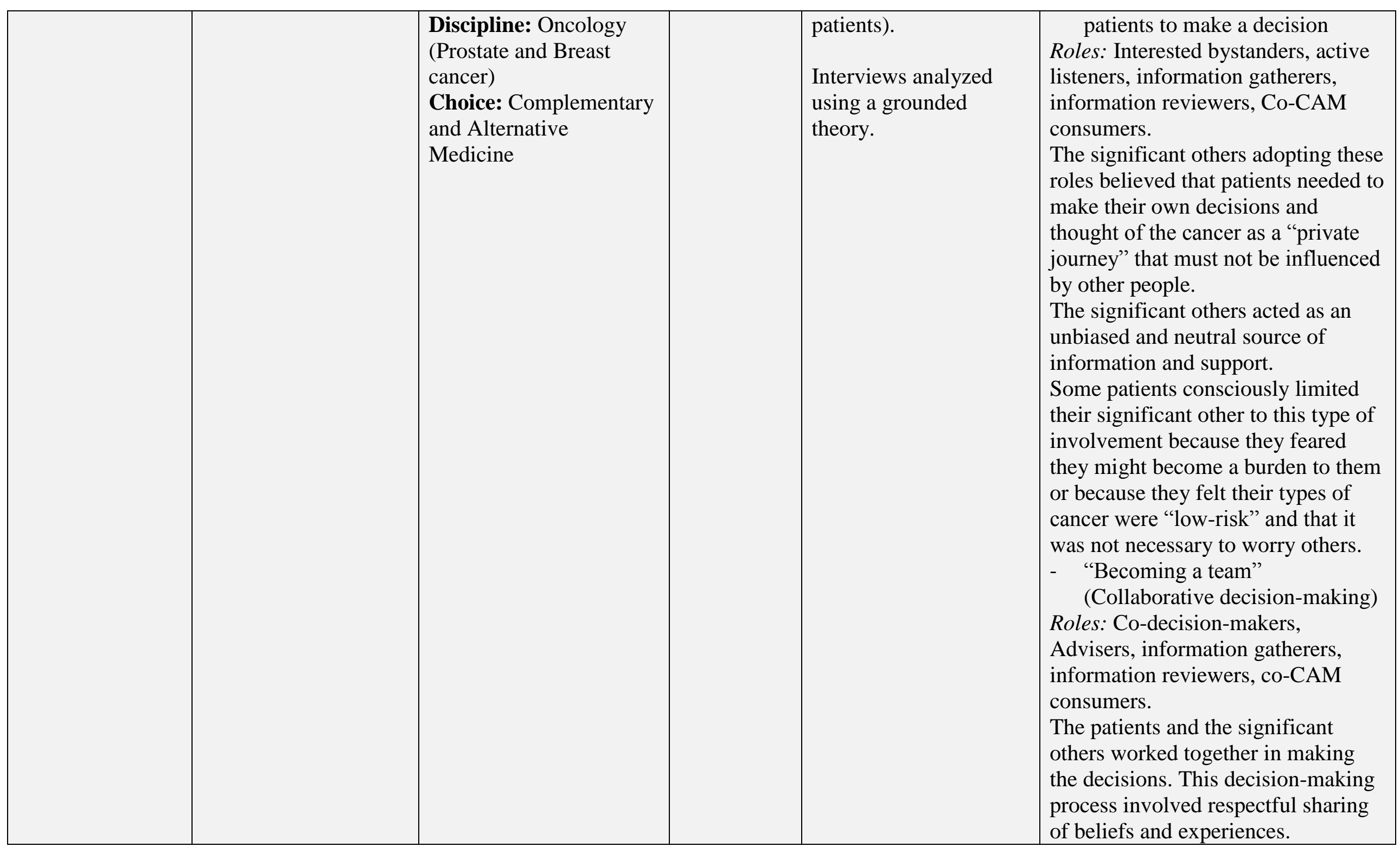




\begin{tabular}{|c|c|c|c|c|c|}
\hline & & & & & $\begin{array}{l}\text { The patient reported that this kind of } \\
\text { involvement strengthened the } \\
\text { relationship with their significant } \\
\text { others, reduced their anxiety about } \\
\text { the decisions and improved the } \\
\text { quality of the decision-making } \\
\text { process. } \\
\text { The patients still described the } \\
\text { complementary and alternative } \\
\text { medicine decision as their choice. } \\
\text { - Moving the patients towards a } \\
\quad \text { decision } \\
\text { Roles: Persuaders, advisers, } \\
\text { information gatherers, information } \\
\text { reviewers, co-CAM consumers. } \\
\text { This type of involvement refers to } \\
\text { when the significant others } \\
\text { attempted to directly influence the } \\
\text { patients' decisions (e.g., push the } \\
\text { patients to use a certain treatment). } \\
\text { The significant others' influence } \\
\text { ranged from gentle suggestions to } \\
\text { direct recommendations and } \\
\text { powerful persuasive tactics. } \\
\text { - Making the decision for the } \\
\text { patients } \\
\text { Roles: Directors, information } \\
\text { gatherers, information reviewers, co- } \\
\text { CAM consumers. }\end{array}$ \\
\hline $\begin{array}{l}60] \\
\text { Tong et al., } 2009\end{array}$ & $\begin{array}{l}\text { Design: Cross- } \\
\text { sectional study } \\
\text { Method: Qualitative }\end{array}$ & $\begin{array}{l}\text { Sample: } 63 \text { patients } \\
\text { Age: mean age }=52.3 \text {, } \\
\text { ranging from } 20 \text { to } 78\end{array}$ & $\begin{array}{l}\text { The place } \\
\text { of family in } \\
\text { treatment }\end{array}$ & $\begin{array}{l}\text { Focus Groups: } \\
9 \text { focus groups either in } \\
\text { stage } 1-5, \text { no dialysis, }\end{array}$ & $\begin{array}{l}\text { The participants who underwent or } \\
\text { thought about living transplants } \\
\text { described feeling excessive pressure }\end{array}$ \\
\hline
\end{tabular}




\begin{tabular}{|c|c|c|c|c|}
\hline Australia & $\begin{array}{l}\text { Gender: } 49 \% \text { were men } \\
\text { Close others } \\
\text { characteristics: No } \\
\text { close others were } \\
\text { included in this study } \\
\text { Recruitment: Princess } \\
\text { Alexandra Hospital, } \\
\text { Queensland; Royal } \\
\text { Prince Albert Hospital, } \\
\text { Sydney; Westmead } \\
\text { Hospital, Westmead; } \\
\text { Royal Melbourne } \\
\text { Hospital, Melbourne } \\
\text { Discipline: Nephrology } \\
\text { (Chronic Kidney } \\
\text { Disease) } \\
\text { Choice: Hemodialysis, } \\
\text { Peritoneal dialysis and } \\
\text { Transplantation }\end{array}$ & $\begin{array}{l}\text { decision is: } \\
\text { Not a main } \\
\text { objective of } \\
\text { the study }\end{array}$ & $\begin{array}{l}\text { in stage } 5 \text { and currently } \\
\text { undergoing } \\
\text { hemodialysis or } \\
\text { peritoneal dialysis or } \\
\text { stage 1-4 and stage } 5 \\
\text { and living with a } \\
\text { transplant. } \\
\text { Four questions: } \\
\text { - "I have no direct } \\
\text { experience of CKD, } \\
\text { how would you } \\
\text { explain to someone } \\
\text { like me what it's } \\
\text { like to live with } \\
\text { CKD?" } \\
\text { "What helps you to } \\
\text { live with CKD?" } \\
\text { "What makes it } \\
\text { harder to live with } \\
\text { CKD?" } \\
\text { "What solutions } \\
\text { have you found to } \\
\text { deal with these } \\
\text { problems, and is } \\
\text { there anything else } \\
\text { you can think of that } \\
\text { would make life } \\
\text { better for people } \\
\text { with CKD?" }\end{array}$ & $\begin{array}{l}\text { from donors, physicians, family } \\
\text { expectations and self-reproach for } \\
\text { putting another person at risk. } \\
\text { At the same time, some believed it } \\
\text { was wrong to refuse the offer of a } \\
\text { kidney if one of their FMs wanted to } \\
\text { donate. } \\
\text { The decision to accept a kidney was } \\
\text { predominantly based on the nature } \\
\text { of the relationship the patients had } \\
\text { with their potential donors. } \\
\text { The participants who underwent } \\
\text { dialysis made the decision regarding } \\
\text { the modality based on family and } \\
\text { lifestyle impact. }\end{array}$ \\
\hline
\end{tabular}

